\title{
Geochemical and Isotopic Composition of Ground Water, with Emphasis on Sources of Sulfate, in the Upper Floridan Aquifer and Intermediate Aquifer System in Southwest Florida
}

By Laura A. Sacks and Ann B. Tihansky

U.S. GEOLOGICAL SURVEY

Water-Resources Investigations Report 96-4146

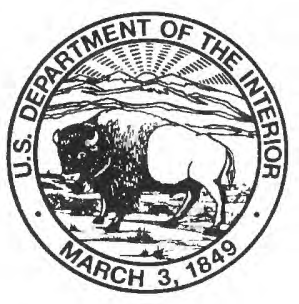




\title{
U.S. DEPARTMENT OF THE INTERIOR BRUCE BABBITT, Secretary
}

\author{
U.S. GEOLOGICAL SURVEY \\ Gordon P. Eaton, Director
}

Any use of trade, product, or firm names in this publication is for descriptive purposes only and does not imply endorsement by the U.S. Geological Survey.

For additional information write to:

Copies of this report can be purchased from:

District Chief

U.S. Geological Survey

227 North Bronough Street, Suite 3015

Tallahassee, Florida 32301
U.S. Geological Survey

Branch of Information Center

Box 25286

Denver, CO 80225-0286 


\section{CONTENTS}

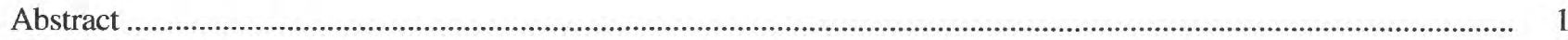

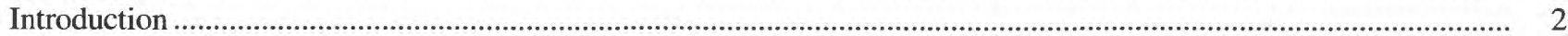

Purpose and Scope

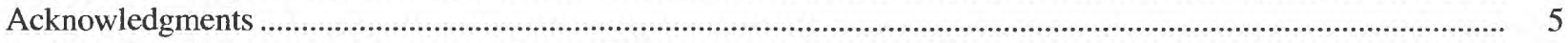

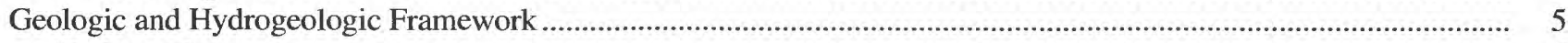

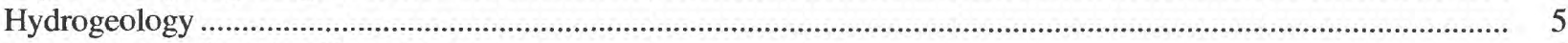

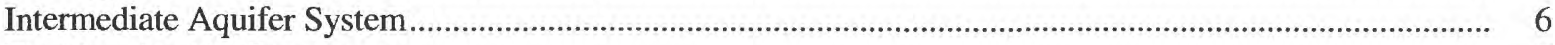

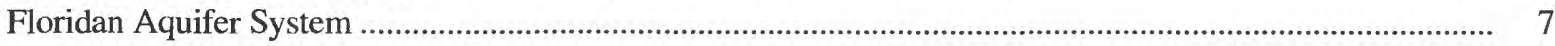

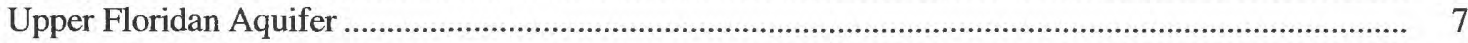

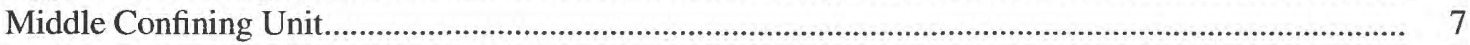

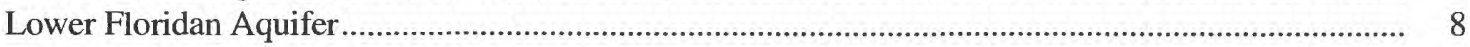

Ground-Water Flow and Circulation ................................................................................................ 8

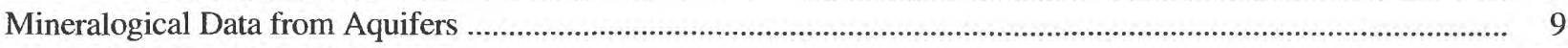

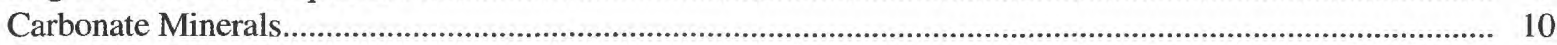

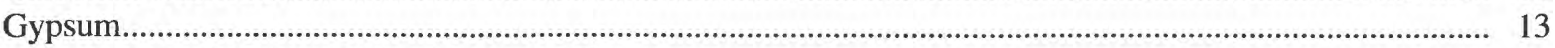

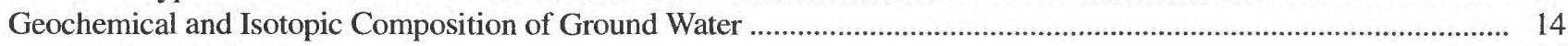

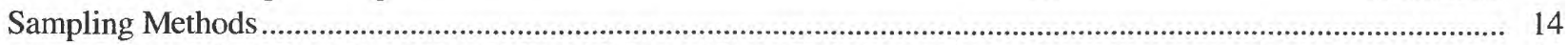

Determining Flow Zones for Wells with Large Open Hole Intervals........................................................ 15

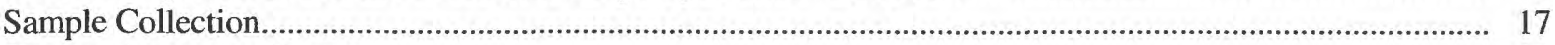

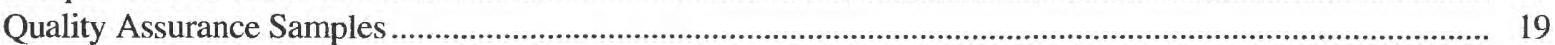

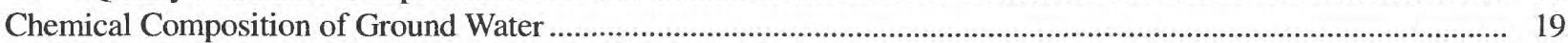

Saturation State of Water with Respect to Minerals ..................................................................................... 23

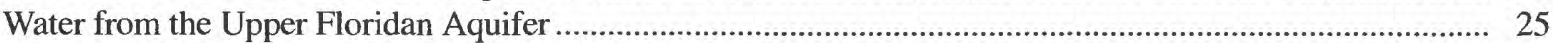

Brackish and Saline Ground Waters in Coastal Areas...................................................................... 27

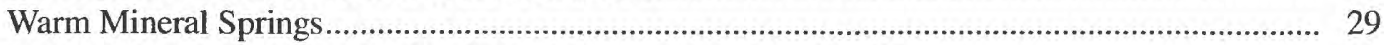

Evaluating Water from the Middle Confining Unit as a Source of Sulfate ........................................... 30

Water from the Intermediate Aquifer System............................................................................................ 31

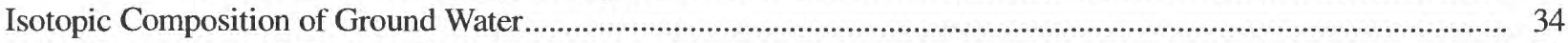

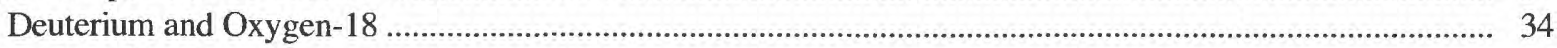

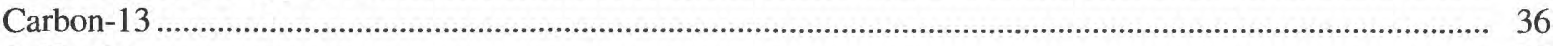

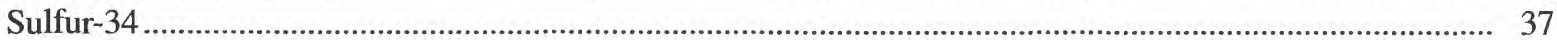

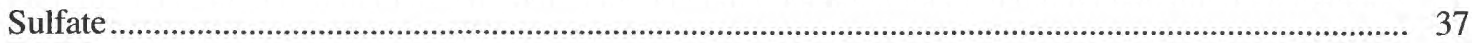

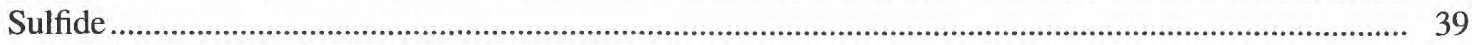

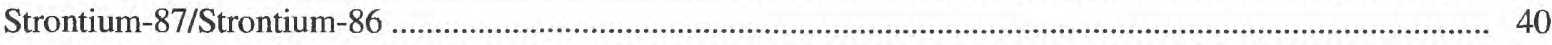

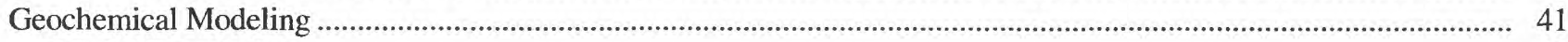

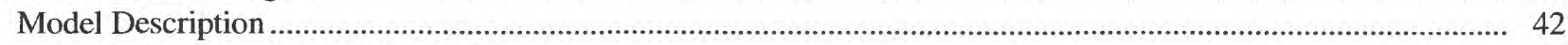

Shallow Upper Floridan Aquifer Models ................................................................................................... 43

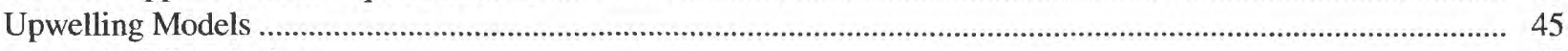

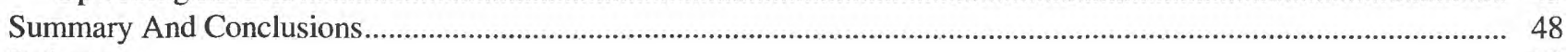

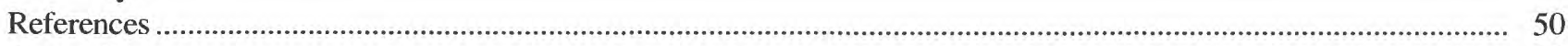

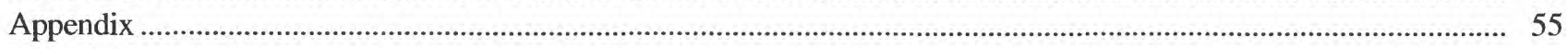


1. Map showing generalized distribution of sulfate and chloride concentrations in water from the Upper Floridan aquifer.

2. Graph showing profiles of sulfate and chloride concentrations in water from the intermediate aquifer system and Upper Floridan aquifer, collected as part of the Southwest Florida Water Management District's Regional Observation and Monitoring Program (ROMP)

3. Map showing ground-water flow directions based on predevelopment conditions and recharge and discharge areas in the Upper Floridan aquifer

4. Generalized hydrogeologic section showing flow patterns in the Upper Floridan aquifer between Polk County and coastal Sarasota County.....

5. Map showing rock sampling locations and sites with existing water-quality data from the middle confining unit, and water sampling locations and Upper Floridan aquifer flow paths

6. Graph showing the ratio of strontium-87 to strontium-86 in rock samples from the Hawthorn Group, Suwannee Limestone, and Avon Park Formation, compared to the ratio of strontium- 87 to strontium- 86 in seawater during the time of deposition

7. Cross sections along flow paths, showing open hole intervals of wells and lithologic and hydrogeologic units.

8. Graph showing profiles of vertical borehole flow under static conditions using the heat-pulse flow meter in wells 39,53 , and 55, which have large open hole intervals and are open exclusively to the Upper Floridan aquifer

Maps showing:

9. Sulfate concentrations in water from the shallowest sampling interval of the Upper Floridan aquifer, and the intermediate aquifer system, including areas where sulfate is significantly in excess of seawater mixing

10. Sulfide concentration in water from the shallowest sampling interval of the Upper Floridan aquifer, and the intermediate aquifer system.

11. Cross sections along flow paths, showing approximate areas where sulfate and chloride concentrations exceed 250 milligrams per liter in water from the Upper Floridan aquifer and intermediate aquifer system

12-13. Graphs showing:

12. Relation between chloride concentration and concentrations of sulfate, calcium, magnesium, strontium and sodium in water from the Upper Floridan aquifer and intermediate aquifer system

13. Relation between gypsum and celestite saturation index and sulfate concentration in water from the Upper Floridan aquifer and intermediate aquifer system.

14. Trilinear diagram illustrating chemical composition of water from the Upper Floridan aquifer

15-17. Graphs showing:

15. Changes in major ion concentrations in water from the shallowest sampling interval in the Upper

Floridan aquifer along the flow paths.

16. Changes in strontium concentration and strontium-to-sulfate molar ratio in water from the shallowest sampling interval in the Upper Floridan aquifer along the flow paths

17. Relation between enrichment or depletion of sulfate and calcium, sodium and calcium after gypsum dissolution, and magnesium and calcium after gypsum dissolution, in water from the Upper Floridan aquifer with chloride concentration greater than or equal to 250 milligrams per liter, and water from the Lower Floridan aquifer, Warm Mineral Springs, and the middle confining unit.

18. Trilinear diagram illustrating chemical composition of water from the intermediate aquifer system.......

19. Map showing major-ion water types from the intermediate aquifer system.

20-27. Graphs showing:

20. Relation between bicarbonate concentration and calcium-plus-magnesium concentration in water from the intermediate aquifer system, illustrating waters dominated by carbonate mineral dissolution compared to dedolomitization reactions and saltwater mixing.....

21. Relation between delta deuterium and delta oxygen-18 in water from the Upper Floridan aquifer and intermediate aquifer system

22. Relation between delta deuterium and chloride concentration in water from the Upper Floridan aquifer and intermediate aquifer system. 
23. Relation between delta carbon-13 and enrichment or depletion of magnesium relative to conservative saltwater mixing in water from the Upper Floridan aquifer.

24. Relation between delta sulfur- 34 of sulfate and sulfate concentration, and delta sulfur- 34 of sulfide and sulfate concentration in water from the Upper Floridan aquifer and intermediate aquifer system.

25. Relation between delta sulfur-34 of total sulfer and chloride concentration in water from the Upper Floridan aquifer and intermediate aquifer system with chloride concentration greater than 200 milligrams per liter

26. Relation between the ratio of strontium- 87 to strontium- 86 and strontium concentration in water from the Upper Floridan aquifer and intermediate aquifer system, plotted with the range of strontium- 87 to strontium-86 in seawater from the Miocene, Oligocene, and Eocene epochs.

27. Gypsum, dolomite, and calcite mass transfer computed with NETPATH between sections of flow paths, representing reactions in water from the shallowest sampling interval in the Upper Floridan aquifer.

28. Map showing amount of upwelling of sulfate-rich water computed with NETPATH along flow paths in the shallow part of the Upper Floridan aquifer, and inferred areas where upwelling significantly influences sulfate concentrations

\section{TABLES}

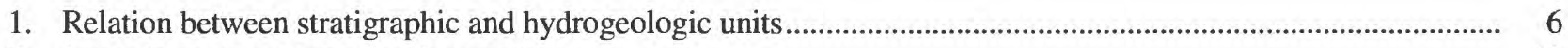

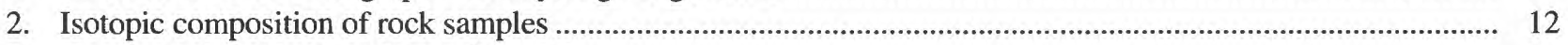

3. Concentration of selected constituents in gypsum......................................................................................... 14

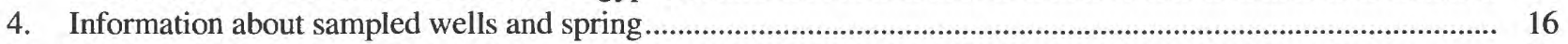

5. Water-quality data from the middle confining unit................................................................................ 30

6. NETPATH models between the shallowest Upper Floridan aquifer waters along the three flow paths................ 43

7. NETPATH models between the shallowest Upper Floridan aquifer waters along the three flow paths, including upwelling of deep, sulfate-rich ground water

\section{ALTITUDE DATUM}

Sea level: In this report, "sea level" refers to the National Geodetic Vertical Datum of 1929 (NGVD of 1929) -- a geodetic datum derived from a general adjustment of the first-order level nets of the United States and Canada, formerly called Sea Level Datum of 1929.

\section{ACRONYMS AND ABBREVIATIONS USED IN THIS REPORT:}

$\begin{array}{ll}\mathrm{mg} / \mathrm{L} & \text { milligrams per liter } \\ \mu \mathrm{g} / \mathrm{L} & \text { micrograms per liter } \\ \mathrm{mmol} / \mathrm{L} & \text { millimoles per liter } \\ \mathrm{P}_{\mathrm{CO}} & \text { partial pressure of carbon dioxide } \\ \mathrm{SI} & \text { saturation index } \\ \mathrm{d} & \text { day } \\ \mathrm{ft} & \text { feet } \\ \mathrm{ft}^{2} & \text { square feet } \\ \mathrm{ft}^{3} & \text { cubic feet } \\ \mathrm{mL} & \text { milliliter } \\ \mathrm{ppm} & \text { parts per million } \\ \mathrm{min} & \text { minutes } \\ \mathrm{DO} & \text { dissolved oxygen } \\ \mathrm{DOC} & \text { dissolved organic carbon } \\ \mu \mathrm{m} & \text { micrometer } \\ \delta & \text { delta } \\ { }^{34} \mathrm{~S} & \text { sulfur-34 } \\ { }^{13} \mathrm{C} & \text { carbon-13 } \\ \mathrm{D} & \text { deuterium } \\ { }^{18} \mathrm{O} & \text { oxygen-18 } \\ \text { SWFWMD } & \text { Southwest Florida Water Management District } \\ \text { USGS } & \text { United States Geological Survey } \\ \mathrm{L} & \text { liter }\end{array}$




\title{
Geochemical and Isotopic Composition of Ground Water, with Emphasis on Sources of Sulfate, in the Upper Floridan Aquifer and Intermediate Aquifer System in Southwest Florida
}

\author{
By Laura A. Sacks and Ann B. Tihansky
}

\section{Abstract}

In southwest Florida, sulfate concentrations in water from the Upper Floridan aquifer and overlying intermediate aquifer system are commonly above 250 milligrams per liter (the drinking water standard), particularly in coastal areas. Possible sources of sulfate include dissolution of gypsum from the deeper part of the Upper Floridan aquifer or the middle confining unit, saltwater in the aquifer, and saline waters from the middle confining unit and Lower Floridan aquifer. The sources of sulfate and geochemical processes controlling ground-water composition were evaluated for the Peace and Myakka River Basins and adjacent coastal areas of southwest Florida. Samples were collected from 63 wells and a saline spring, including wells finished at different depth intervals of the Upper Floridan aquifer and intermediate aquifer system at about 25 locations. Sampling focused along three ground-water flow paths (selected based on a predevelopment potentiometric-surface map). Ground water was analyzed for major ions, selected trace constituents, dissolved organic carbon, and stable isotopes (delta deuterium, oxygen-18, carbon- 13 of inorganic carbon, and sulfur-34 of sulfate and sulfide); the ratio of strontium-87 to strontium- 86 was analyzed for waters along one of the flow paths.
Chemical and isotopic data indicate that dedolomitization reactions (gypsum and dolomite dissolution and calcite precipitation) control the chemical composition of water in the Upper Floridan aquifer in inland areas. This is confirmed by mass-balance modeling between wells in the shallowest interval in the aquifer along the flow paths. However, gypsum occurs deeper in the aquifer than these wells. Upwelling of sulfate-rich water that previously dissolved gypsum in deeper parts of the aquifer is a more likely source of sulfate than gypsum dissolution in shallow parts of the aquifer. This deep ground water moves to shallower zones in the aquifer discharge area.

Saltwater from the Upper Floridan aquifer has not dissolved significant amounts of gypsum compared to fresher water in the aquifer. This is consistent with a shallow seawater source for the saltwater, rather than a deeper source from the underlying middle confining unit or Lower Floridan aquifer, which would have elevated sulfate concentrations. Ion exchange and dolomitization may be important reactions for saltwater in the aquifer. According to geochemical modeling, the freshwater end member for water in the saltwater mixing zone in the southwestern part of the study area is not upgradient water from the Upper Floridan aquifer that dissolved gypsum. Instead, this water 
appears to be isolated from the regional freshwater flow system and may be part of a more localized flow system.

The chemical and isotopic composition of water in the intermediate aquifer system is controlled by differences in extent of reactions with aquifer minerals, upward leakage from the Upper Floridan aquifer, and saltwater mixing. In inland areas, water generally is characterized by relatively low sulfate concentrations (less than 250 milligrams per liter) and differences in extent of carbonate mineral dissolution. Some inland waters have elevated chloride concentrations, which may be related to evaporation prior to recharge. In coastal Sarasota County and in isolated inland areas, water from the intermediate aquifer system has high sulfate concentrations characteristic of dedolomitization waters from the Upper Floridan aquifer. The chemical and isotopic composition of these waters is controlled by upward leakage from the Upper Floridan aquifer, which naturally occurs in the discharge area but may be locally enhanced by pumping or interconnection of wells open to both aquifer systems. In western Charlotte County, the waters are dominated by sodium and chloride, and their compositions are consistent with mixing between saltwater and inland intermediate aquifer system water that has not been influenced by discharge from the Upper Floridan aquifer.

Deeply circulating ground-water flow paths apparently control the high sulfate concentrations in the shallow part of the Upper Floridan aquifer in western Sarasota County. In the recharge area, water moves downward to deep parts of the aquifer and dissolves gypsum. This dissolution occurs within the freshwater flow system, rather than the source being from diffusion or upward leakage of water from the middle confining unit or the Lower Floridan aquifer. Downgradient, this sulfate-rich water moves upward to shallower parts of the aquifer and into the overlying intermediate aquifer system, landward of the saltwater mixing zone. In the vicinity of the Peace River, higher sulfate concentrations are the result of upwelling because of discharging conditions in the aquifer. This discharge probably causes less freshwater to move toward the coast, and flow paths there may not circulate as deep as in western Sarasota County, where sulfate concentrations are much higher.

\section{INTRODUCTION}

The Upper Floridan aquifer is a major source of drinking water for Florida. Water in the aquifer is generally nonpotable in coastal areas because sulfate concentrations exceed $250 \mathrm{mg} / \mathrm{L}$ (the drinking water standard; Florida Department of State, 1993). Sulfate concentrations are typically low in inland areas, particularly where the aquifer is unconfined; high sulfate concentrations, however, do occur in isolated inland locations of northwest central Florida (Sacks, 1996). In coastal southwest Florida, where the aquifer is confined, sulfate concentrations are particularly high and in places exceed $1,000 \mathrm{mg} / \mathrm{L}$. High sulfate concentrations do not necessarily correspond to areas of saltwater mixing, where chloride concentrations increase (fig. 1). Water from the Upper Floridan aquifer is chemically stratified in inland southwest Florida, with sulfate concentrations generally increasing with depth (Sprinkle, 1989; Southwest Florida Water Management District, 1991; Sacks and others, 1995).

The overlying intermediate aquifer system is also an important source of drinking water in southwest Florida. Sulfate concentrations in the intermediate aquifer system are typically less than $250 \mathrm{mg} / \mathrm{L}$, except in coastal areas and in the lower Peace River Basin (Wolansky, 1983; Duerr and Enos, 1991; Southwest Florida Water Management District, 1991). A better understanding of vertical and areal sulfate sources in both aquifers is essential, particularly because heavy pumping could induce movement of high sulfate water to zones in the aquifers containing lower sulfate concentrations.

Several sources of sulfate exist in the aquifer systems. The most apparent source is dissolution of evaporite minerals (gypsum and anhydrite), which are present at the base of the Upper Floridan aquifer or in the underlying middle confining unit and Lower Floridan aquifer. This source requires an upward movement of water because the occurrence of evaporites are considerably deeper than zones in which most wells are finished. Trace evaporites have not been detected in well cuttings or cores in shallow parts of the aquifer or in the intermediate aquifer system. 


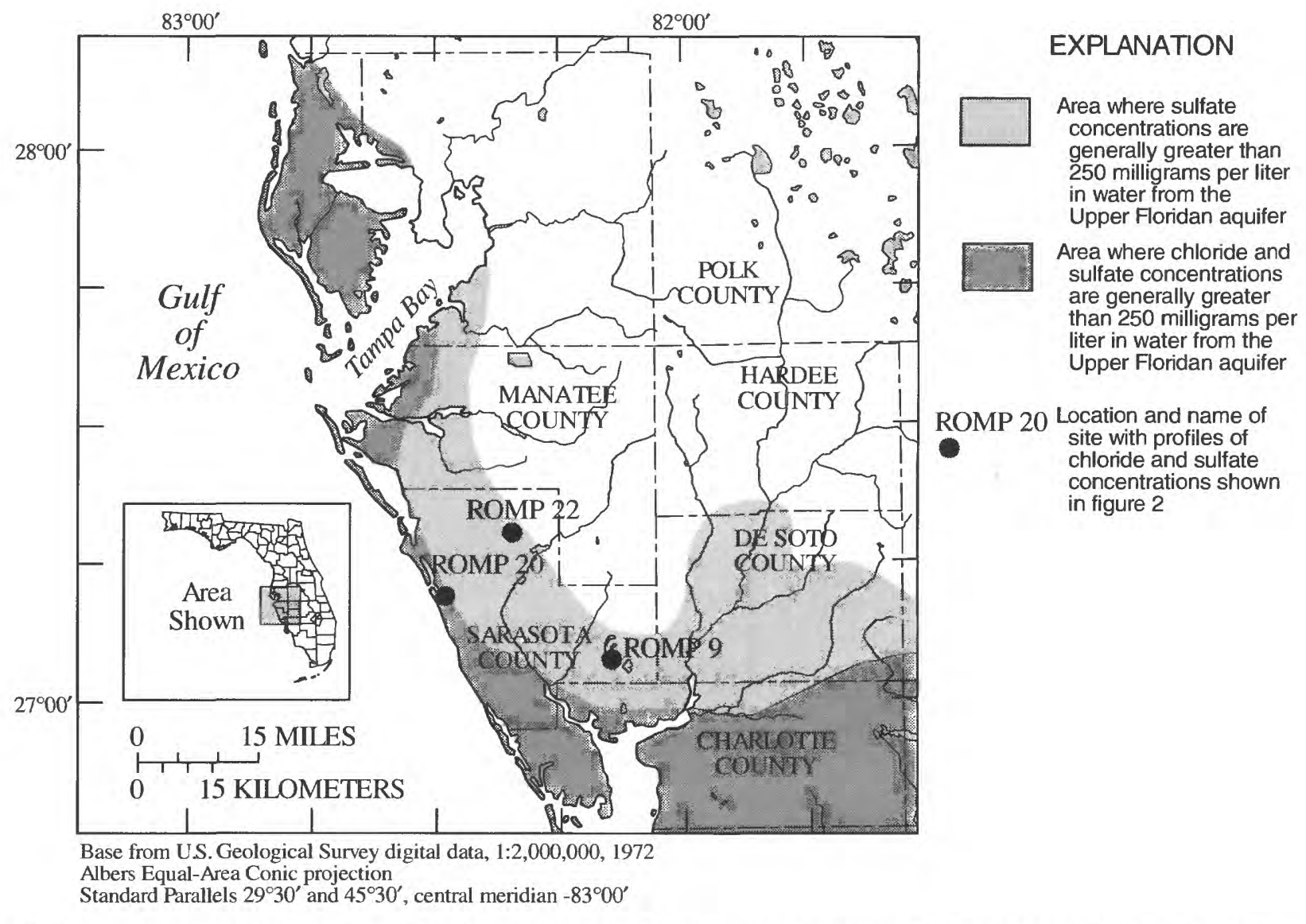

Figure 1. Generalized distribution of sulfate and chloride concentrations in water from the Upper Floridan aquifer. (Modified from Sprinkle, 1989; Southwest Florida Water Management District, 1991; and Katz, 1992.)

Saltwater mixing is another source of sulfate in coastal areas. Other possible sources include diffusion of sulfate from pore waters in the middle confining unit, oxidation of sulfide minerals, such as pyrite, oxidation of organic sulfur from peat beds, and diffusion of sulfate from clays in overlying beds. Surficial sources of sulfate include meteoric rainwater that contains sulfate, oxidation of organic sulfur, and anthropogenic sources such as fertilizers applied in the form of sulfate salts.

Sulfur isotope data collected in a regional study of the Upper Floridan aquifer were used successfully to delineate sulfate sources on a regional scale (Rightmire and others, 1974; Rye and others, 1981). For the most part, low sulfate concentrations (less than 100 $\mathrm{mg} / \mathrm{L}$ ) and isotopically light sulfate (less than 18 per mil) were detected in the aquifer recharge area and were attributed to atmospheric precipitation. Downgradient and in confined parts of the aquifer, isotopically heavier sulfate (greater than 22 per mil) was attributed to gypsum dissolution and marine sulfate. These regional studies, however, did not examine vertical variability of sulfate concentrations and sources in the chemically stratified water of the Upper Floridan aquifer.

Vertical variability in the composition of ground water may be an indicator of upward flow (or upwelling) from deeper parts of the aquifer. Upwelling may be caused by temperature and density gradients in deep, saline parts of the Floridan aquifer system (Kohout, 1967; Kohout and others, 1977).

Upwelling also is associated with upward discharge at the end of deeply circulating, regional flow paths (Jones and others, 1993; Sacks and others, 1995). Upward flow within the aquifer may be accelerated by preferential flow through subsurface fractures (Kaufman and Dion, 1967; Jones and Upchurch, 1993).

The degree of stratification of sulfate in waters from the Upper Floridan aquifer and intermediate aquifer system varies in southwest Florida. Waterquality data collected during coring and drilling of several sites by Southwest Florida Water Management District (written commun., 1995) demonstrate how variable the increase in sulfate with depth is in this region (fig. 2). In some locations, sulfate concentrations increased with depth (for example, 


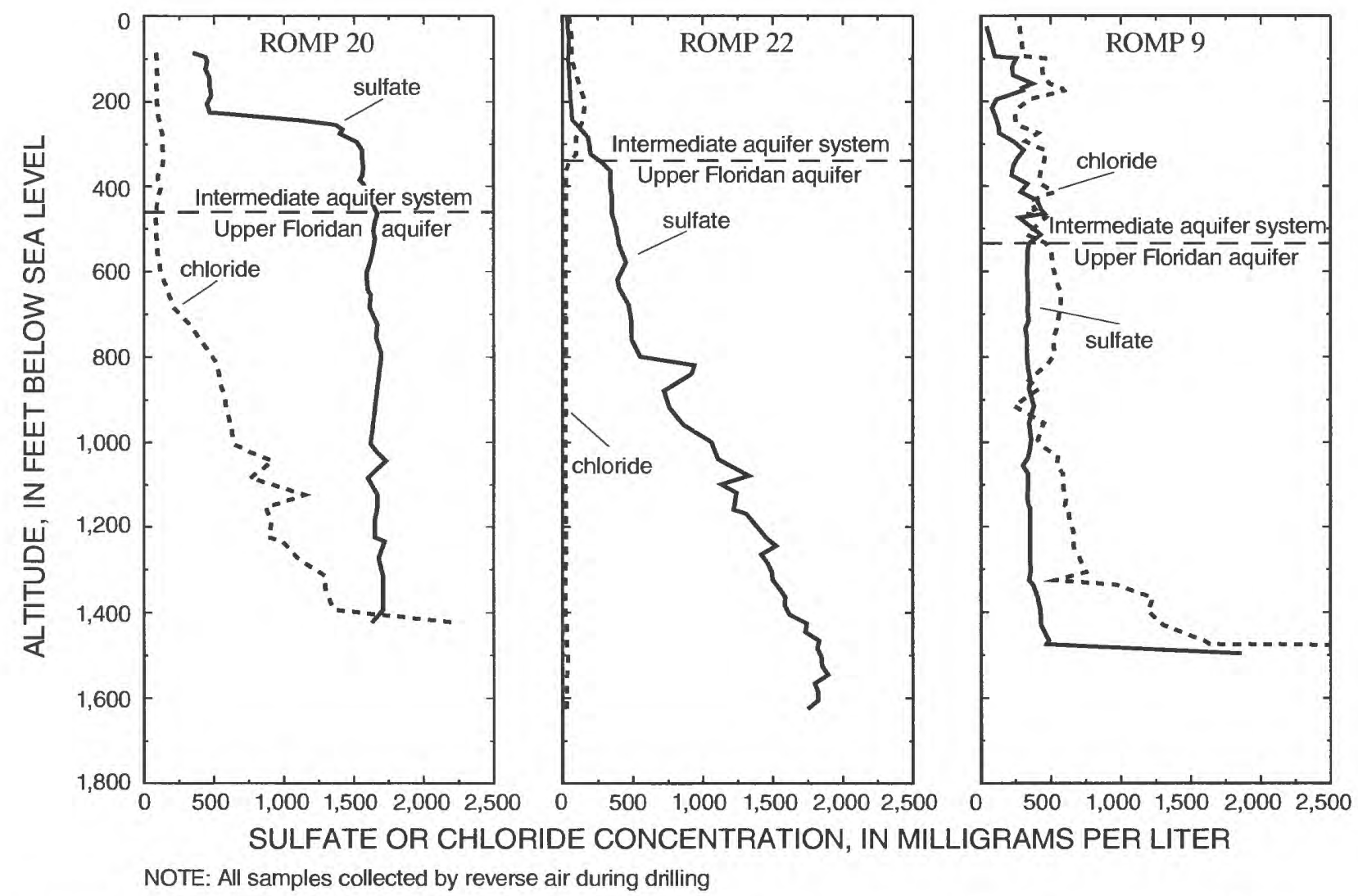

Figure 2. Profiles of sulfate and chloride concentrations in water from the intermediate aquifer system and Upper Floridan aquifer, collected as part of the Southwest Florida Water Management District's Regional Observation and Monitoring Program (ROMP). (Locations of drill sites shown in figure 1.)

ROMP 22), but in other locations, sulfate concentrations remained relatively low in the deeper part of the Upper Floridan aquifer (for example, ROMP 9; fig. 2). This variability may be related to differences in the occurrence of gypsum or anhydrite in the aquifer. It also may indicate differences in the amount of upwelling of sulfate-rich water from deeper parts of the aquifer. At ROMP 20 in coastal Sarasota County, sulfate concentrations were high (about $1,500 \mathrm{mg} / \mathrm{L}$ ) and remained relatively constant with depth (fig. 2). At this site, chloride concentrations increase with depth. The differences in the stratification of sulfate in the aquifers indicate that sources may vary both vertically and laterally.

Population growth and agriculture have been placing increased demands on ground-water resources in southwest Florida. Heavy pumping of the Upper Floridan aquifer has resulted in significant depressions in the potentiometric surface compared to predevelopment conditions (Yobbi, 1983; Ryder, 1985; Bush and Johnston, 1988). This heavy pumping can render water supplies nonpotable because of lateral saltwater intrusion along coastal areas and upwelling of more mineralized water from deeper parts of the aquifer. Degradation of freshwater resources also can occur by movement of mineralized water from the Upper Floridan aquifer to the intermediate aquifer system through wells open to both aquifers (Hutchinson, 1992; Metz, 1996). A better understanding of the vertical and lateral variability in water quality and solute sources can help water managers more judiciously develop water resources.

In 1991, the U.S. Geological Survey (USGS) began a cooperative study with the Southwest Florida Water Management District (SWFWMD) to evaluate sulfate sources in the Upper Floridan aquifer and, locally, in the intermediate aquifer system in two separate areas of the water management district. One area is south of Tampa Bay in the confined part of the aquifer. The other study area is in the northern part of the District, where isolated high sulfate concentrations have been observed (Sacks, 1996). This report focuses on the southern study area. 


\section{Purpose and Scope}

The purpose of this report is to evaluate sources of sulfate in the Upper Floridan aquifer and intermediate aquifer system in southwest Florida, specifically in the Peace and Myakka River Basins and adjacent coastal areas. In addition, processes controlling the geochemical and isotopic composition of the ground water are described, and hypotheses about reactions occurring in the Upper Floridan aquifer are examined using geochemical mass-balance modeling. Water samples were collected at 63 wells from various depth intervals in the Upper Floridan aquifer and intermediate aquifer system at about 25 separate locations in parts of Sarasota, Charlotte, De Soto, Hardee, Manatee, and Polk Counties. Samples also were collected from a saline spring (Warm Mineral Springs) and from the Lower Floridan aquifer. Existing chemical data were compiled from the middle confining unit.

The sampling focused along three flow paths in the Upper Floridan aquifer, from the recharge area, where sulfate concentrations are low, to the coastal discharge area, where sulfate concentrations are greater than the drinking water standard. Flow paths were derived from a map estimating the potentiometric surface for predevelopment conditions (Bush and Johnston, 1988). Samples were collected at other locations for better areal coverage and to better define saline waters. Water was sampled for major ions, selected trace elements, dissolved organic carbon, field parameters (temperature, $\mathrm{pH}$, specific conductance, alkalinity, sulfide), and stable isotopes (sulfur34 , deuterium, oxygen-18, and carbon-13). The ratio of strontium-87 to strontium-86 was analyzed for waters along one of the flow paths. Limited chemical and isotopic analysis of minerals present in the aquifer was necessary for geochemical modeling and to identify sources of sulfate and carbon in the aquifer systems.

\section{Acknowledgments}

Well selection and sampling efforts depended upon the generous assistance of many individuals at the Southwest Florida Water Management District, including personnel from the Ambient Ground-Water Quality Monitoring Program (with particular thanks to Eric DeHaven and Gregg Jones), Regional Observation and Monitoring Program (ROMP) (with particular thanks to David DeWitt), and Resource Data
Department. The authors also would like to extend thanks to well owners and local water utility departments for allowing us to sample and for providing us with specific information about the wells. Rock core and cuttings analyzed for this study were provided by the Florida Geological Survey, Law Environmental, Inc., David Budd (University of Colorado), and the Southwest Florida Water Management District. Shelley Kauffman, University of Virginia, volunteered her time to assist in field efforts.

\section{GEOLOGIC AND HYDROGEOLOGIC FRAMEWORK}

The study area is underlain by thick sequences of carbonate rocks that comprise the Florida carbonate platform. The limestones, dolomites and minor evaporites (gypsum and anhydrite) which make up the Florida carbonate platform range in age from Cretaceous to late Oligocene or early Miocene. These rocks overlie deeper volcanic, metamorphic, and Mesozoic sedimentary rocks (Applin and Applin, 1965; Smith, 1982). The Floridan aquifer system is within the vertically continuous carbonate rocks of Tertiary age. These carbonate rocks are overlain by interbedded clastic and carbonate rocks, which are primarily Miocene in age and make up the intermediate aquifer system. The geology and hydrogeology of the Floridan aquifer system are summarized in detail in numerous reports (for example, Chen, 1965; Ryder, 1985; Miller, 1986; Bush and Johnston, 1988). The geology of the Hawthorn Group, which comprises most of the intermediate aquifer system, is described in detail by Scott (1988). Localized studies of the hydrogeology of the intermediate aquifer system include Wolansky (1983), Duerr and Wolansky (1986), Duerr and Enos (1991) and Barr (1996). Aquifer and confining unit classifications used in this report correspond to those of the Southeast Geological Society (1986). Stratigraphic classifications are based on Miller (1986) and Scott (1988).

\section{Hydrogeology}

A multilayered ground-water flow system exists in southwest Florida (table 1). The shallowest aquifer is the unconfined surficial aquifer system, generally occurring within Pleistocene to Holocene deposits. 
Table 1. Relation between stratigraphic and hydrogeologic units.

\begin{tabular}{|c|c|c|c|c|}
\hline System & Series & $\begin{array}{c}\text { Stratigraphic } \\
\text { unit }\end{array}$ & \multicolumn{2}{|c|}{$\begin{array}{l}\text { Hydrogeologic } \\
\text { unit }\end{array}$} \\
\hline Quaternary & $\begin{array}{c}\text { Holocene } \\
\text { Pleistocene }\end{array}$ & $\begin{array}{l}\text { Terrace and } \\
\text { undifferen- } \\
\text { tiated } \\
\text { deposits }\end{array}$ & & $\begin{array}{l}\text { Surficial } \\
\text { aquifer } \\
\text { system }\end{array}$ \\
\hline \multirow[t]{10}{*}{ Tertiary } & Pliocene & $\begin{array}{l}\text { Tamiami } \\
\text { Formation }\end{array}$ & \multirow{4}{*}{\multicolumn{2}{|c|}{ Intermediate }} \\
\hline & Miocene & $\begin{array}{l}\text { Hawthorn } \\
\text { Group }{ }^{1}\end{array}$ & & \\
\hline & & $\begin{array}{l}\text { Arcadia } \\
\text { Formation }\end{array}$ & & \\
\hline & \multirow[b]{2}{*}{ Oligocene } & $\begin{array}{c}\text { Tampa } \\
\text { Member }\end{array}$ & & \\
\hline & & $\begin{array}{l}\text { Suwannee } \\
\text { Limestone }\end{array}$ & \multirow{6}{*}{ 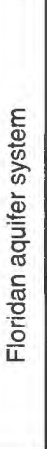 } & Upper \\
\hline & \multirow{4}{*}{ Eocene } & $\begin{array}{c}\text { Ocala } \\
\text { Limestone }\end{array}$ & & Floridan \\
\hline & & \multirow[t]{2}{*}{$\begin{array}{l}\text { Avon Park } \\
\text { Formation }\end{array}$} & & aquifer \\
\hline & & & & Middle con- \\
\hline & & $\begin{array}{l}\text { Oldsmar } \\
\text { Formation }\end{array}$ & & \multirow{2}{*}{$\begin{array}{l}\text { Lower } \\
\text { Floridan } \\
\text { aquifer }\end{array}$} \\
\hline & Paleocene & $\begin{array}{c}\text { Cedar Keys } \\
\text { Formation }\end{array}$ & & \\
\hline
\end{tabular}

${ }^{1}$ Based on nomenclature of Scott (1988)

The surficial aquifer system typically ranges from 25 to $100 \mathrm{ft}$ in thickness and consists of varying proportions of sand, shell, clay, reworked phosphate grains, and very localized carbonate beds. The surficial aquifer system is not usually a large producer of water; however, in coastal areas, well fields commonly have wells that tap the surficial aquifer system. Numerous privately owned wells also tap this aquifer system. Clays in the lower part of the deposits separate the surficial aquifer system from the intermediate aquifer system.

\section{Intermediate Aquifer System}

The intermediate aquifer system has multiple permeable zones that correspond to carbonate units and coarser clastic deposits of the Hawthorn Group and locally the Tamiami Formation (Wolansky, 1983; Duerr and Enos, 1991; Barr, 1996). Interbedded clays and finer grained clastics separate these permeable zones. The degree of connection between permeable zones and the areal extent of permeable zones is not well understood because of the heterogeneous nature of the Hawthorn Group.
Rocks of the Hawthorn Group range in age from late Oligocene to early Pliocene (Wingard and others, 1993; Covington, 1993; Missimer and others, 1994; Scott and others, 1994), with most deposits being Miocene in age. The Hawthorn Group is a heterogeneous unit that generally consists of interbedded siliciclastic (sands, silts, and clays) and carbonate rocks. The diversity in lithology is the result of the variety of depositional environments during the Miocene, including open to shallow marine, estuarine, and fluvial environments (Gilboy, 1985). In the study area, the Hawthorn Group is subdivided into the Peace River and Arcadia Formations (Scott, 1988). The Peace River Formation, which forms the upper unit, consists primarily of interbedded quartz sand and clay, with occasional carbonate and phosphatic beds (Scott, 1988). The Peace River Formation is typically 50 to $100 \mathrm{ft}$ thick in the study area. The underlying Arcadia Formation consists of limestone and dolomite with varying amounts of quartz sand, clay and phosphate grains. The Arcadia Formation ranges in thickness from less than $100 \mathrm{ft}$ in the northern part of the study area to greater than $400 \mathrm{ft}$ in the southwest part of the study area (Scott, 1988).

Rocks in the lower Arcadia Formation usually have distinctly lower permeability than underlying carbonate rocks of the Upper Floridan aquifer, and generally form the base of the intermediate aquifer system in the study area (Miller, 1986). The confining properties, however, probably vary considerably within the study area. Transmissivity values in the intermediate aquifer system are highly variable and range from 400 to 9,000 $\mathrm{ft}^{2} / \mathrm{d}$ (Ryder, 1982; Wolansky, 1983).

The intermediate aquifer system is an important water source in the study area because water quality is typically better than in the underlying Upper Floridan aquifer. Thus, many private and public supply wells are completed in this aquifer. Irrigation wells and public supply wells are commonly open to both the intermediate aquifer system and the Upper Floridan aquifer to optimize well yield. This practice, however, is not encouraged because more mineralized water from the Upper Floridan aquifer can move upward in the borehole, degrading water quality in the intermediate aquifer system (Hutchinson, 1992; Duerr and Enos, 1991; Metz, 1996). Near the coast, the intermediate aquifer system is developed as a public water supply for coastal communities; water from lower permeable zones often is mineralized and is treated by reverse-osmosis (Wolansky, 1983). 
Flow in the intermediate aquifer system is usually west or southwest toward the coast, except in the northern Hardee and southern Polk Counties, where flow is toward the Peace River (Wolansky, 1983; Duerr and Enos, 1991; Mularoni, 1992a). In much of the study area, water is recharged to the intermediate aquifer system from the surficial aquifer system. However, the intermediate aquifer system locally discharges in the vicinity of the Peace and Myakka Rivers and in coastal areas, where heads in the intermediate aquifer system are higher than in the overlying surficial aquifer system (Wolansky, 1983). Throughout much of Sarasota County and most of De Soto and Hardee Counties, water also enters the intermediate aquifer system through upward leakage from the Upper Floridan aquifer.

\section{Floridan Aquifer System}

The Floridan aquifer system is a vertically continuous sequence of carbonate rocks of generally high permeability that are hydraulically connected in varying degrees (Miller, 1986). In the study area, the aquifer system is separated by the less-permeable middle confining unit into an Upper and Lower Floridan aquifer.

\section{Upper Floridan Aquifer}

The Upper Floridan aquifer typically consists of limestone and dolomite of the Suwannee Limestone, the Ocala Limestone, and the Avon Park Formation (table 1). (Where permeability at the bottom of the Hawthorn Group is high, usually in the carbonate-rich Tampa Member of the Arcadia Formation, this unit also is considered part of the aquifer.) The Suwannee Limestone, of early Oligocene age, consists primarily of fine to medium-grained pelletal limestone, with trace amounts of sand and clay in the upper portions. The Suwannee Limestone is not present in northern and eastern Polk County, where the limestone presumably has been eroded; its maximum thickness is about $400 \mathrm{ft}$ in Sarasota County (Miller, 1986). The underlying Ocala Limestone, of late Eocene age, is typically 200 to $400 \mathrm{ft}$ thick in the study area and generally is composed of soft, fossiliferous to micritic limestone (Miller, 1986). Lower parts of the Ocala may be locally dolomitized. Both the Suwannee and Ocala Limestones were deposited in open to marginal marine environments, and evaporite minerals are not present (Miller, 1986; Randazzo and others, 1990). The underlying Avon Park Formation of middle Eocene age is typically 1,200 to $1,500 \mathrm{ft}$ thick in the study area. The upper part of the Avon Park is usually dolomitized, although sometimes it consists of limestone; evaporites are not typically present in the upper part of this formation. The lower part of the Avon Park Formation (formerly the Lake City Limestone; Miller, 1986) consists primarily of dolomite, with intergranular gypsum and beds of anhydrite and peat occurring in some locations. The uppermost gypsiferous bed typically forms the base of the Upper Floridan aquifer.

Significant permeable zones occur in the upper part of the Suwannee Limestone and from the lower part of the Ocala Limestone to the upper part of the Avon Park Formation. In the upper limestone sections, porosity is generally intergranular, whereas in the more crystalline dolomite rocks of the Avon Park Formation, porosity is dominated by fractures. Transmissivity values are typically 100,000 to $200,000 \mathrm{ft}^{2} / \mathrm{d}$ (Ryder, 1985).

In inland parts of the study area, water from the highly productive Upper Floridan aquifer has been heavily developed for agriculture and public water supply, and wells commonly are drilled into the upper part of the Avon Park Formation. Closer to the coast, chloride and sulfate concentrations are generally higher than regulations permit for potable water supplies; consequently, water from the Upper Floridan aquifer typically is treated by reverse osmosis and mixed with water from the intermediate aquifer system to supplement public water supplies. Near the coast, the lower part of the Upper Floridan aquifer (which corresponds to the Avon Park highly permeable zone and contains saline water) is sometimes used for injection of effluent from sewage treatment plants and reverse osmosis desalinization plants (Hutchinson, 1992).

\section{Middle Confining Unit}

The base of the Upper Floridan aquifer and the top of the middle confining unit occurs in a zone of low permeability gypsiferous dolomite and dolomitic limestone. This zone usually corresponds to the middle to lower part of the Avon Park Formation (Miller, 1986; Hickey, 1990). The Avon Park Formation was deposited in a peritidal warm-water carbonate bank, and evaporite deposition occurred in an extensive sabkha or tidal flat environment analogous to the modern Persian Gulf (Miller, 1986; Randazzo and others 1990; Cander, 1991). Gypsum and anhydrite deposits are not continuous and probably were formed in isolated evaporative basins on a carbonate bank separated from the shallow sea. Gypsum typically occurs as nodules within the carbonate rock, but the gypsum is sometimes massive and layered (Hickey, 1990; Cander, 1991). Some of the nodules have a central core of anhydrite. Secondary gypsum also infills preexisting pore spaces in the rock, resulting in reduced permeability of the rock. 


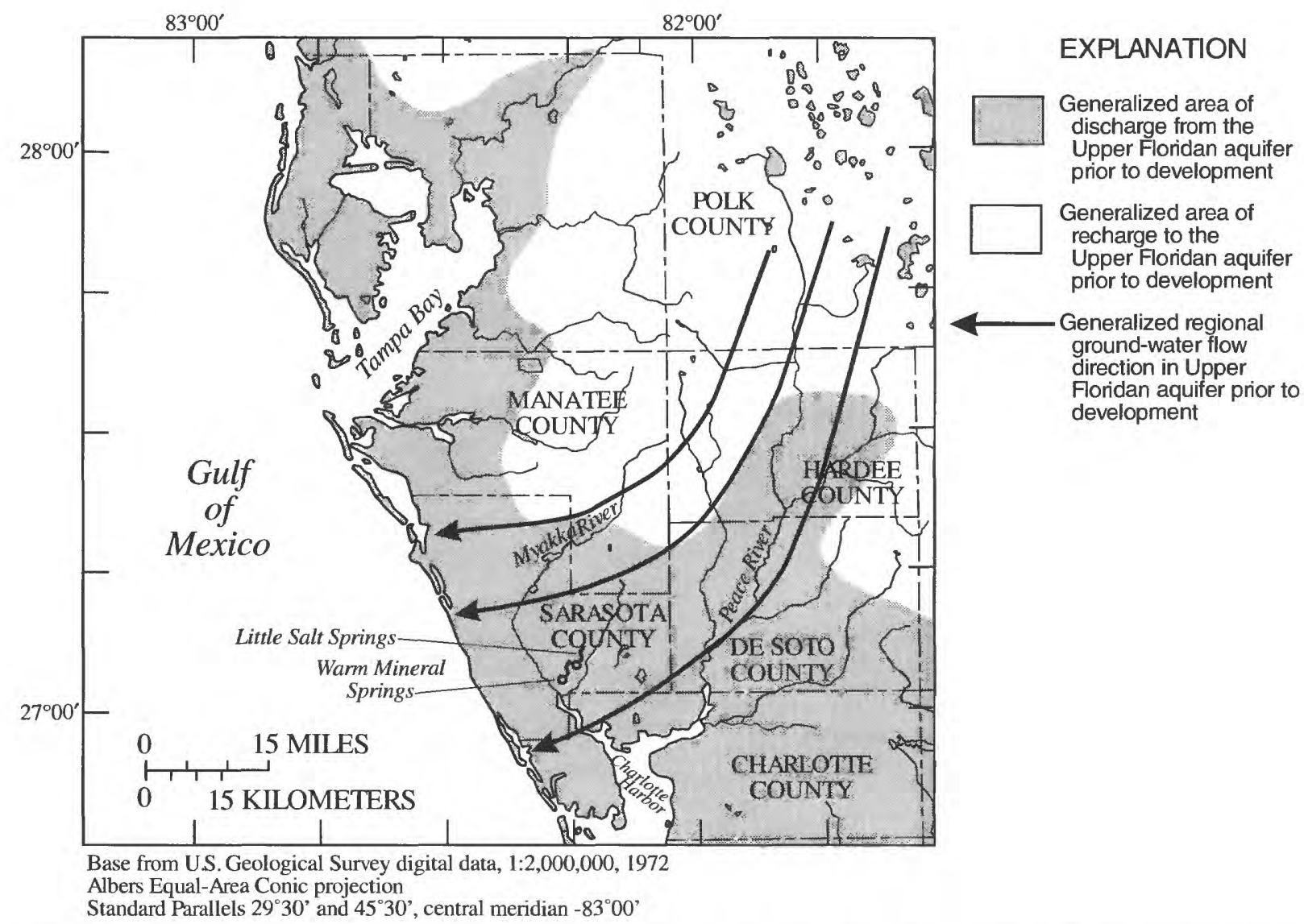

Figure 3. Ground-water flow directions based on predevelopment conditions and recharge and discharge areas in the Upper Floridan aquifer. (Modified from Bush and Johnston, 1988; Ryder, 1985.)

In the study area, the middle confining unit generally is present between about $1,200 \mathrm{ft}$ below sea level in the northern part of the study area and about $1,900 \mathrm{ft}$ below sea level in western Sarasota County (Miller, 1986). The occurrence and thickness of the middle confining unit varies because of the localized nature of evaporite beds. The hydraulic conductivity of the middle confining unit $(0.01$ to $0.1 \mathrm{ft} / \mathrm{d}$; Hickey, 1990 ) is many orders of magnitude lower than the conductivity of the overlying Upper Floridan aquifer. However, the degree of confinement is not well understood. Miller (1986) describes the middle confining unit as a "nonleaky confining bed," whereas Hickey (1990) concludes that the confining properties of this unit may be more analogous to a fine-grained sandstone than to a compact clay bed.

\section{Lower Floridan Aquifer}

The underlying Lower Floridan aquifer consists of carbonate rocks of the Oldsmar and Cedar Keys Formations. The Oldsmar Formation, of early Eocene age, consists of about $1,000 \mathrm{ft}$ of limestone, dolomite, and thin beds of evaporites and chert. Rocks of the underlying Cedar Keys Formation of Paleocene age consist of dolomite with variable amounts of gypsum and anhydrite. The base of the Floridan aquifer system occurs in areally extensive, thick anhydrite beds in the lower twothirds of this formation (Miller, 1986). Water in the Lower Floridan aquifer is saline and is not utilized in the study area. The Lower Floridan aquifer is used for waste-water injection in some places.

\section{Ground-Water Flow and Circulation}

Prior to ground-water development, water in the Upper Floridan aquifer flowed west-southwest toward the coast from a high in the potentiometric surface in Polk County (fig. 3) (Bush and Johnston, 1988). During the past half century, regional declines in the potentiometric surface have occurred in southwest Florida because of large ground-water withdrawals and slow recharge rates due to the presence of thick confining beds (Ryder, 1985). As a result, the modern potentiometric surface is considerably different from predevelopment conditions (Yobbi, 1983; Ryder, 
1985; Mularoni, 1992b). Ground-water flow rates are very sluggish in the confined part of the aquifer (Bush and Johnston, $1988 ; 20$ to $30 \mathrm{ft} /$ year according to ${ }^{14} \mathrm{C}$ dating by Plummer and others, 1983). Because flow is so slow, insufficient time has passed for ground-water development to affect regional ground-water chemistry in the Upper Floridan aquifer. However, induced upwelling can occur in isolated areas of high pumpage, which can locally impact water quality in shallow parts of the aquifer (Steinkampf, 1982). For this study, predevelopment flow paths are assumed to be valid for evaluating the chemical character of water within the Upper Floridan aquifer.

Although lateral flow paths are assumed from potentiometric-surface maps, the depth of ground-water circulation within the Upper Floridan aquifer is not well understood. Downward head gradients are present in the Upper Floridan aquifer in recharge areas and upward head gradients are present in aquifer discharge areas. Areas of recharge from the intermediate aquifer system to the Upper Floridan aquifer include eastern Manatee County, northern Hardee County, and Polk County (except in the immediate vicinity of the Peace River; fig. 3) (Ryder, 1985; Aucott, 1988). Highest recharge rates are in ridge areas of Polk County.

Areas of discharge from the Upper Floridan aquifer are near the coast and in the lower Peace River and Myakka River Basins (fig. 3). In river valleys, upward discharge is caused by decreased heads in the shallower aquifers. Upward flow within and between aquifers may be enhanced by preferential flow through deep fractures or faults. In the Peace River valley upwelling probably moves water with higher solute concentrations from deeper to shallower parts of the Upper Floridan aquifer (Kaufman and Dion, 1968; Jones and Upchurch, 1993). In coastal areas, the saltwater interface drives upwelling within the Upper Floridan aquifer and upward discharge into the intermediate aquifer system (fig. 4). Saline water occurs at depth in the Upper Floridan aquifer near the coast and below the base of the aquifer in inland areas. Prior to ground-water development, the freshwater flow system continued offshore and discharged into the Gulf of Mexico. Results from a solute-transport model of predevelopment conditions, along a cross section near the City of Sarasota, indicate that more than half of the freshwater in the aquifer previously discharged beneath the Gulf of Mexico (HydroGeoLogic, Inc., 1994).

Large declines in the potentiometric surface of the Upper Floridan aquifer have resulted in reversals in head gradients between the Upper Floridan aquifer and the intermediate aquifer system in some parts of the study area (Ryder, 1985). Consequently, some dis-

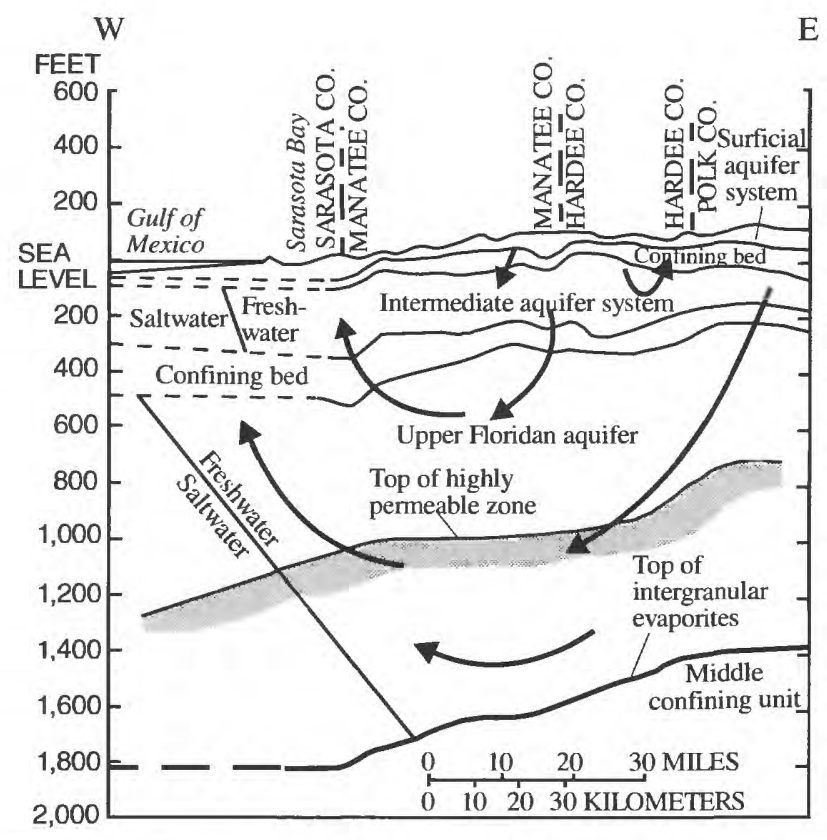

Figure 4. Generalized hydrogeologic section showing flow patterns in the Upper Floridan aquifer between Polk County and coastal Sarasota County. (Modified from Ryder, 1985.)

charge areas prior to ground-water development currently have the potential to receive recharge from the intermediate aquifer system. Changes from discharge to recharge conditions have occurred in parts of northeastern Sarasota County and in the Peace River Basin in northern De Soto and central Hardee Counties.

Because of the high degree of confinement of the aquifer systems, very few springs are present in the study area (fig. 3). The largest springs are Warm Mineral Springs and Little Salt Springs within the lower Myakka River Basin. Warm Mineral Springs discharges warm, saline water similar to water in deeper parts of the Upper Floridan aquifer (Hutchinson; 1992). Kohout and others (1977) suggested that water discharging from this spring has circulated deeply within the Floridan platform. Little Salt Springs is less saline (about 7 percent modern seawater according to the chloride concentration) than Warm Mineral Springs (about 50 percent modern seawater), but still probably derives some component from the Upper Floridan aquifer. Several small springs also occur in the vicinity of the Peace River; the springs probably discharge from the intermediate aquifer system (Hammett, 1990).

\section{Mineralogical Data from Aquifers}

Mineralogy and the chemical and isotopic composition of major minerals in the aquifer systems were evaluated to assist in interpreting the chemical and isotopic composition of the ground water. The mineralogy of the 
Floridan aquifer system has been defined in previous studies, with a thorough summary by Sprinkle (1989). Calcite and dolomite are, by far, the dominant minerals in the aquifer system. Most of the calcite ranges from pure $\mathrm{CaCO}_{3}$ to low magnesian calcite (less than 2 mole percent magnesium; Hanshaw and others, 1971). Dolomites range in composition from stoichiometric dolomite $\left(\mathrm{CaMg}\left(\mathrm{CO}_{3}\right)_{2}\right.$ ) to $\mathrm{Ca}_{1.12} \mathrm{Mg}_{0.88}\left(\mathrm{CO}_{3}\right)_{2}$ (Hanshaw and others, 1971; Randazzo and Hickey, 1978). It is generally thought that dolomites of the Avon Park Formation were formed not long after deposition during the middle Eocene by a platform-wide influx of normal to hypersaline seawater (Cander, 1991). Multiple dolomitization episodes, however, probably occurred. Some dolomites probably formed in saltwater mixing zones at later times (Hanshaw and Back, 1972; Randazzo and Hickey, 1978; Cander, 1991). This variability in origin probably affects the composition of dolomites and influences the solubility of dolomite in ground water (Sprinkle, 1989).

Gypsum $\left(\mathrm{CaSO}_{4} \cdot 2 \mathrm{H}_{2} \mathrm{O}\right)$ and anhydrite $\left(\mathrm{CaSO}_{4}\right)$ occur in deeper parts of the aquifer system (the Avon Park Formation and deeper units). Halite and other hypersaline evaporite minerals are not present in these deposits. Evaporite minerals have not been noted in formations overlying the Avon Park Formation, which corresponds to shallow parts of the Upper Floridan aquifer.

Other minor minerals include quartz and chert, apatite, clay minerals (kaolinite, glauconite, and possibly montmorillonite), potassium feldspar, and metallic oxides and sulfides (for example, goethite and pyrite); localized thin beds of peat and carbonaceous material also occur within the aquifer system (Hanshaw and others, 1971; Sprinkle, 1989; Katz and others, 1995b).

Celestite $\left(\mathrm{SrSO}_{4}\right)$ has been observed in small quantities in the Suwannee Limestone and upper part of the Avon Park Formation in well cuttings from Hardee and De Soto Counties; these cuttings did not contain any gypsum (McCartan and others, 1992b). Celestite also has been observed in core from a site in northwest central Florida, in association with gypsum in deeper parts of the Avon Park Formation (Cook and others, 1985).

The intermediate aquifer system has a more complex hydrogeology and mineralogy and is considerably more heterogeneous than the Upper Floridan aquifer. Other than calcite and dolomite in carbonate sections, quartz is abundant in siliciclastic deposits in the intermediate aquifer system. Other common minerals include clays (illite, smectite, sepiolite, palygorskite, and kaolinite), phosphatic minerals (apatite $\left[\mathrm{Ca}_{5}\left(\mathrm{PO}_{4}\right)_{3}(\mathrm{~F}, \mathrm{Cl}, \mathrm{OH})\right]$, francolite $\left[(\mathrm{Ca}, \mathrm{Na})_{5}\left(\mathrm{PO}_{4}, \mathrm{CO}_{3}\right)_{3}(\mathrm{~F}, \mathrm{OH})\right]$, and amorphous phosphate), and pyrite (FeS 2 ) (Scott, 1988; McCartan and others, 1992a; Florida Geological Survey, written commun., 1993; Kauffman, 1994; Katz and others, 1995b). Celestite has been observed in small quantities in the Hawthorn Group in Hardee and De Soto Counties (McCartan and others, 1992b). Gypsum has not been reported in the intermediate aquifer system.

\section{Carbonate Minerals}

To elucidate geochemical processes in the ground water, it is necessary to define the stable carbon isotopic composition $\left({ }^{13} \mathrm{C}\right)$ of the carbonate minerals that interact with the water. Isotopic data are reported as ratios of the heavy to the light isotope (for example, ${ }^{13} \mathrm{C} /{ }^{12} \mathrm{C}$ ), relative to a standard, in delta $(\delta)$ notation:

$$
\delta_{\text {sample }}=1,000\left(\frac{R_{\text {sample }}}{R_{\text {std }}}-1\right)
$$

where $\mathbf{R}_{\text {sample }}$ and $\mathbf{R}_{\text {std }}$ are the ratio of the heavy to the light isotope in the sample and in the standard, respectively. Standards used in this report are Pee Dee belemnite (PDB) for carbon $\left(\delta^{13} \mathrm{C}\right)$, Cañon Diablo troilite (CDT) for sulfur $\left(\delta^{34} \mathrm{~S}\right)$, and Standard Mean Ocean Water (SMOW) for hydrogen $(\delta \mathrm{D})$ and oxygen $\left(\delta^{18} \mathrm{O}\right)$. Units are in parts per thousand, which is denoted as per mil.

The $\delta^{13} \mathrm{C}$ composition of calcite and dolomite in the Floridan aquifer system has been determined in previous studies to evaluate geochemical reactions and to better understand dolomitization and diagenetic processes (Hanshaw and Back, 1972; Cander, 1991). Values near 0 per mil indicate little change from seawater composition. Most reported $\delta^{13} \mathrm{C}$ values for calcite are near 0 per mil, and range between -0.4 and 3.1 per mil in the aquifer (Hanshaw and Back 1972; Sprinkle, 1989; Cander, 1991). The range of reported $\delta^{13} \mathrm{C}$ for dolomite is between -7.5 and 1.0 per mil, which is considerably greater than the range for calcite (Hanshaw and Back 1972; Sprinkle, 1989; Cander, 1991). Hanshaw and Back (1972) noted two groupings of dolomite based on isotopic composition, one which was near seawater composition and the other which was isotopically lighter than seawater (between -7.5 and -2.8 per mil). They hypothesized that lighter dolomites formed in the saltwater mixing zone.

Eight additional carbonate rock samples were analyzed for this study in order to obtain specific information from the study area. These included three limestone samples from carbonate sections of the Hawthorn Group, two limestone samples from the Suwannee Limestone, and three dolomite samples from the Avon Park Formation (fig. 5a). For most dolomite samples, $x$-ray diffraction analysis verified that dolomite was the only carbonate mineral present (John M. Neil, U.S. Geological Survey, written commun., 1994). The $\delta^{13} \mathrm{C}$ values for calcite 


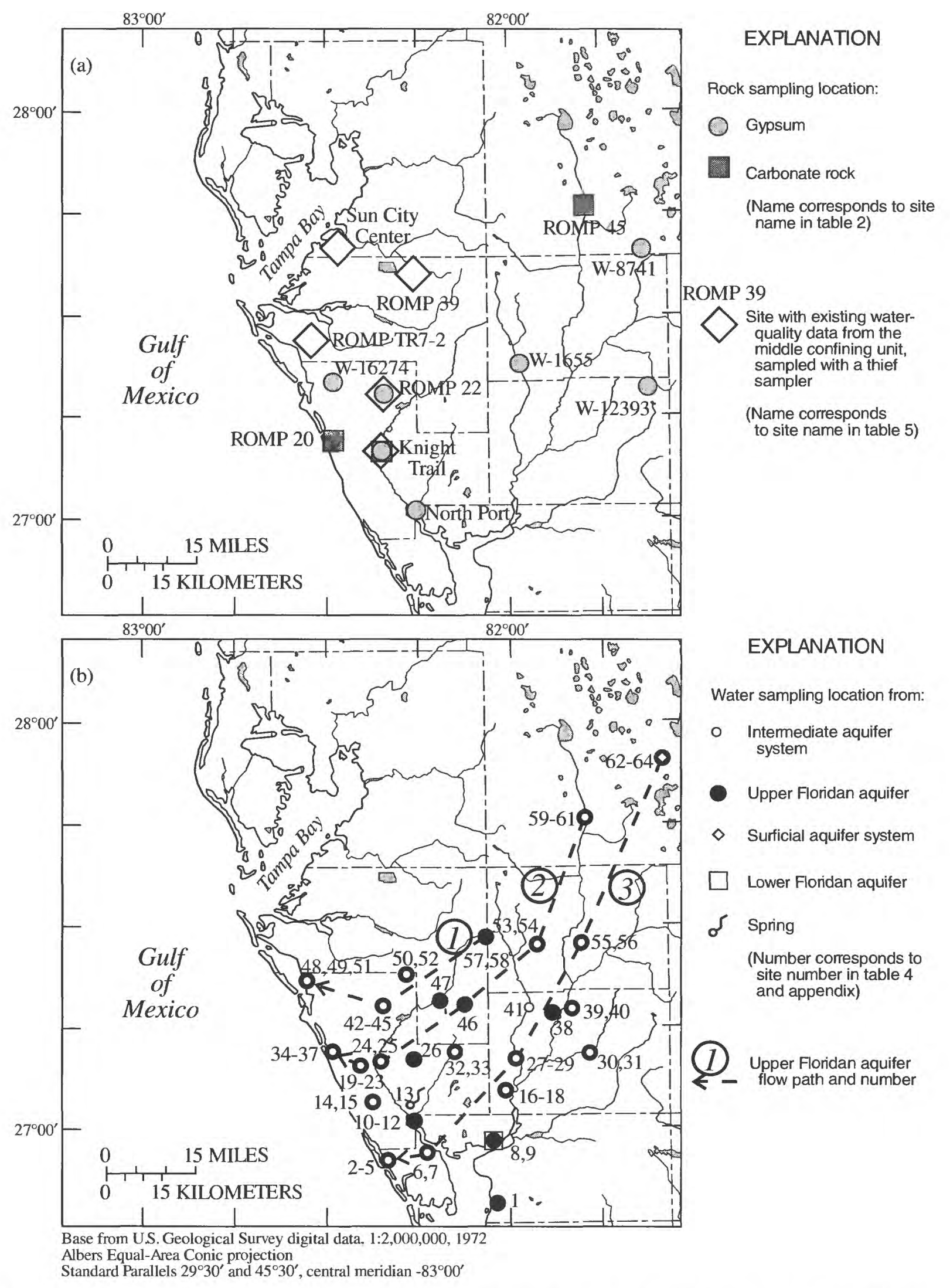

Figure 5. (a) Rock sampling locations and sites with existing water-quality data from the middle confining unit, and (b) water sampling locations and Upper Floridan aquifer flow paths. 
ranged from 1.9 to -7.1 per mil (table 2). The lighter values may be from caliche, which is deposited in root zones during periods when carbonate rocks are exposed above sea level (D. Budd, University of Colorado; oral commun., 1994). The $\delta^{13} \mathrm{C}$ values for dolomite ranged from 0.9 to 3.1 per mil (table 2). These values are distinctly different from the values for isotopically light dolomites observed by Hanshaw and Back (1972).

The ratio of strontium- 87 to strontium- 86 in seawater has varied over geologic time, particularly in the Tertiary (DePaolo and Ingram, 1985; Elderfield, 1986; Hess and others, 1986), which is the period when rocks were deposited that comprise the aquifer systems in southwest Florida. Because the ${ }^{87} \mathrm{Sr} /{ }^{86} \mathrm{Sr}$ ratio of rocks in the aquifer may differ from the seawater in which the rocks were deposited, ${ }^{87} \mathrm{Sr} /{ }^{86} \mathrm{Sr}$ was analyzed for several carbonate rock samples from the study area. This information is useful in evaluating ${ }^{87} \mathrm{Sr} /{ }^{86} \mathrm{Sr}$ ratios in ground water. For limestones, ${ }^{87} \mathrm{Sr} /{ }^{86} \mathrm{Sr}$ ratios were similar to that of seawater during the time of deposition (fig. 6; table 2). Limestone from the lower part of the Hawthorn Group (Tampa

Table 2. Isotopic composition of rock samples (Site locations shown in figure 5a) $\left[\delta^{34} \mathrm{~S}\right.$, delta sulfur-34; $\delta^{13} \mathrm{C}$, delta carbon-13; --, not analyzed]

\begin{tabular}{|c|c|c|c|c|c|}
\hline Site & $\begin{array}{c}\text { Depth } \\
\text { interval, feet }\end{array}$ & $\begin{array}{c}\text { Geologic } \\
\text { unit }\end{array}$ & $\begin{array}{c}\delta^{34} \mathrm{~S}^{1} \\
\text { per mil }\end{array}$ & $\begin{array}{c}\delta^{13} \mathbf{C}^{1} \\
\text { per mil }\end{array}$ & $\begin{array}{c}{ }^{87} \mathrm{Sr}^{86} \mathrm{Sr}^{2} \\
\text { ratio }\end{array}$ \\
\hline \multicolumn{6}{|l|}{ gypsum: } \\
\hline \multirow[t]{3}{*}{ North Port } & $1,900-1,920$ & Avon Park Formation & 24.1 & -- & -- \\
\hline & $2,340-2,350$ & Avon Park Formation & 23.0 & - & -- \\
\hline & $3,170-3,180$ & Cedar Keys Formation & 19.4 & -- & -- \\
\hline \multirow[t]{2}{*}{ Knight Trail } & $1,910-1,920$ & Avon Park Formation & 23.6 & -- & 0.70785 \\
\hline & 2,040 & Avon Park Formation & - & -- & 0.70778 \\
\hline W-8741 & $3,310-3,320$ & Cedar Keys Formation & 21.2 & -- & -- \\
\hline \multirow[t]{2}{*}{ W-1655 } & $1,886-1,896$ & Avon Park Formation & 20.0 & -- & -- \\
\hline & $3,115-3,130$ & Oldsmar Formation & 20.0 & -- & -- \\
\hline W-12393 & $3,010-3,020$ & Oldsmar Formation & 19.9 & & \\
\hline \multirow[t]{2}{*}{ W-16274 } & $1,320-1,340$ & Avon Park Formation & 24.8 & - & - \\
\hline & $1,800-1,820$ & Avon Park Formation & 23.6 & -- & -- \\
\hline ROMP 22 & $1,705-1,795$ & Avon Park Formation & 23.4 & -- & -- \\
\hline \multicolumn{6}{|l|}{ calcite: } \\
\hline \multirow[t]{2}{*}{ ROMP 45} & $130-135$ & Hawthorn Group & - & -1.5 & 0.70831 \\
\hline & $350-355$ & Suwannee Limestone & -- & -0.2 & 0.70792 \\
\hline \multirow[t]{3}{*}{ ROMP 20} & 91 & Hawthorn Group & -- & 1.9 & 0.70882 \\
\hline & 307 & Hawthorn Group & -- & -7.1 & 0.70813 \\
\hline & 506 & Suwannee Limestone & -- & -6.4 & 0.70800 \\
\hline \multicolumn{6}{|l|}{ dolomite: } \\
\hline ROMP 45 & $700-750$ & Avon Park Formation & -- & 0.9 & 0.70839 \\
\hline ROMP 20 & 1,106 & Ocala Limestone & -- & 1.2 & 0.70796 \\
\hline \multirow[t]{2}{*}{ Knight Trail } & $1,910-1,920$ & Avon Park Formation & -- & 3.1 & 0.70778 \\
\hline & 2,040 & Avon Park Formation & -- & -- & 0.70797 \\
\hline
\end{tabular}

\footnotetext{
${ }^{1}$ Isotope standards for analyses are Cañon Diablo troilite (CDT) for $\delta^{34} \mathrm{~S}$ and Pee Dee belemnite (PDB) for $\delta^{13} \mathrm{C}$.

${ }^{2}$ All data have been normalized to ${ }^{88} \mathrm{Sr} /{ }^{86} \mathrm{Sr}=0.1194$. NBS 987 is measured as 0.71024 .
}

Member of the Arcadia Formation) had a ${ }^{87} \mathrm{Sr} /{ }^{86} \mathrm{Sr}$ ratio in the range of Oligocene seawater. This is consistent with recent work by Missimer and others (1994) and Scott and others (1994) indicating that deposition of the lower Hawthorn Group occurred during the Oligocene, rather than the early Miocene. For dolomites, ${ }^{87} \mathrm{Sr} /{ }^{86} \mathrm{Sr}$ ratios were not necessarily the same as the ${ }^{87} \mathrm{Sr} /{ }^{86} \mathrm{Sr}$ ratio of seawater when the rocks were deposited. This is undoubtedly due to diagenetic changes during dolomitization, which can alter the ${ }^{87} \mathrm{Sr} /{ }^{86} \mathrm{Sr}$ of the rock (Moore, 1989). Dolomites from the Avon Park Formation sometimes had ${ }^{87} \mathrm{Sr} /{ }^{86} \mathrm{Sr}$ ratios similar to seawater during the Oligocene and Miocene, indicating some dolomitization occurred at a time later than the Eocene. In contrast, Cander (1991) concluded that most dolomitization of the Avon Park Formation occurred during the Eocene. 
Trace element concentrations in carbonate minerals in the Upper Floridan aquifer have been analyzed in previous studies to better understand processes controlling dolomitization and the diagenetic history of the rock (for example, Randazzo and Bloom, 1985; Cander, 1991). Elements present in trace levels in calcite and dolomite include strontium, sodium, iron, and manganese (Sprinkle, 1989). The average concentration of strontium in calcite is usually less than $500 \mathrm{ppm}$ and in dolomite is less than $250 \mathrm{ppm}$ (Randazzo and Hickey, 1978; Sprinkle, 1989; Cander, 1991; Budd and others, 1993). Calcite and dolomite in the Avon Park Formation have average iron and manganese concentrations that are less than $200 \mathrm{ppm}$ and less than $20 \mathrm{ppm}$, respectively (Cander, 1991). Sodium concentrations in calcite are less than $500 \mathrm{ppm}$ and in dolomite range from less than $500 \mathrm{ppm}$ to 2,000 ppm (Randazzo and Bloom, 1985).

\section{Gypsum}

Gypsum and anhydrite have not been reported from the intermediate aquifer system or the upper part of the Upper Floridan aquifer (within the Suwannee and Ocala Limestones). However, gypsum is more abundant at the base of the aquifer and within the middle confining unit, which corresponds to the middle to lower part of the Avon Park Formation. Because gypsum is a likely source for sulfate in the ground water, the isotopic and trace element composition of gypsum from the middle confining unit and the Lower Floridan aquifer was evaluated.

Limited data are available for the sulfur isotope composition of gypsum from the Floridan aquifer system (Rye and others, 1981; Sprinkle, 1989; Sacks, 1996), with $\delta^{34} S$ values ranging from 18.9 to 24.5 per mil. From within the study area, additional gypsum samples from the Floridan aquifer system were analyzed for $\delta^{34} \mathrm{~S}$, including seven samples from the Avon Park Formation, two from the Oldsmar Formation, and two from the Cedar Keys Formation. Locations of samples are shown in figure 5a, and results are listed in table 2. The sulfur isotope composition of gypsum from the Avon Park Formation (usually in the middle confining unit) ranged from 20.0 to 24.8 per mil. Values heavier than those reported by Rye and others (1981) (greater than 24 per mil) may be due to changes in extraction procedures and calibration standards since the early 1980's (W.C. Shanks, U.S. Geological Survey, written commun., 1995; Rees and others, 1978). Deeper samples from the underlying Oldsmar and Cedar Keys Formations (Lower Floridan aquifer and lower confining unit of the Floridan aquifer system) were slightly lighter, ranging from 19.4 to 21.2 per mil. (Analytical uncertainty according to the laboratory is about 0.5 per mil.)

The $\delta^{34} \mathrm{~S}$ of Eocene-age gypsum from the Avon Park Formation is isotopically heavier than expected for evaporites deposited from Eocene seawater (about 20 per mil; Claypool and others, 1980). Gypsum that is isotopically heavier than seawater probably is the result of localized sulfate reduction in brines from which the gypsum precipitated. Sulfur is fractionated during sulfate reduction. The reduced sulfur is enriched in the lighter isotope (sulfur-32), and isotopically heavier sulfate remains in solution. In core descriptions, zones of pyrite, organic material, and plant remains are often reported in similar or adjacent depth intervals as evaporites (Southwest Florida Water Management District, written commun., 1995). This indicates that anaerobic conditions were present, although it is not known if these sediments were anaerobic at the time gypsum precipitated. Attempts to analyze the isotopic composition of sulfur in pyrite and peat were unsuccessful because sample size was too small (W.C. Shanks, U.S. Geological Survey, written commun., 1994).

The ratio of ${ }^{87} \mathrm{Sr} /{ }^{86} \mathrm{Sr}$ was analyzed for two gypsum samples from the Avon Park Formation (corresponding to the middle confining unit). These two samples had very similar strontium isotope ratios, within the range of seawater during the middle Eocene (0.7077 to 0.7079 ) (fig. 6; table 2).

Gypsum often contains trace amounts of ions that can substitute for calcium in normal lattice sites or reside in interstitial positions (Kushnir, 1980). Data were not previously available on trace element concentrations in gypsum and anhydrite from the Floridan aquifer system (Sprinkle, 1989). Thus, trace element concentrations were estimated for six samples from the Floridan aquifer system. Two duplicate samples were also analyzed. A visually pure sample of gypsum was crushed with a mortal and pestle, dried in a desiccator, and precisely weighed. The sample was then dissolved with a known volume of deionized water, acidified with $1 \mathrm{~mL}$ of 70 percent hydrochloric acid, and analyzed for selected dissolved cations and trace elements. An unacidified sample was analyzed for sulfate concentration to compare with the theoretical weight percent expected for gypsum and anhydrite. This can be used as an indicator of sample purity. The concentrations of dissolved constituents were related to $\mathrm{ppm}$ based on the original sample weight. Strontium was the most abundant trace element, with a 
Table 3. Concentration of selected constituents in gypsum

[ppm, parts per million; \%, percent; concentrations determined by dissolving visually pure sample of known weight into known volume of deionized water and analyzing water sample at laboratory using standard methods of Fishman and Friedman (1989); potassium, silica, and manganese all less than detection limit of 90, 9, and $1 \mathrm{ppm}$, respectively]

\begin{tabular}{|c|c|c|c|c|c|c|}
\hline \multirow{2}{*}{ Constituent } & \multirow{2}{*}{$\begin{array}{l}\text { Reporting } \\
\text { unit }\end{array}$} & \multicolumn{2}{|c|}{$\begin{array}{l}\text { Range of chemical } \\
\text { constituents }{ }^{1}\end{array}$} & \multirow{2}{*}{ Median } & \multirow{2}{*}{$\begin{array}{l}\text { Detection } \\
\text { limit }\end{array}$} & \multirow{2}{*}{$\begin{array}{c}\text { Mean differ- } \\
\text { ence } \\
\text { between } \\
\text { duplicate } \\
\text { analyses }^{2}\end{array}$} \\
\hline & & Minimum & Maximum & & & \\
\hline Magnesium & ppm & 120 & 1,400 & 570 & 90 & 28 \\
\hline Sodium & ppm & 90 & 380 & 150 & 90 & 21 \\
\hline Barium & ppm & 7 & 58 & 42 & 2 & 32 \\
\hline Iron & ppm & 5 & 32 & 17 & 4 & 6 \\
\hline Strontium & ppm & 480 & 2,000 & 1,200 & 1 & 310 \\
\hline Aluminum & ppm & 43 & 200 & 83 & 18 & 51 \\
\hline Lithium & ppm & 5 & 40 & 25 & 4 & 18 \\
\hline Calcium $^{3}$ & weight $\%$ & 9 & 31 & 15 & .01 & 2.0 \\
\hline Sulfate $^{4}$ & weight $\%$ & 56 & 75 & 70 & .01 & 1.6 \\
\hline \multicolumn{7}{|c|}{$\begin{array}{l}\text { ISix gypsum samples from Floridan aquifer system: W-16274 }(1,800-1,820 \mathrm{ft}) \text {, Knight Trail } \\
\text { ROMP } 22(1.705-1,795 \mathrm{ft}) \text {. North Port }(3.170-3,180 \mathrm{ft}), \mathrm{W}-12393(3,010-3,040 \mathrm{ft}) \text {, and W-1655 (1, } \\
\text { locations shown in figure } 5 \mathrm{a} \text {. } \\
{ }^{2} \text { For two sets of duplicate analyses. } \\
{ }^{3} \text { Theoretical weight percent is } 23 \text { for gypsum }\left(\mathrm{CaSO}_{4} \cdot \mathrm{H}_{2} \mathrm{O}\right) \text { and } 29 \text { for anhydrite }\left(\mathrm{CaSO}_{4}\right) \text {. } \\
{ }^{4} \text { Theoretical weight percent is } 56 \text { for gypsum and } 71 \text { for anhydrite. }\end{array}$} \\
\hline
\end{tabular}

median concentration of $1,200 \mathrm{ppm}$ (table 3 ). Other minor (usually less than $500 \mathrm{ppm}$ ) trace elements detected in gypsum included magnesium, sodium, barium, aluminum, lithium, and iron.

\section{GEOCHEMICAL AND ISOTOPIC COMPOSITION OF GROUND WATER}

Waters from the Upper Floridan aquifer and intermediate aquifer system were sampled for chemical and isotopic analysis. This information was used to evaluate sources of sulfate in the aquifers and other geochemical processes influencing the chemical and isotopic composition of ground water in the study area.

\section{Sampling Methods}

Sampling focused along three flow paths in the Upper Floridan aquifer (fig. 5b); these flow paths were based on predevelopment potentiometric-surface conditions. Additional samples were collected outside the flow paths for better spatial coverage and to better sample saltwater end members. Water was collected from wells completed at different depth intervals in the Upper Floridan aquifer and intermediate aquifer system. Precise depth intervals of sampled wells varied according to well availability. Whenever possi- ble wells with discrete open intervals were sampled. Samples were collected in both the recharge and discharge areas of the Upper Floridan aquifer, including samples in the saltwater mixing zone. In addition, saline water was sampled from the Lower Floridan aquifer and from a spring (Warm Mineral Springs); a sample also was collected from the surficial aquifer system in the recharge area of the Upper Floridan aquifer. Wells were not available from the middle confining unit, but existing water-quality data were compiled from this unit (fig. 5a). Sampling locations are shown in figure $5 \mathrm{~b}$. Open hole intervals of wells along flow paths are illustrated on figure 7 ; information about sampled wells is listed in table 4 .

Purging methods varied depending upon the type of well. Most of the wells sampled were monitoring wells, but some wells were used for private or public water supply or irrigation. For monitoring wells, at least three volumes of water were pumped prior to sampling, while field parameters (temperature, $\mathrm{pH}$, and specific conductance) were being measured. Supply and irrigation wells had high yielding pumps that were used routinely. For these wells, sampling commenced after field parameters stabilized. Samples were collected from as close to the well head as possible, prior to the holding tank. A submersible pump was used for sampling most wells. Exceptions are noted in the appendix. 


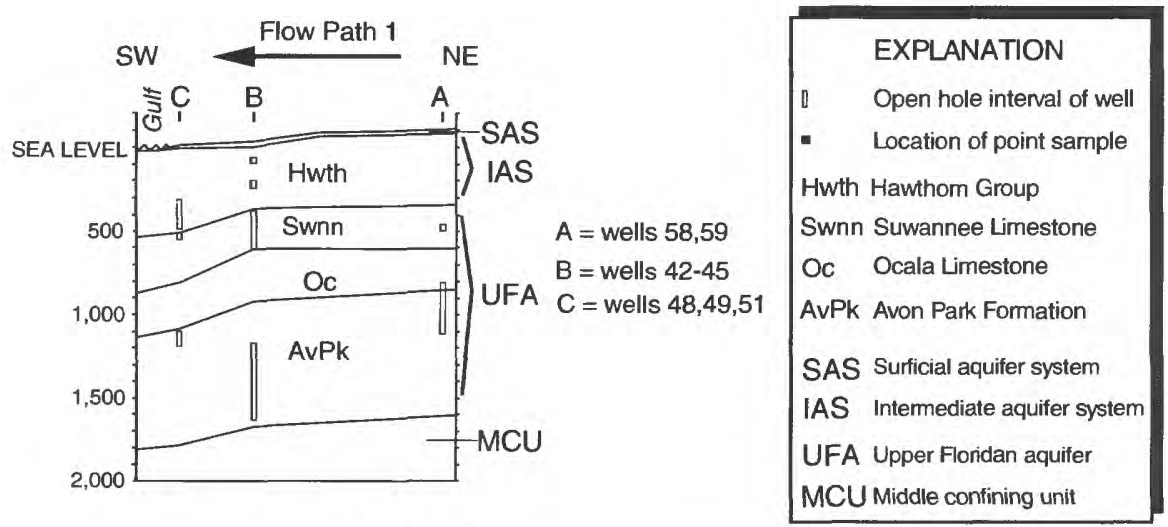

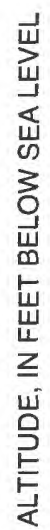
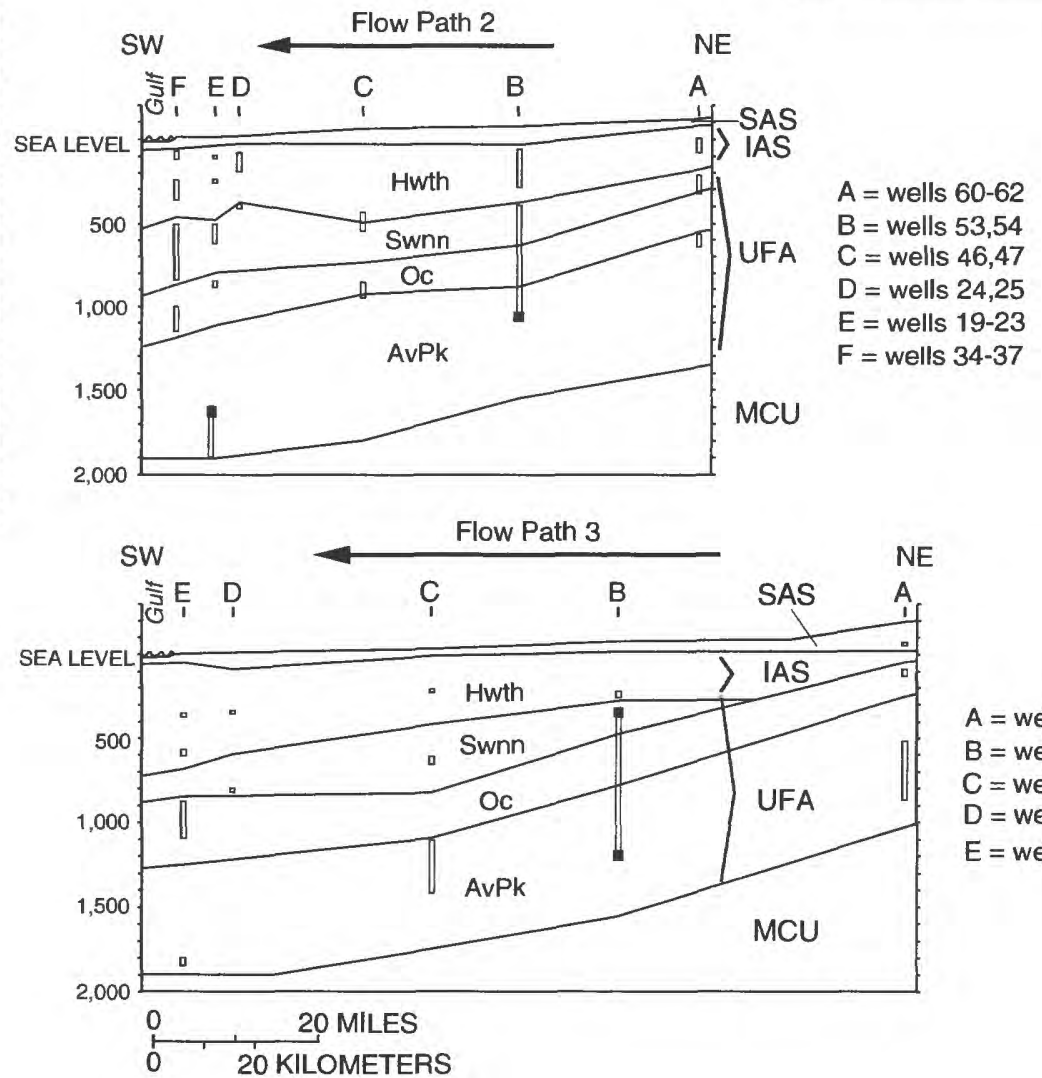

$A=$ wells $62-64$

$\mathrm{B}=$ wells 55,56

$\mathrm{C}=$ wells $27-29$

$\mathrm{D}=$ wells 6,7

$E=$ wells $2-5$

Figure 7. Cross sections along flow paths, showing open hole intervals of wells and lithologic and hydrogeologic units. (Locations of flow paths shown in figure 5b.)

diving to about $100 \mathrm{ft}$ and lowering weighted, rigid tubing another $100 \mathrm{ft}$. Samples were collected by pumping the tubing at the surface with a peristaltic pump. Samples for chloride and sulfate analysis were also collected from depths of $100 \mathrm{ft}$ and $60 \mathrm{ft}$ to examine stratification within the spring. Little stratification was observed (chloride was $9,500 \mathrm{mg} / \mathrm{L}$ at $60 \mathrm{ft}$ and $9,700 \mathrm{mg} / \mathrm{L}$ at $200 \mathrm{ft}$; sulfate concentrations were the same at the shallowest and deepest sampling interval).

\section{Determining Flow Zones for Wells with Large Open Hole Intervals}

Several Upper Floridan aquifer monitoring wells in Hardee and De Soto Counties had large open hole intervals (740 ft for well 39 (ROMP 26), $692 \mathrm{ft}$ for well 53 (ROMP 31 ), and $886 \mathrm{ft}$ for well 55 (ROMP 30); table 4). These wells were sampled because no other wells with shallow open-hole intervals were available in the area. Prior to sampling the wells, a vertical flow survey was done under static conditions to determine if distinct flow zones could be identified in the borehole. If so, a sample could be collected from a more discrete

For well 23, which is completed in a saline interval of the aquifer, purging of the well was not possible because of regulations regarding discharge of saline waters. Samples were collected using a thief sampler from a depth of $1,650 \mathrm{ft}$ (within the open borehole). The thief sampler was an electronically activated, 2-L sealed container that sampled at a specific depth. Because of the limited volume of sample, only selected chemical and isotopic analyses were done for this water.

For Warm Mineral Springs, a sample was collected from a $200 \mathrm{ft}$ depth in the spring vent by depth interval than from the entire borehole. The open hole interval of these wells was solely in the Upper Floridan aquifer, and each hole intersects the Suwannee Limestone, Ocala Limestone, and Avon Park Formation.

The heat-pulse flowmeter can detect low $(0.1 \mathrm{ft} / \mathrm{min})$ upward or downward flow within a borehole (Hess, 1990; Hess and Paillet, 1990; Crowder and others, 1994). The flow rate is determined by measuring the time for a pulse of heated borehole water to move to an upper or lower thermistor. Velocity values 
Table 4. Information about sampled wells and spring (Site locations shown in figure $5 b$ )

[AvPk, Avon Park Formation; Swnn, Suwannee Limestone; Hwth, Hawthorn Group; UFA, Upper Floridan aquifer; IAS, intermediate aquifer system; LFA, Lower Floridan aquifer; SAS, surficial aquifer system; --, not applicable]

\begin{tabular}{|c|c|c|c|c|c|c|}
\hline $\begin{array}{c}\text { Site } \\
\text { number }\end{array}$ & Name & $\begin{array}{c}\text { Site identification } \\
\text { number }^{1}\end{array}$ & $\begin{array}{l}\text { Casing } \\
\text { depth } \\
\text { (ft below land }\end{array}$ & $\begin{array}{c}\text { Well } \\
\text { depth } \\
\text { surface) }\end{array}$ & Aquifer & County \\
\hline 1 & Hot "Springs" (well) & 264923082013701 & ${ }^{2} 1,550$ & 1,900 & UFA & Charlotte \\
\hline 2 & ROMP TR3-3 AvPk & 265531082194801 & 1,602 & 1,652 & UFA & Charlotte \\
\hline 3 & ROMP TR3-3 Swnn & 265531082194803 & 680 & 900 & UFA & Charlotte \\
\hline 4 & ROMP TR3-3 Lower Hwth & 265531082194804 & 370 & 410 & IAS & Charlotte \\
\hline 5 & ROMP TR3-3 Upper Hwth & 265531082194805 & 155 & 177 & IAS & Charlotte \\
\hline 6 & ROMP TR3-1 Upper Hwth & 265638082130703 & 140 & 160 & IAS & Charlotte \\
\hline 7 & ROMP TR3-1 Swnn & 265638082130706 & 600 & 620 & UFA & Charlotte \\
\hline 8 & East Port MW2 & 265825082021201 & 2,249 & 2,330 & LFA & Charlotte \\
\hline 9 & East Port MW1 & 265825082021202 & 1,422 & 1,494 & UFA & Charlotte \\
\hline 10 & North Port Deep & 270058082152502 & 730 & 750 & UFA & Sarasota \\
\hline 11 & North Port Shallow & 270058082152503 & 560 & 600 & UFA & Sarasota \\
\hline 12 & North Port AvPk & 270140082152001 & 1,100 & 1,150 & UFA & Sarasota \\
\hline 13 & Warm Mineral Springs & 270333082154000 & -- & -- & -- & Sarasota \\
\hline 14 & Plantation Swnn & 270406082220102 & 630 & 650 & UFA & Sarasota \\
\hline 15 & Plantation Hwth & 270406082220103 & 66 & 180 & IAS & Sarasota \\
\hline 16 & GDU M-2 & 270540082001101 & 605 & 897 & UFA & De Soto \\
\hline 17 & GDU T-2 & 270540082001102 & 393 & 496 & IAS & De Soto \\
\hline 18 & General Development AvPk & 270554082003601 & 1,326 & 1,411 & UFA & De Soto \\
\hline 19 & ROMP TR5-2 Upper Hwth & 270919082234202 & 100 & 120 & IAS & Sarasota \\
\hline 20 & ROMP TR5-2 Lower Hwth & 270919082234203 & 245 & 265 & IAS & Sarasota \\
\hline 21 & ROMP TR5-2 Swnn & 270919082234205 & 510 & 630 & UFA & Sarasota \\
\hline 22 & ROMP TR5-2 Ocala & 270919082234206 & 850 & 890 & UFA & Sarasota \\
\hline 23 & Knight Trail ${ }^{3}$ & 270936082240901 & 1600 & 1,900 & UFA & Sarasota \\
\hline 24 & ROMP 19 WLAM & 270959082203001 & 400 & 425 & UFA & Sarasota \\
\hline 25 & ROMP19 WUAM & 270959082203002 & 87 & 205 & IAS & Sarasota \\
\hline 26 & ROMP19 EL.AM & 271021082151601 & 410 & 420 & UFA & Sarasota \\
\hline 27 & ROMP17 AvPk & 271026081583601 & 1,115 & 1,430 & UFA & De Soto \\
\hline 28 & ROMP 17 Swnn & 271026081583602 & 620 & 670 & UFA & De Soto \\
\hline 29 & ROMP 17 IAS & 271026081583604 & 220 & 240 & IAS & De Soto \\
\hline 30 & ROMP 16 Floridan & 271115081462701 & 757 & 942 & UFA & De Soto \\
\hline 31 & ROMP 16 Hwth & 271115081462702 & 300 & 340 & IAS & De Soto \\
\hline 32 & Big Slough & 271134082092201 & 78 & 100 & IAS & Sarasota \\
\hline 33 & ROMP 18 Swnn & 271137082074801 & 505 & 845 & UFA & Sarasota \\
\hline 34 & ROMP 20 Upper Hwth & 271137082284504 & 75 & 125 & IAS & Sarasota \\
\hline 35 & ROMP 20 Ocala-AvPk & 271137082284591 & 1,000 & 1,150 & UFA & Sarasota \\
\hline 36 & ROMP 20 Swnn & 271137082284592 & 500 & 840 & UFA & Sarasota \\
\hline 37 & ROMP 20 Lower Hwth & 271137082284593 & 250 & 370 & IAS & Sarasota \\
\hline 38 & Sorrell Groves & 271717081522601 & 511 & 893 & UFA & De Soto \\
\hline 39 & ROMP $26 \mathrm{AvPk}^{4}$ & 271757081493002 & 580 & 1,320 & UFA & De Soto \\
\hline 40 & ROMP 26 Hwth & 271757081493003 & 140 & 180 & IAS & De Soto \\
\hline 41 & Doyle Carlton & 271803081563401 & 126 & 300 & IAS & De Soto \\
\hline 42 & ROMP 22 AvPk & 271813082201391 & 1,200 & 1,660 & UFA & Sarasota \\
\hline 43 & ROMP 22 Swnn & 271813082201392 & 409 & 635 & UFA & Sarasota \\
\hline 44 & ROMP 22 Lower IAS & 271813082201393 & 228 & 272 & IAS & Sarasota \\
\hline 45 & ROMP 22 Upper IAS & 271813082201394 & 90 & 125 & IAS & Sarasota \\
\hline 46 & Edgeville & 271832082064801 & 487 & 600 & UFA & Manatee \\
\hline 47 & ROMP 23 AvPk & 271906082112401 & 904 & 1,000 & UFA & Manatee \\
\hline 48 & Sarasota Core Hole & 272042082322301 & 520 & 560 & UFA & Sarasota \\
\hline
\end{tabular}


Table 4. Information about sampled wells and spring (Site locations shown in figure 5b) --Continued

[AvPk, Avon Park Formation; Swnn, Suwannee Limestone; Hwth, Hawthorn Group; UFA, Upper Floridan aquifer; IAS, intermediate aquifer system; LFA, Lower Floridan aquifer; SAS, surficial aquifer system; --, not applicable]

\begin{tabular}{clrrrrr}
\hline $\begin{array}{c}\text { Site } \\
\text { number }\end{array}$ & \multicolumn{1}{c}{ Name } & $\begin{array}{c}\text { Site identification } \\
\text { number }\end{array}$ & $\begin{array}{c}\text { Casing } \\
\text { depth } \\
\text { (ft below land surface) }\end{array}$ & $\begin{array}{c}\text { Well } \\
\text { depth }\end{array}$ & Aquifer & County \\
\hline 49 & Sarasota Injection Monitor & 272053082320202 & 1,108 & 1,200 & UFA & Sarasota \\
50 & Verna 26 & 272248082164501 & 142 & 460 & IAS & Sarasota \\
51 & Ringling & 272253082332701 & 324 & 500 & IAS & Sarasota \\
52 & Verna 27 & 272256082163501 & 620 & 1,091 & UFA & Sarasota \\
53 & ROMP 31 AvPk & 272714081545901 & 460 & 1,152 & UFA & Hardee \\
54 & ROMP 31 Hwth & 272714081545902 & 125 & 355 & IAS & Hardee \\
55 & ROMP 30 AvPk & 272728081474701 & 380 & 1,266 & UFA & Hardee \\
56 & ROMP 30 Tampa & 272728081474702 & 280 & 316 & IAS & Hardee \\
57 & ROMP 32 AvPk & 272814082034801 & 909 & 1,215 & UFA & Manatee \\
58 & ROMP 32 Swnn & 272814082034802 & 560 & 600 & UFA & Manatee \\
59 & ROMP 45 Hwth & 274547081470901 & 110 & 192 & IAS & Polk \\
60 & ROMP 45 Swnn & 274547081470902 & 330 & 440 & UFA & Polk \\
61 & ROMP 45 AvPk & 274547081470903 & 680 & 757 & UFA & Polk \\
62 & ROMP 57A Floridan & 275348081335701 & 274 & 315 & UFA & Polk \\
63 & ROMP 57A Shallow & 275348081335703 & 114 & 134 & SAS & Polk \\
64 & City of Lake Wales & 275456081345501 & 705 & 1,050 & UFA & Polk \\
\hline
\end{tabular}

\footnotetext{
${ }^{1}$ Site identification number is composed of the latitude, longitude, and sequence number

${ }^{2}$ Estimated.

${ }^{3}$ Sample collected with thief sampler from $1,650 \mathrm{ft}$.

${ }^{4}$ Sample collected from drop pipe set between 1,245 and $1,250 \mathrm{ft}$.

${ }^{5}$ Sample collected from drop pipe set at $1,150 \mathrm{ft}$.

${ }^{6}$ Two sample collected from drop pipes set between 395 and $400 \mathrm{ft}$ and between 1,195 and 1,200 ft.
}

are determined from calibration data for tubes of similar diameter as the borehole under laboratory conditions (Hess and Paillet, 1990). A diverter was used to concentrate the flow in the borehole through the meter. Measurements were most accurate where the borehole was narrowest, allowing all of the flow to pass through the diverter to the meter.

Results from the flow survey are presented in figure 8. For well 39 , upward flow was detected in the entire borehole. This is consistent with the well's location in the aquifer discharge area. For well 53, upward flow was detected in most of the borehole. Based on predevelopment conditions, this well is near the transition between the aquifer recharge and discharge area. However, the well is currently considered to be in an area where recharge occurs from the intermediate aquifer system (Ryder, 1985; Aucott, 1988), which is consistent with measured head gradients between the intermediate aquifer system and the composite Upper Floridan aquifer. The upward flow may be caused by drawdown due to pumping in shallower parts of the aquifer. For well 55, downward flow was measured in the borehole to a depth of about $1,200 \mathrm{ft}$ (altitude about $1,150 \mathrm{ft}$ below sea level). Below this depth, slight upward flow was noted in the borehole. This well is in an area that changed from an aquifer discharge area prior to ground-water development to an aquifer recharge area (Ryder, 1985). Downward flow is consistent with drawdowns in the Upper Floridan aquifer, causing recharge from the overlying intermediate aquifer system.

To obtain as discrete a sample as possible, water samples were collected from wells 39 and 53 from the deepest flow zone (near the base of the open borehole) with a drop pipe pumped with a 2-inch submersible pump. For well 55, both the shallow and deep flow zone were sampled. Water quality from these two zones was virtually the same, indicating that the water in the borehole was well mixed.

\section{Sample Collection}

Standard USGS protocols were used for waterquality sampling (Wood, 1976). Temperature, $\mathrm{pH}$, and specific conductance were monitored using a flowthrough chamber so that the sample was isolated from the atmosphere. Water samples were collected after field parameters stabilized and sufficient volume was cleared 


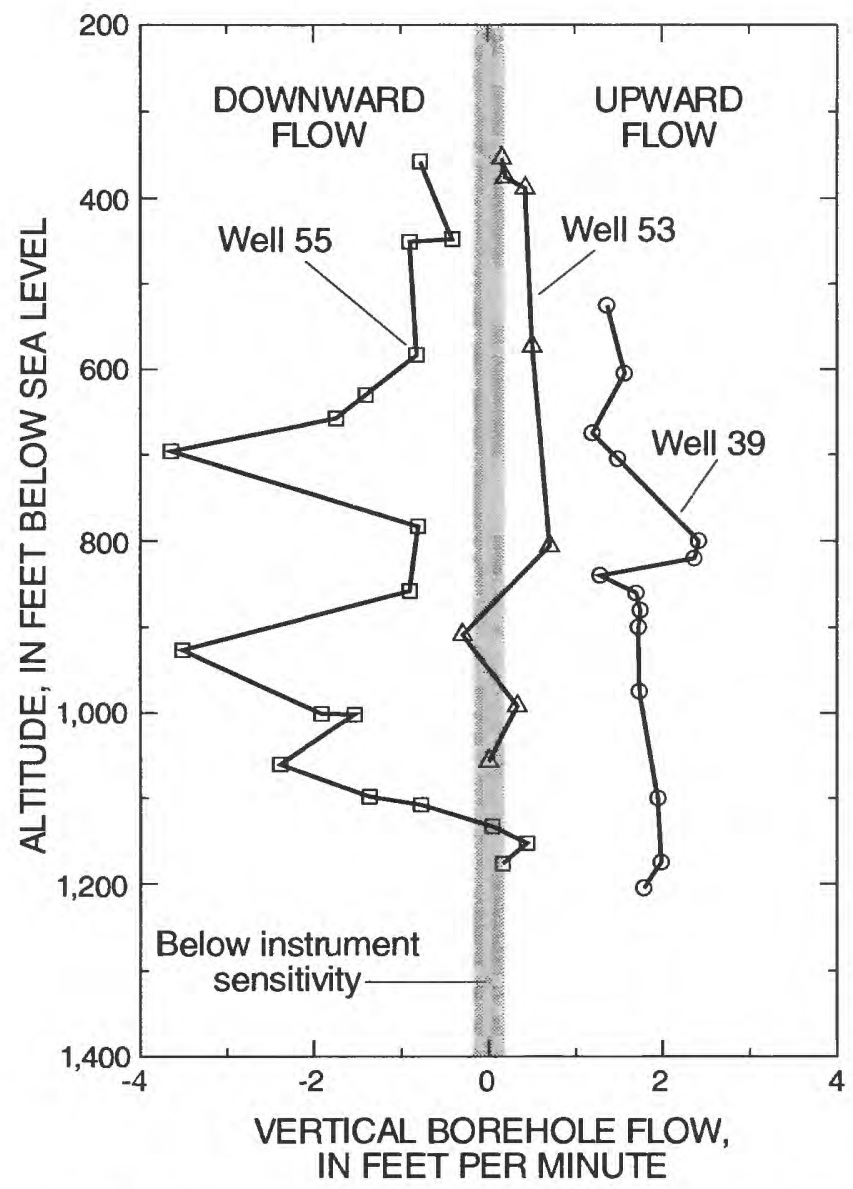

Figure 8. Profiles of vertical borehole flow under static conditions using the heat-pulse flow meter in wells 39 , 53 , and 55, which have large open hole intervals and are open exclusively to the Upper Floridan aquifer.

from the well (for monitoring wells). Alkalinity was determined in the field by titration with sulfuric acid. Sulfide was measured in the field using the methylene blue method and a field spectrophotometer (Hach, 1989). The detection limit for sulfide was $0.01 \mathrm{mg} / \mathrm{L}$; duplicate analyses were run for about one-third of the samples and typically were within 25 percent (average difference between duplicates was $0.15 \mathrm{mg} / \mathrm{L}$ ). Sulfide concentrations greater than $0.6 \mathrm{mg} / \mathrm{L}$ were diluted with deionized water in a volumetric flask. This may have oxygenated the sample and caused a slightly lower reading than was actually present (R. Carmody, U.S. Geological Survey, oral commun., 1994). When a well had not been sampled previously, sulfate concentration was estimated in the field with a spectrophotometer (with the barium sulfate method) to determine the method and amount of sample necessary for sulfur isotope collection of sulfate.

Samples were filtered through a $0.45 \mu \mathrm{m}$ filter for anion and cation analysis. Cation and trace metal samples, as well as samples for ${ }^{87} \mathrm{Sr} /{ }^{86} \mathrm{Sr}$ analysis, were collected in acid-washed bottles and acidified with $1 \mathrm{~mL}$ of 70 percent nitric acid. Nitrate samples were preserved with mercuric chloride. Dissolved organic carbon (DOC) samples were filtered through a $0.45 \mu \mathrm{m}$ silver filter in a stainless steel filter unit. Unfiltered samples were collected in glass bottles with polyseal caps for deuterium ( $\delta \mathrm{D})$ and oxygen-18 $\left(\delta^{18} \mathrm{O}\right)$ analysis of the water, and carbon-13 $\left(\delta^{13} \mathrm{C}\right)$ analysis of inorganic carbon. For $\delta^{13} \mathrm{C}, \mathrm{SrCO}_{3}$ was precipitated by adding approximately $50 \mathrm{~mL}$ of ammoniacal strontium chloride solution to a $500 \mathrm{~mL}$ unfiltered sample, minimizing exposure to the atmosphere.

Samples were collected for analysis of sulfur-34 $\left(\delta^{34} S\right)$ of sulfate and sulfide (if present). (In this report, total reduced sulfur species are referred to as sulfide; $\mathrm{H}_{2} \mathrm{~S}^{\circ}$ and $\mathrm{HS}^{-}$are the predominant species in the $\mathrm{pH}$ range of the samples). The method and amount of sample necessary for $\delta^{34} \mathrm{~S}_{\text {sulfate }}$ depended upon the sulfate concentration. If the sulfate concentration was greater than $20 \mathrm{mg} / \mathrm{L}$, at least $250 \mathrm{~mL}$ of sample (depending upon sulfate concentration) was acidified to a $\mathrm{pH}$ of about 4 with $1 \mathrm{~N} \mathrm{HCl}$, and immediately $\mathrm{BaCl}_{2}$ was added to precipitate the sulfate from solution as $\mathrm{BaSO}_{4}$. This precipitate was filtered, rinsed with deionized water, and dried before being sent to the laboratory. If the sulfate concentration was less than $20 \mathrm{mg} / \mathrm{L}, 20 \mathrm{~L}$ of acidified sample were pumped through an anion exchange column that previously was flushed with $\mathrm{KCl}$ and deionized water. In the laboratory, the sulfate was eluted from the resin by rinsing with $\mathrm{KCl} ; \mathrm{BaCl}_{2}$ then was added to the sample to precipitate $\mathrm{BaSO}_{4}$, as described for the high sulfate samples. For one sample (from well 62), which had a sulfate concentration less than $1 \mathrm{mg} / \mathrm{L}$, insufficient sulfate was obtained for $\delta^{34} \mathrm{~S}$ analysis.

For $\delta^{34} \mathrm{~S}_{\text {sulfide, }}$, the sample was collected in either one or a series of three 50-L carboys and was acidified with $100 \mathrm{~mL}$ of $6 \mathrm{~N}$ sulfuric acid so that $\mathrm{H}_{2} \mathrm{~S}^{\circ}$ was the predominant reduced sulfur species. Gaseous $\mathrm{H}_{2} \mathrm{~S}$ was stripped from the sample with ultra-high purity nitrogen gas (less than $10 \mathrm{ppm} \mathrm{O}_{2}$ ) in a system closed to the atmosphere. After leaving the carboy, the $\mathrm{H}_{2} \mathrm{~S}$ entered a solution of $\mathrm{AgNO}_{3}$ and precipitated as $\mathrm{Ag}_{2} \mathrm{~S}$. This $\mathrm{Ag}_{2} \mathrm{~S}$ was filtered and dried before being sent to the laboratory. For three samples with sulfide concentrations less than or equal to $0.05 \mathrm{mg} / \mathrm{L}$, insufficient sulfur was obtained for $\delta^{34} \mathrm{~S}_{\text {sulfide }}$ analysis. 


\section{Quality Assurance Samples}

For quality assurance purposes, duplicate samples were collected from four wells (see appendix), and four deionized water equipment blanks were collected. For duplicate samples, there was generally less than 7 percent difference between major ion concentrations and less than 30 percent difference between trace element concentrations (except for several analyses that had very low concentrations near the detection limit). For waters with high salinities, bromide had high analytical errors because of interferences with chloride. Ionic charge balances for all analyses were within 5 percent. For the isotopes, precision according to duplicate analyses was 0.15 per mil for $\delta^{18} \mathrm{O}, 1.5$ per mil for $\delta \mathrm{D}, 0.3$ per mil for $\delta^{13} \mathrm{C}$, 0.3 per mil for $\delta^{34} \mathrm{~S}_{\text {sulfate }}$, and 0.4 per mil $\delta^{34} \mathrm{~S}_{\text {sulfide }}$ (see appendix).

Deionized water equipment blanks were collected through field equipment in contact with sample water (peristaltic or submersible pump, filter unit, and tubing). The deionized water was also analyzed directly from its source in the laboratory. Most constituents were below detection limits for both types of samples. Constituents that were detected in the equipment blank were always near the detection limit, indicating that minimal contamination was introduced by the field equipment.

\section{Chemical Composition of Ground Water}

Sulfate concentrations varied widely over the study area. Water in the shallowest part of the Upper Floridan aquifer had sulfate concentrations ranging from $0.5 \mathrm{mg} / \mathrm{L}$ in the recharge area of Polk County to $1,800 \mathrm{mg} / \mathrm{L}$ near the coast in Sarasota County (see appendix; fig. 9a). Sulfate concentrations from the shallow part of the aquifer were above the drinking water standard of $250 \mathrm{mg} / \mathrm{L}$ in most of Sarasota and De Soto Counties, but concentrations were below the drinking water standard to the north in eastern Manatee, Hardee, and Polk Counties. Sulfate concentrations typically were higher in deeper parts of the aquifer, and ranged from 6.0 to $2,800 \mathrm{mg} / \mathrm{L}$. Waters with highest sulfate concentrations (greater than $1,800 \mathrm{mg} / \mathrm{L}$ ) were in coastal areas, where chloride concentrations were also high (greater than $1,000 \mathrm{mg} / \mathrm{L}$ ), indicating mixing with saltwater. At each sampling location, sulfate concentrations were lower in the intermediate aquifer than in the Upper
Floridan aquifer. In the intermediate aquifer system, sulfate concentrations ranged from $6.3 \mathrm{mg} / \mathrm{L}$ in Polk County to $1,700 \mathrm{mg} / \mathrm{L}$ near the coast in Sarasota County. Sulfate concentrations were less than $250 \mathrm{mg} / \mathrm{L}$ in the intermediate aquifer system in most of the study area, except near the coast in Sarasota County and in isolated inland locations (fig. 9b).

All ground waters contained measurable sulfide except for one upgradient sample (well 64 in the Upper Floridan aquifer). This water also did not have measurable dissolved oxygen. Microbially mediated sulfate reduction is the probable source for sulfide (Rye and others, 1981). Sulfide concentrations in the Upper Floridan aquifer ranged from less than 0.01 $\mathrm{mg} / \mathrm{L}$ to $2.5 \mathrm{mg} / \mathrm{L}$ (fig. 10a). The highest sulfide concentrations were in the Peace River Basin and in coastal areas of Sarasota County (west of the Myakka River). Sulfide concentrations typically were lower in the most saline ground water. The range and distribution of sulfide in the intermediate aquifer system $(0.05$ to $2.7 \mathrm{mg} / \mathrm{L}$ ) were similar to those in the Upper Floridan aquifer (fig. 10b).

Along the three flow paths, sulfate and chloride concentrations generally increased in a downgradient direction and with depth (fig. 11). Sulfate concentrations in the Upper Floridan aquifer increased above the drinking water standard before chloride (which also has a $250 \mathrm{mg} / \mathrm{L}$ standard). For flow paths 1 and 2, sulfate attained higher concentrations (often greater than 1,000 $\mathrm{mg} / \mathrm{L}$ ) upgradient of the saltwater mixing zone than for flow path 3. (For this report, the saltwater mixing zone is defined as the region where chloride concentrations are greater than or equal to $250 \mathrm{mg} / \mathrm{L}$, or about 1 percent modern seawater, and less than $19,000 \mathrm{mg} / \mathrm{L}$, the concentration in seawater.) The saltwater mixing zone for flow paths 1 and 2 was relatively distinct, and chloride concentrations increased rapidly with depth and proximity to the coast. In contrast, the zone of elevated chloride for the more southern flow path 3 was much larger. In the overlying intermediate aquifer system, sulfate concentrations increased rapidly near the end of flow paths 1 and 2 . In the lower permeable zone in these areas, sulfate concentrations were similar to those in the Upper Floridan aquifer. In comparison, sulfate concentrations remained low in the intermediate aquifer system for flow path 3 until the saltwater mixing zone. Chloride concentrations in inland areas were generally higher in the intermediate aquifer system (between 25 and $100 \mathrm{mg} / \mathrm{L}$ ) than in the Upper Floridan aquifer (less than $25 \mathrm{mg} / \mathrm{L}$ ). Near the coast and further to the south, chloride concentrations typically were higher in the Upper Floridan aquifer and increased with depth in both aquifers. 


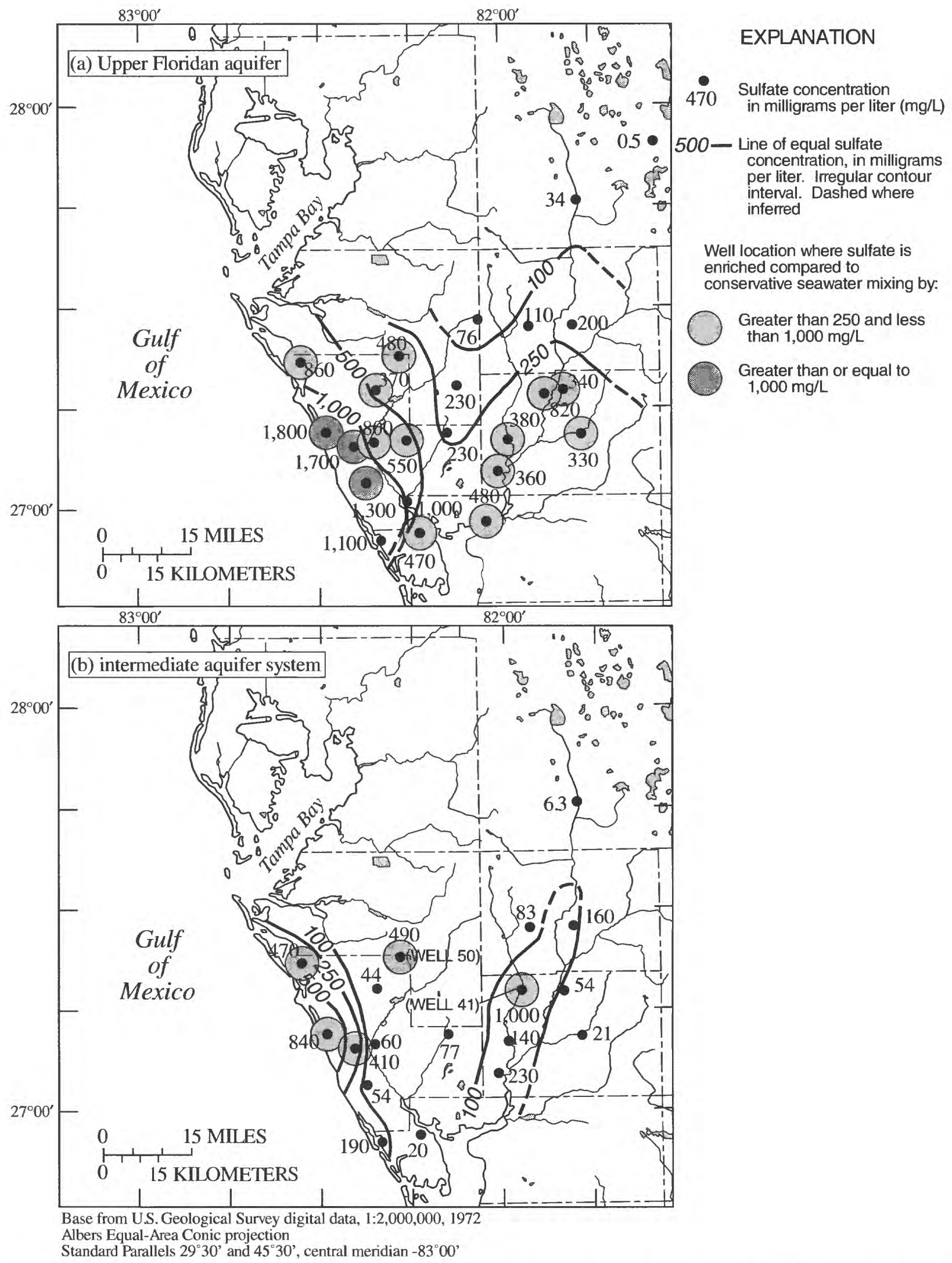

Figure 9. Sulfate concentrations in water from the shallowest sampling interval of (a) the Upper Floridan aquifer, and (b) the intermediate aquifer system, including areas where sulfate is significantly in excess of seawater mixing. 


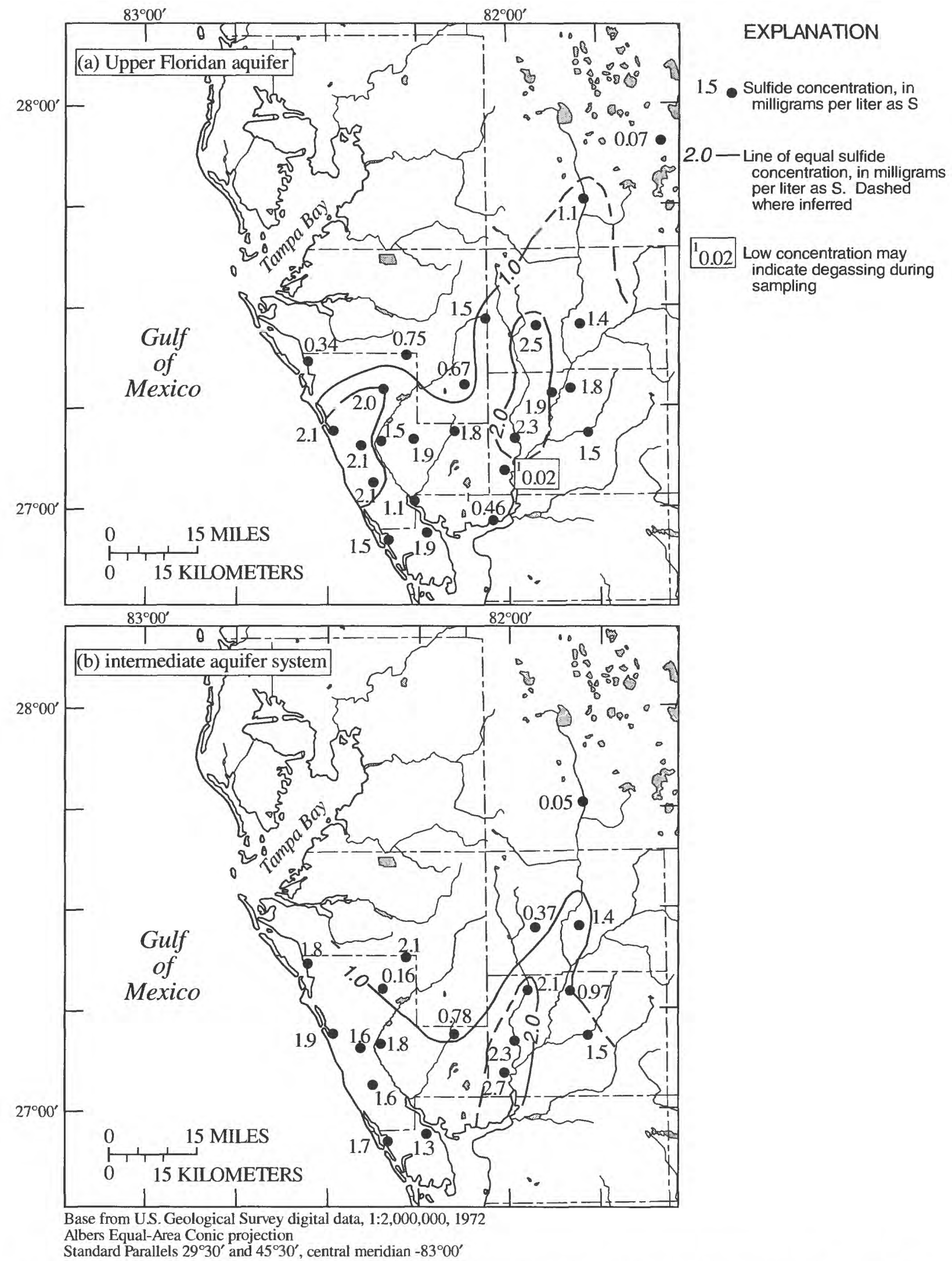

Figure 10. Sulfide concentration in water from the shallowest sampling interval of (a) the Upper Floridan aquifer, and (b) the intermediate aquifer system. 

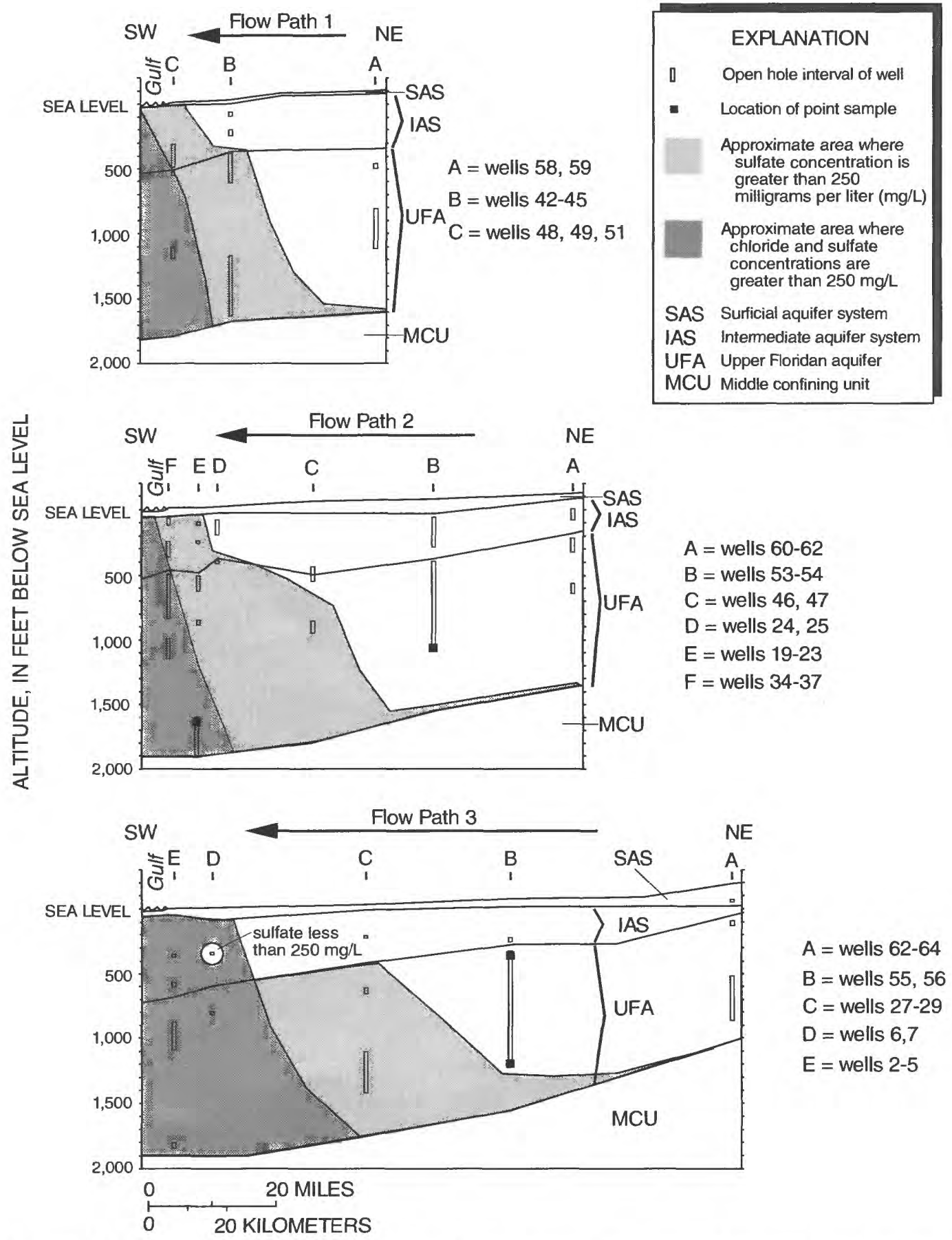

Figure 11. Cross sections along flow paths, showing approximate areas where sulfate and chloride concentrations exceed 250 milligrams per liter in water from the Upper Floridan aquifer and intermediate aquifer system. (Locations of flow paths shown in figure $5 \mathrm{~b}$.)

Reactions with aquifer minerals and saltwater mixing can influence solute concentrations in both aquifers. Selected major ions were plotted against chloride (assumed conservative and therefore an indicator of saltwater mixing) to illustrate differences between saltwater mixing and mineral dissolution (fig. 12). Sulfate concentrations increased by several orders of magnitude, whereas chloride concentrations remained low, indicating a mineral source for sulfate such as gypsum $\left(\mathrm{CaSO}_{4} \cdot \mathrm{H}_{2} \mathrm{O}\right)$. Chloride concentrations then increased by several orders of magnitude in the saltwater mixing zone, but sulfate concentrations remained high and fairly constant. Finally, at the highest chloride concentra- 

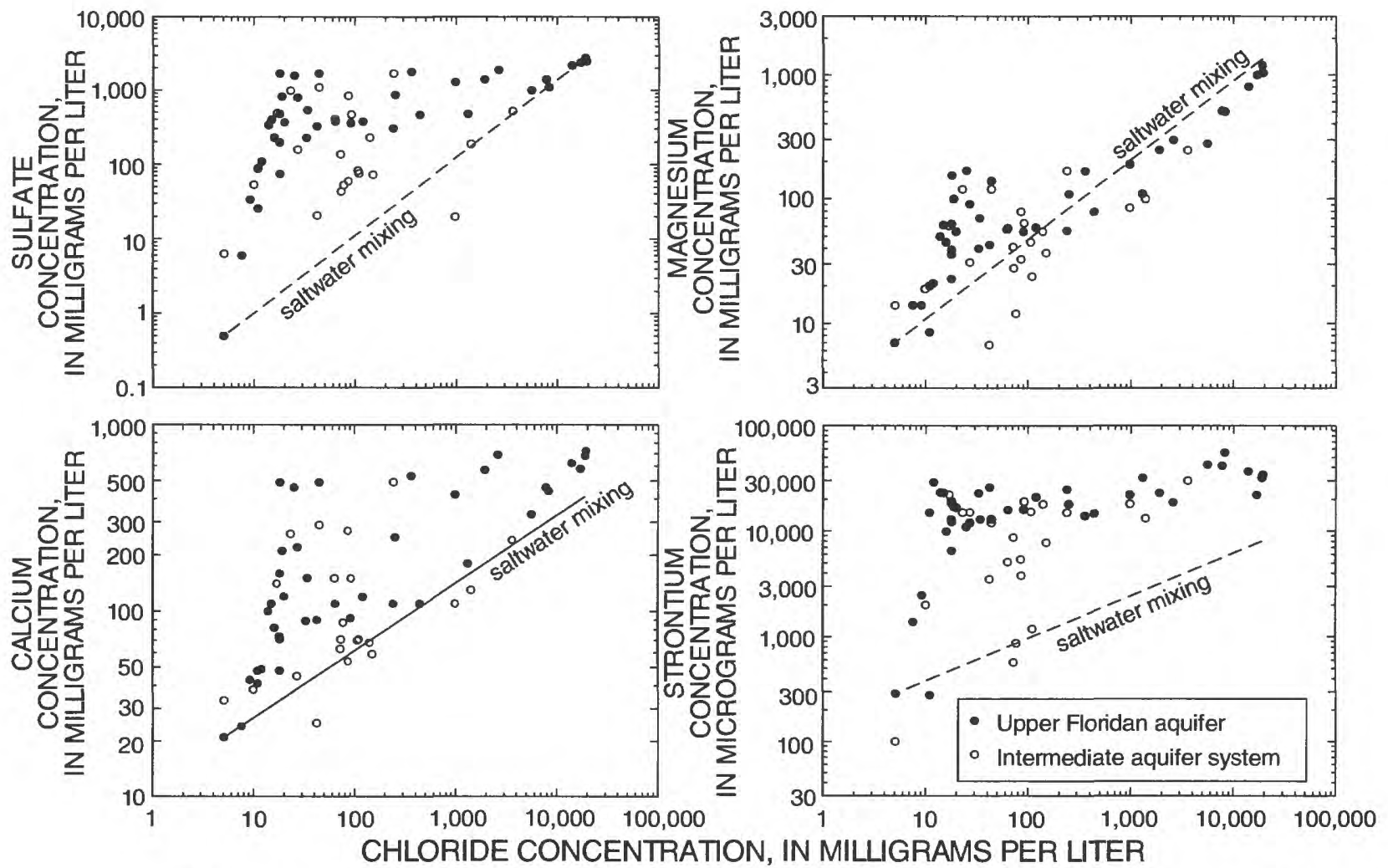

(Saltwater mixing line computed between upgradient water from well 62 and modem seawater from Hem, 1989.)

Figure 12. Relation between chloride concentration and concentrations of sulfate, calcium, magnesium, strontium, and sodium in water from the Upper Floridan aquifer and intermediate aquifer system.

tions, sulfate concentrations increased along the saltwater mixing line. Calcium concentrations were always elevated over saltwater mixing, and were highly correlated with sulfate $\left(\mathrm{r}^{2}=0.95\right.$ for both aquifers), suggesting a $\mathrm{CaSO}_{4}$ mineral source.

However, calcium-to-sulfate molar ratios were typically less than one, which is consistent with a sink for some of the calcium. Other mineral sources and sinks for calcium include calcite $\left(\mathrm{CaCO}_{3}\right)$ and dolomite $\left(\mathrm{CaMg}\left(\mathrm{CO}_{3}\right)_{2}\right)$. Magnesium concentrations were typically elevated over saltwater mixing at low chloride concentrations, indicating a mineral source such as dolomite. At higher chloride concentrations, magnesium concentrations also increased due to saltwater mixing. Strontium concentrations mimicked trends in sulfate and calcium concentrations. Strontium concentrations were very elevated before chloride concentrations increased, but then increased only slightly as chloride concentrations increased by three orders of magnitude in the saltwater mixing zone. Likely strontium sources are celestite $\left(\mathrm{SrSO}_{4}\right)$ and trace amounts of strontium in gypsum, calcite, and dolomite; aragonite is not present in these aquifers.

\section{Saturation State of Water with Respect to Minerals}

To examine which minerals can dissolve or precipitate within the aquifer systems, the saturation state of ground water with respect to selected mineral phases was computed with the aqueous speciation model WATEQ4F (Ball and Nordstrom, 1991). Information on mineral saturation states is useful for interpreting mineral controls on ion concentrations and for hypothesizing probable reactions for massbalance modeling. The saturation index (SI) is a measure of the departure from equilibrium of the water with respect to mineral phases.

$$
S I=\log \left(I A P / K_{T}\right)
$$

where IAP is the ion activity product of the components of the mineral phase, and $\mathrm{K}_{\mathrm{T}}$ is the solid phase solubility equilibrium product at the specified 
temperature. An SI value of zero, with an associated range of uncertainty, indicates the water is in equilibrium or saturated with respect to the mineral phase, a value less than zero indicates undersaturation (mineral dissolution is possible), and a value greater than zero indicates supersaturation (mineral precipitation is possible). Distribution of species that are sensitive to the oxidation state of the water were computed using the Eh value determined from sulfate and sulfide concentrations.

Calculation of equilibrium for carbonate minerals is dependent upon the accuracy of the chemical analysis and $\mathrm{pH}$ measurement. For calcite, equilibrium is assumed for SI values between -0.15 and 0.15 ; for dolomite, equilibrium is assumed for SI values between -0.3 and 0.3 . Most of the waters were saturated to supersaturated with respect to calcite (see appendix). For dolomite, the exact value for the equilibrium reaction constant $\left(\mathrm{K}_{\mathrm{r}}\right)$ is uncertain $(\mathrm{Hsu}$, 1963). Thus, SI values are reported for both "disordered" dolomite $\left(\log \mathrm{K}_{\mathrm{r}}\right.$ of -16.54) and "crystalline" dolomite ( $\log \mathrm{K}_{\mathrm{r}}$ of -17.09 ; Nordstrom and others, 1990). Most of the ground waters were undersaturated to saturated with respect to "disordered" dolomite and saturated to supersaturated with respect to "crystalline" dolomite (see appendix). Ground-water geochemistry and geochemical modeling studies have concluded that the $\mathrm{K}_{\mathrm{r}}$ for dolomite in the Floridan aquifer system is probably more similar to disordered dolomite than to crystalline dolomite $\left(\log \mathrm{K}_{\mathrm{r}}\right.$ between -16.6 and -16.7 ; Hsu, 1963; Hanshaw and others 1971; Plummer, 1977). This greater $\mathrm{K}_{\mathrm{r}}$ value is supported by data from this study because magnesium concentrations increase along flow paths in the Upper Floridan aquifer upgradient of the saltwater mixing zone, supporting dolomite dissolution and undersaturation. No information is available on specific $\mathrm{K}_{\mathrm{r}}$ values for the intermediate aquifer system.

All of the waters in the Upper Floridan aquifer and intermediate aquifer system were undersaturated with respect to gypsum (equilibrium is assumed for SI values between -0.03 and +0.03 ) (fig. 13). Waters with high sulfate concentrations (greater than $1,500 \mathrm{mg} / \mathrm{L}$ ) and low chloride concentrations (less than $100 \mathrm{mg} / \mathrm{L}$ ) from western Sarasota County were closest to equilibrium with gypsum (SI value of about -0.1 ). Waters with high sulfate and chloride concentrations from the southern part of the study area were more undersaturated (SI value of about -0.5 ; fig. 13) because of their higher salinity and ionic strength.
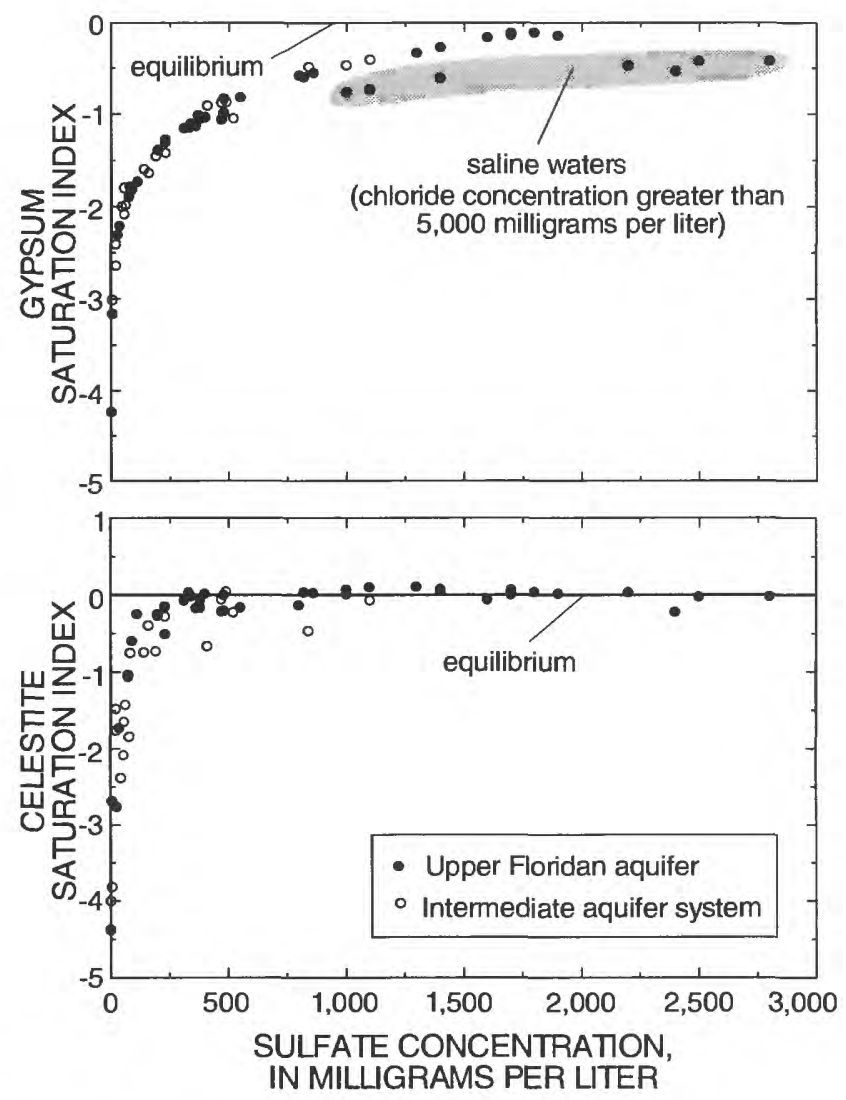

Figure 13. Relation between gypsum and celestite saturation index and sulfate concentration in water from the Upper Floridan aquifer and intermediate aquifer system.

Gypsum is more soluble in waters with ionic strengths similar to seawater, compared to fresher waters, because activity coefficients are lower (the ionic strength effect; Pankow, 1991). Thus, even though the saline waters had higher sulfate concentrations, the waters were more undersaturated with respect to gypsum than inland high sulfate waters.

Most ground waters with sulfate concentrations greater than $250 \mathrm{mg} / \mathrm{L}$ were near equilibrium with respect to celestite $\left(\mathrm{SrSO}_{4}\right)$ (fig. 13). At higher sulfate and strontium concentrations, waters remained near saturation with respect to celestite because of higher ionic strengths. Saline waters also were near equilibrium with celestite. The constancy of the celestite saturation index indicates that mineral equilibrium may control the concentration of strontium. McCartan and others (1992b) concluded that celestite dissolution and precipitation control strontium concentrations in Hardee and De Soto Counties, and that waters influenced by gypsum dissolution were saturated with respect to celestite. 
All ground waters were anoxic and were supersaturated with respect to pyrite; this mineral is unstable in oxidizing conditions. Most waters were undersaturated to saturated with respect to goethite (saturation is probably between SI values of 0.5 and 0.5 because of analytical uncertainties in iron concentrations).

The partial pressure of carbon dioxide $\left(\mathrm{P}_{\mathrm{CO}_{2}}\right)$ also was calculated with WATEQ4F (see appendix). In the Upper Floridan aquifer, $\mathrm{P}_{\mathrm{CO}_{2}}$ values were lowest in the recharge area, and increased in a downgradient direction. $\mathrm{P}_{\mathrm{CO}_{2}}$ values were highest near the coast in Sarasota County and in the lower Peace River Basin. Higher $\mathrm{P}_{\mathrm{CO}_{2}}$ values are probably related to longer aquifer residence times, which would allow for more extensive reactions with aquifer minerals and microbially mediated reactions which produce $\mathrm{CO}_{2}$. Saline ground waters from the southern-most part of the study area often had slightly lower $\mathrm{P}_{\mathrm{CO}_{2}}$ values than those of upgradient ground waters. In the intermediate aquifer system, $\mathrm{P}_{\mathrm{CO}_{2}}$ values were higher in inland areas, which corresponds to an area where bicarbonate concentrations were high, and in the lower permeable zone near the coast in Sarasota County.

\section{Water from the Upper Floridan Aquifer}

The chemical composition of water in the Upper Floridan aquifer follows the classic evolution of water in a carbonate aquifer (fig. 14) (Hanshaw and Back, 1979). In the upgradient recharge area, ground-water composition is dominated by calcium and bicarbonate. Down gradient in the discharge area, calcium, magnesium, and sulfate concentrations increase, which is consistent with gypsum and dolomite dissolution:

$$
\begin{aligned}
& \mathrm{CaSO}_{4} \cdot 2 \mathrm{H}_{2} \mathrm{O} \rightarrow \mathrm{Ca}^{2+}+\mathrm{SO}_{4}^{2-}+2 \mathrm{H}_{2} \mathrm{O} \\
& \mathrm{CaMg}\left(\mathrm{CO}_{3}\right)_{2} \rightarrow \mathrm{Ca}^{2+}+\mathrm{Mg}^{2+}+2 \mathrm{CO}_{3}^{2-}
\end{aligned}
$$

Further downgradient near the coast, the calcium-magnesium-sulfate dominated water mixes with saltwater in the aquifer, and ground-water composition evolves to a sodium chloride type.

In the freshwater part of the aquifer (generally less than about $250 \mathrm{mg} / \mathrm{L}$ of chloride or about 1 percent seawater), gypsum and dolomite dissolution and

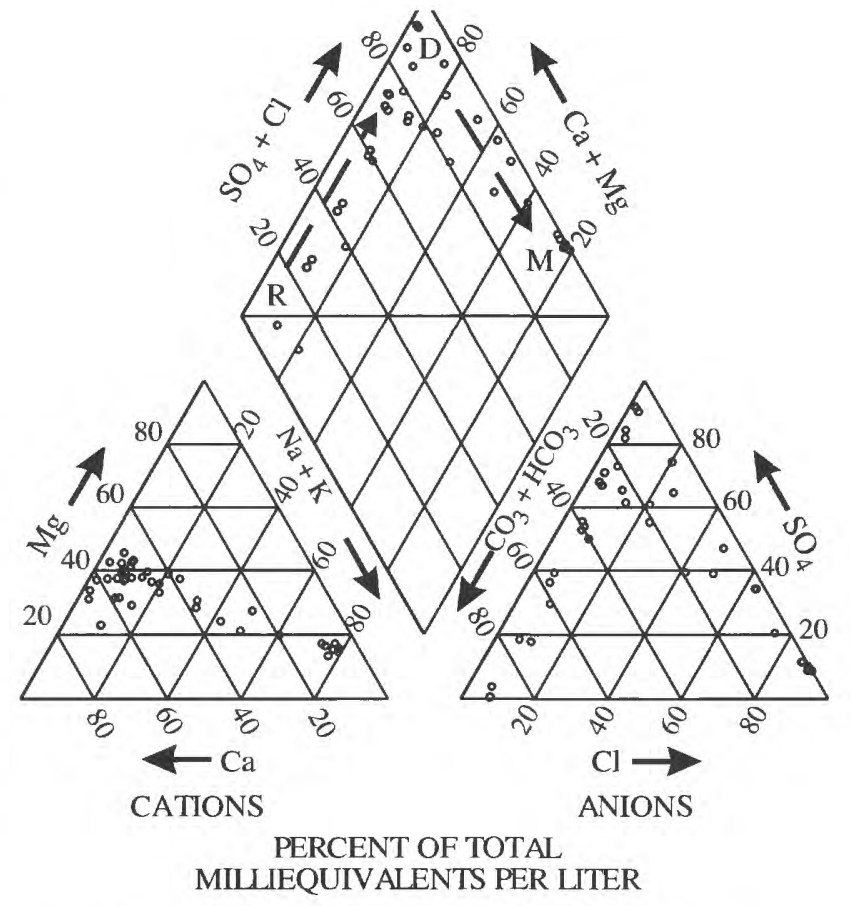

\section{EXPLANATION AND REACTION PATHS} (from Hanshaw and Back, 1979)

\section{R Recharge water, dominated by calcite dissolution \\ D Downgradient water, dominated by gypsum and dolomite dissolution \\ M Marine water \\ $\mathrm{R} \rightarrow \mathrm{D}$ Dedolomitization \\ $\mathrm{D} \rightarrow \mathrm{M}$ Dolomitization}

Figure 14. Chemical composition of water from the Upper Floridan aquifer.

calcite precipitation control ground-water composition. The combination of these three reactions is termed dedolomitization (Hanshaw and Back, 1979). Dedolomitization reactions are consistent with interpretations of the regional geochemical evolution of water in the aquifer in central and southwest Florida (for example, Back and Hanshaw, 1970; Plummer, 1977; Plummer and Back, 1980; Plummer and others, 1983; and Sprinkle, 1989). Water initially in equilibrium with calcite dissolves gypsum and dolomite. The additional calcium and carbonate in the water causes calcite to become supersaturated and to precipitate.

Evidence of dedolomitization reactions is illustrated by concurrent increases in calcium, magnesium, and sulfate concentrations in the shallow ground water along all three flow paths (fig. 15). Calcium and sulfate concentrations are highly correlated $\left(r^{2}=0.99\right)$, but the calcium-to-sulfate molar ratio is less than 1 (a 


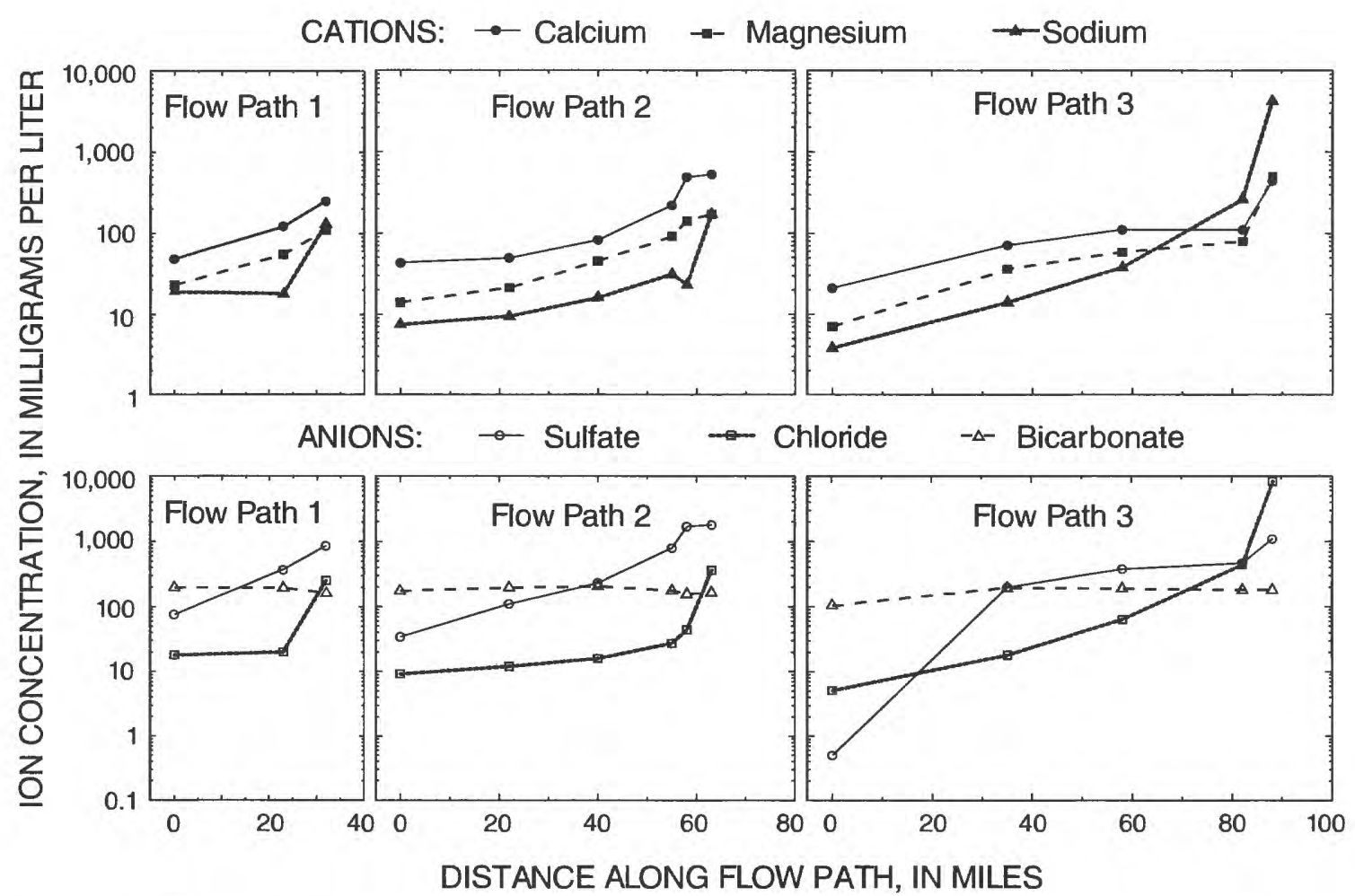

Figure 15. Changes in major ion concentrations in water from the shallowest sampling interval in the Upper Floridan aquifer along the flow paths. (Locations of flow paths shown in figure 5b.)

ratio of one is expected for gypsum dissolution only). This indicates that some of the calcium added to solution from gypsum is being removed (probably by calcite precipitation). Magnesium also is highly correlated with sulfate concentration $\left(r^{2}=0.96\right)$ for these low chloride waters. The molar ratio of calciumplus-magnesium to sulfate is approximately 1 , indicating that magnesium added to solution equals the calcium removed from solution (or dolomite dissolution is balanced by calcite precipitation). Bicarbonate concentrations decreased slightly along the flow paths (fig. 15), which is further evidence of calcite precipitation. Calcite precipitation in an aquifer with near neutral $\mathrm{pH}$ can be written as:

$$
\mathrm{Ca}^{2+}+\mathrm{HCO}_{3}^{-} \rightarrow \mathrm{CaCO}_{3}+\mathrm{H}^{+}
$$

The removal of calcium from solution during calcite precipitation should affect the saturation state of the water with respect to gypsum. This may explain the slight undersaturation with respect to gypsum (about $0.1)$ for high sulfate, low chloride waters (fig. 13a).

The dedolomitization reactions characteristic of waters in downgradient inland areas probably occur deep in the aquifer (Jones and others, 1993; Budd and others, 1993; Sacks and others, 1995). Gypsum, which occurs deep in the aquifer and within the middle confining unit, has not been detected in shallow parts of the aquifer. (It is possible that trace gypsum or anhydrite occurs at shallower intervals in the aquifer, but depositional environments were not conducive to the deposition of permanent evaporite minerals after the middle Eocene, when the Avon Park Formation was deposited (Cander, 1991).) Sulfate concentrations typically increase with depth in inland areas, which is consistent with a deep source for gypsum. Dolomite dissolution and calcite precipitation also probably occur deep in the aquifer near the gypsum (Budd and others, 1993), which is evidenced by calcium and magnesium concentrations increasing with depth. Further downgradient, upwelling (or upward flow) of water in discharge areas transports this deep, sulfaterich water to shallower zones in the aquifer before the saltwater mixing zone. Therefore, although dedolomitization reactions control concentrations of calcium, magnesium, and sulfate, the source of these ions in downgradient sections of the aquifer appears to be upwelling from deeper parts of the aquifer rather than reactions with aquifer minerals in shallow parts of the aquifer. 
Strontium has a complex distribution in the aquifer. Along the three flow paths, strontium concentrations initially increase rapidly (fig. 16). Further downgradient, strontium concentrations typically decrease slightly or the rate of increase declines markedly. This implies that the source of strontium changes or that mineral equilibrium controls the strontium concentrations. In upgradient parts of the aquifer (particularly in the Peace River Basin), sulfate concentrations are relatively low (less than $500 \mathrm{mg} / \mathrm{L}$ ) and strontium-to-sulfate molar ratios are high (greater than 0.1 ) (fig. 16). The lowest strontium-to-sulfate ratios (less than 0.01) are downgradient in coastal Sarasota County, where sulfate concentrations are very high (greater than 1,500 $\mathrm{mg} / \mathrm{L}$ ). Probable sources of strontium are celestite $\left(\mathrm{SrSO}_{4} ; \mathrm{Sr} / \mathrm{SO}_{4}\right.$ molar ratio of 1$)$, and trace concentrations in gypsum (up to 2,000 ppm, table 3; $\mathrm{Sr} / \mathrm{SO}_{4}$ molar ratio of about 0.003 ), calcite (less than $500 \mathrm{ppm}$ ), and in dolomite (less than 250 ppm) (Randazzo and Hickey, 1978; Sprinkle, 1989; Cander, 1991).

The distribution of strontium is probably controlled by celestite equilibrium (McCartan and others; 1992b). Celestite has been observed in small quantities in the Upper Floridan aquifer and intermediate aquifer system in Hardee and De Soto Counties (McCartan and others, 1992b). Waters with high strontium and low sulfate concentrations are undersaturated with respect to celestite, making dissolution possible. Downgradient in the aquifer where gypsum dissolution dominates the ground-water composition, high sulfate concentrations cause the waters to reach celestite saturation. Celestite precipitation could explain the slightly lower or more constant strontium concentrations downgradient in the aquifer. However, additional petrographic analysis is necessary to estab- lish whether celestite has actually precipitated in the aquifer. As ionic strengths increase, gypsum may contribute some additional strontium; the ratio of strontium-to-sulfate in the ground water in this area is similar to that in gypsum (table 3 ). In the saltwater mixing zone, strontium concentrations are somewhat higher, probably because the higher ionic strength waters can hold more strontium and sulfate before celestite equilibrium is reached. The variability in strontium concentrations also is probably complicated by local variability in the occurrence of celestite and by differences in strontium concentrations in gypsum, dolomite, and calcite.

\section{Brackish and Saline Ground Waters in Coastal Areas}

In coastal areas, water sampled from the Upper Floridan aquifer was generally brackish (dissolved solids concentration greater than $1,000 \mathrm{mg} / \mathrm{L}$ and less than $10,000 \mathrm{mg} / \mathrm{L}$ ) to saline (dissolved solids greater than $10,000 \mathrm{mg} / \mathrm{L}$ ). Brackish waters typically had elevated chloride concentrations (greater than or equal to $250 \mathrm{mg} / \mathrm{L}$ ) because of saltwater mixing. Besides chloride, the concentration of a number of other ions is strongly influenced by saltwater mixing (fig. 12). Reactions other than conservative saltwater mixing can be distinguished by computing enrichment or depletion of an ion relative to conservative mixing. Calculations were made assuming mixing between a dilute upgradient water in the recharge area (with a constant composition) and modern seawater. The fraction of seawater $(x)$ was computed using chloride as the conservative tracer:

$$
x=\left(C l_{g w}-C l_{u g}\right) /\left(C l_{s w}-C l_{u g}\right)
$$

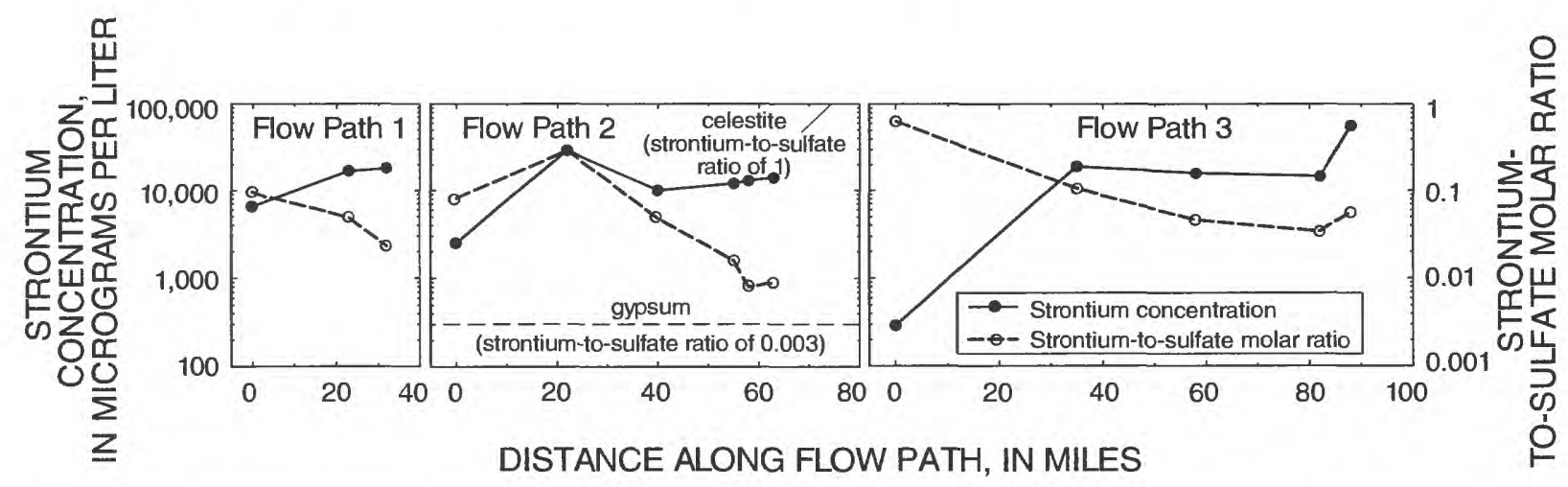

Figure 16. Changes in strontium concentration and strontium-to-sulfate molar ratio in water from the shallowest sampling interval in the Upper Floridan aquifer along the flow paths. (Locations of flow paths shown in figure $5 \mathrm{~b}$.) 
where $\mathrm{Cl}$ is the chloride concentration of the groundwater sample (gw), upgradient ground water (ug), and seawater (sw). Water from well 62 was used as the freshwater end member. An expected ion concentration was computed based on conservative mixing of the two end-member waters. In order to give insight into processes that deplete or enrich ions in the saltwater mixing zone and saline part of the aquifer, observed ion concentrations ( $\mathrm{i}_{\mathrm{obs}}$ ) were then compared to the expected ion concentration, given conservative mixing and the ion concentrations in modern seawater $\left(i_{\text {sw }}\right)(\mathrm{Hem}, 1989)$ and the upgradient ground water $\left(\mathrm{i}_{\mathrm{ug}}\right)$ :

$$
i_{e}=i_{o b s}-\left[\left(i_{s w} x\right)+\left(i_{u g}(1-x)\right)\right.
$$

where $\mathrm{i}_{\mathrm{e}}$ is ion enrichment if positive and ion depletion if negative.

Sulfate is enriched in the Upper Floridan aquifer compared to conservative saltwater mixing in most of the study area (fig. 9a). The amount of sulfate enrichment increases with depth in the aquifer and toward the coast, which is consistent with gypsum dissolution at depth and coastal upwelling from these deeper parts of the aquifer. Sulfate is significantly enriched in coastal Sarasota County and in the lower Peace River Basin. Sulfate is less enriched in the most saline ground waters, particularly in the southwestern part of the study area. Seawater (of an unknown age) is the primary source of sulfate for these saline waters, which dissolved minimal amounts of gypsum. This is consistent with a shallow marine source because saline water from deep gypsum-bearing zones in the middle confining unit or the Lower Floridan aquifer should contribute additional sulfate to the water. Saline waters from the Upper Floridan aquifer had significantly lower sulfate concentrations (about 2,600 $\mathrm{mg} / \mathrm{L}$ ) than that expected for saline water in equilibrium with gypsum (about $4,300 \mathrm{mg} / \mathrm{L}$ ).

Calcium is enriched in waters from the saltwater mixing zone, compared to conservative saltwater mixing. At lower chloride concentrations (less than 5,000 $\mathrm{mg} / \mathrm{L}$ or about 25 percent modern seawater), calcium enrichment is related to sulfate enrichment (fig. 17a), indicating a gypsum source. However, at higher chloride concentrations, calcium enrichment is not related to sulfate enrichment (fig. 17a), which points to another source of calcium other than gypsum. To evaluate other sources and sinks of calcium in the aquifer, the calcium assumed to come from gypsum dissolution (which is equivalent to the amount of sulfate enrichment in millimoles per liter $(\mathrm{mmol} / \mathrm{L}))$ was subtracted from the total calcium enrichment. These saline waters also are depleted in magnesium and sodium. Cation exchange is a process that can result in the addition of calcium and depletion of sodium. Seawater has significantly higher sodium than calcium concentrations $(10,500 \mathrm{mg} / \mathrm{L}$ and $410 \mathrm{mg} / \mathrm{L}$, respectively). As sodium-rich seawater moves through the aquifer, it mixes with fresh, calcium-rich ground water. Because of the concentration difference, two sodium ions can replace one calcium ion on exchange sites $(\mathrm{X})$ in the aquifer:

$$
\mathrm{CaX}+2 \mathrm{Na}^{+} \rightarrow \mathrm{Ca}^{2+}+\mathrm{Na}_{2} \mathrm{X}
$$

The depletion of sodium and enrichment of calcium (after subtracting gypsum dissolution) follow trends similar to those expected for cation exchange (fig. 17b). Clay minerals that occur in minor amounts in the Floridan aquifer system are probable exchange sites; abundant exchange sites also are present in the overlying clays of the Hawthorn Group.

Magnesium usually is enriched compared to conservative saltwater mixing for lower chloride waters, and depleted relative to saltwater mixing for higher chloride waters (greater than about 25 percent modern seawater). Lower chloride waters also are enriched in sulfate and calcium, which is consistent with dedolomitization reactions (gypsum and dolomite dissolution and calcite precipitation; equations 3, 4, and 5). After subtracting the influence of gypsum dissolution for these waters, calcium is depleted and magnesium is enriched, as expected for dolomite dissolution and calcite precipitation (fig. 17c). For higher chloride waters, the trend in reversed: magnesium is depleted and calcium is enriched. Calcium/magnesium exchange is a probable reaction because magnesium concentrations are elevated over calcium concentrations in seawater but not in freshwater parts of the aquifer. Alternatively, magnesium could be lost from saline waters through dolomitization of calcite. In this reaction, calcium is added to solution in the same amount that magnesium is removed:

$$
\mathrm{Mg}^{2+}+2 \mathrm{CaCO}_{3} \rightarrow \mathrm{CaMg}\left(\mathrm{CO}_{3}\right)_{2}+\mathrm{Ca}^{2+}
$$

Calcium enrichment (after subtracting gypsum dissolution) and magnesium depletion generally follow this expected 1:1 molar relation (fig. 17c). These waters 

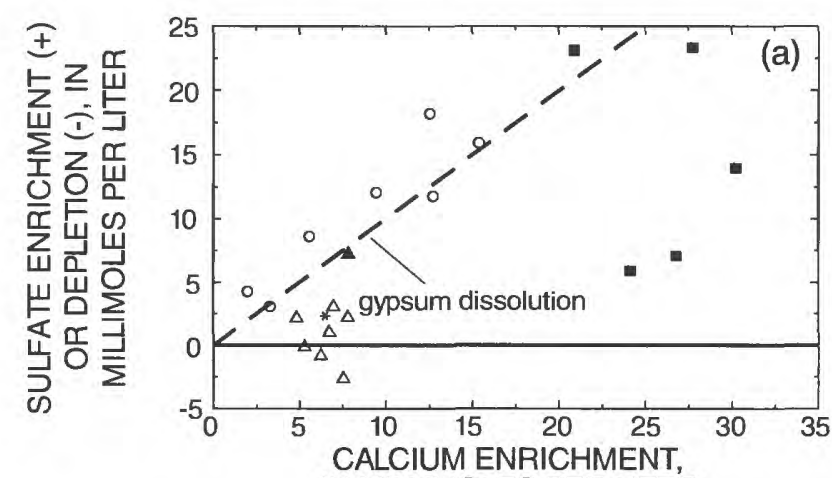

IN MILLIMOLES PER LITER
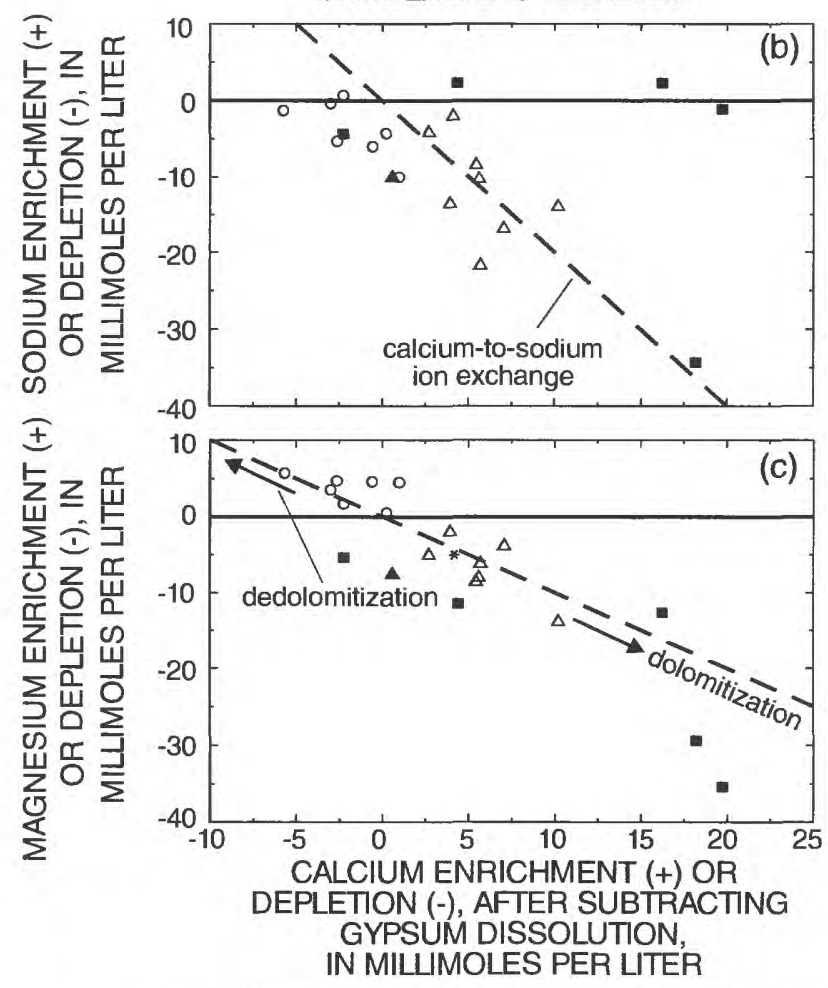

(Enrichment or depletion relative to conservative mixing between modem seawater and upgradient ground water from well 62.)

\section{EXPLANATION}

- Upper Floridan aquifer (chloride concentration greater than 250 and less than 5,000 milligrams per liter)

$\triangle$ Upper Floridan aquifer (chloride concentration greater than 5,000 milligrams per liter)

- Lower Floridan aquifer (well 8)

* Warm Mineral Springs

- Middle confining unit

Figure 17. Relation between enrichment or depletion of (a) sulfate and calcium, (b) sodium and calcium after gypsum dissolution, and (c) magnesium and calcium after gypsum dissolution, in water from the Upper Floridan aquifer with chloride concentration greater than or equal to 250 milligrams per liter, and water from the Lower Floridan aquifer, Warm Mineral Springs, and the middle confining unit. typically are near equilibrium or are supersaturated with respect to dolomite, and so dolomitization is possible. Dolomitization, however, is complex and not well understood (Hardie, 1987). Other studies of the Floridan aquifer system have concluded that some of the dolomite from the Floridan aquifer system formed in the saltwater mixing zone (Hanshaw and others, 1971; Randazzo and Hickey, 1978; Cander, 1991).

\section{Warm Mineral Springs}

Water from Warm Mineral Springs, a saline spring in southern Sarasota County (fig. 3), is similar in composition to saline waters from the Upper Floridan aquifer (fig. 17). This spring discharges from a doline feature over $200 \mathrm{ft}$ deep, and is unusual for a Florida spring because it is saline and anoxic. Kohout and others (1977) hypothesized that water discharging from Warm Mineral Springs originates from the Lower Floridan aquifer, representing deeply circulating saline water within the Florida carbonate platform. They theorized that this deep, geothermally heated water discharges along the central axis of the platform to shallower parts of the Floridan aquifer system. In contrast, Hutchinson (1992) concluded that Warm Mineral Springs discharges water from the Ocala-Avon Park permeable zone of the Upper Floridan aquifer because of similarities in water quality.

Data from this study support that the Upper Floridan aquifer is the source of water for Warm Mineral Springs. The sulfate concentration in the spring is not significantly enriched over conservative saltwater mixing, and the sulfate concentration is similar to that of saline waters in the Upper Floridan aquifer (fig. 17). If the water discharged from the Lower Floridan aquifer, the greater abundance of gypsum in the Lower Floridan aquifer and in the overlying middle confining unit should result in noticeably elevated sulfate concentrations over saltwater mixing (for example, the sulfate concentration in water from well 8, which is from the Lower Floridan aquifer, is significantly enriched compared to saltwater mixing; fig. 17).

In addition, the temperature of the spring water supports a shallower source than the Lower Floridan aquifer. Based on linear regression equations between well depth and water temperature $\left(\mathrm{r}^{2}\right.$ $=0.68$; standard error $=283 \mathrm{ft}$; intercept $=-4,092$; slope $=177)$ and casing depth and water tempera- 
ture $\left(\mathrm{r}^{2}=0.66 ;\right.$ standard error $=266 \mathrm{ft}$; intercept $=$ 3,768 ; slope $=160$ ) from this study, water from Warm Mineral Springs (temperature of 31.3 degrees C) probably originates from a depth between 1,250 and 1,450 ft deep. (The regressions excluded water collected with a thief sampler from well 23 , and water from wells 39,53 , and 55, which had large open hole intervals). This depth corresponds to saline intervals of the Upper Floridan aquifer, within the permeable zones of the Ocala Limestone and Avon Park Formation, as suggested by Hutchinson (1992), and is well above the Lower Floridan aquifer (about 2,000 ft deep based on Miller, 1986). A preferential conduit for flow, such as a fault or fracture plane, must be present in the subsurface to allow this deep Upper Floridan aquifer water to move to the surface.

\section{Evaluating Water from the Middle Confining Unit as a Source of Sulfate}

A possible source of sulfate in the Upper Floridan aquifer is diffusion of saline pore water from the middle confining unit. Water from the middle confining unit was not sampled during this study because wells were not available in this nonproductive zone. However, water samples were collected during exploratory drilling to the middle confining unit by SWFWMD at one site within the study area (ROMP 22) and two sites just north of the immediate study area (ROMP 39 and ROMP TR7-2 in Manatee County; fig. 5a). Water analyses were also available from a test hole in Sun City Center in southern Hillsborough County (Sinclair, 1979) and exploratory drilling of a deep injection site by a private consultant (Knight Trail; Law Environmental, Inc., 1989). Samples were collected from the bottom of the hole at all sites with a thief sampler; this water should be more representative of pore water within the unit than a pumped sample. Water pumped from similar zones usually was distinctly different because water was drawn from more permeable units. Thus, pumped samples were not considered to be representative of waters within the confining unit. Selected data from all sites are included in table 5.
Table 5. Water-quality data from the middle confining unit

[Samples were collected from bottom of hole with a thief sampler; units in milligrams per liter unless otherwise noted; $\mathrm{ft}$, feet; $\mu \mathrm{S} / \mathrm{cm}$, microsiemens per centimeter; SWF, Southwest Florida Water Management District (unpublished data); LEI, Law Environmental, Inc. (1989); Sincl., Sinclair (1979)]

\begin{tabular}{|c|c|c|c|c|c|}
\hline Parameter & ROMP 22 & $\begin{array}{l}\text { ROMP } \\
\text { TR7-2 }\end{array}$ & $\begin{array}{l}\text { Knight } \\
\text { Trail }\end{array}$ & $\begin{array}{l}\text { Sun City } \\
\text { Center }\end{array}$ & ROMP 39 \\
\hline $\begin{array}{l}\text { Depth (ft below } \\
\text { land surface) }\end{array}$ & 1,780 & 1,715 & 1,930 & 1,500 & 1,645 \\
\hline $\begin{array}{r}\text { Specific conduc- } \\
\text { tance }(\mu \mathrm{S} / \mathrm{cm})\end{array}$ & 94,300 & 54,400 & 48,000 & 79,600 & 25,860 \\
\hline Calcium & 1,700 & 1,600 & 1,500 & 1,700 & 1,000 \\
\hline Magnesium & 1,200 & 970 & 1,000 & 1,700 & 410 \\
\hline Sodium & 16.000 & 10,000 & 10,000 & 18,000 & 4,100 \\
\hline Potassium & 630 & 280 & 420 & 760 & 130 \\
\hline Chloride & 29,000 & 18,000 & 18,000 & 34,000 & 7,600 \\
\hline Sulfate & 4,800 & 3,900 & 4,800 & 5,400 & 3,300 \\
\hline $\begin{array}{l}\text { Bicarbonate } \\
\quad\left(\text { as } \mathrm{HCO}_{3}\right)\end{array}$ & 322 & 109 & 290 & 311 & 206 \\
\hline $\begin{array}{l}\text { Fraction modern } \\
\text { seawater }\end{array}$ & 1.53 & 0.95 & 0.95 & 1.79 & 0.40 \\
\hline Source of data & SWF & SWF & LEI & Sincl. & SWF \\
\hline
\end{tabular}

Water sampled from the middle confining unit was saline, with chloride concentrations ranging from 7,600 to $34,000 \mathrm{mg} / \mathrm{L}$ (fractions of seawater ranging from 0.40 to 1.79). Chloride concentrations were sometimes higher than modern seawater (ROMP 22 and Sun City Center). Sulfate concentrations ranged from 3,300 to $5,400 \mathrm{mg} / \mathrm{L}$. All waters from the middle confining unit were enriched in sulfate and calcium, compared to conservative dilution or concentration of seawater, which is consistent with gypsum dissolution. The waters also were saturated to slightly supersaturated with respect to gypsum (SI between 0.02 and 0.10 ). (For ionic strengths greater than $0.7, \mathrm{SI}$ values were calculated using PHRQPITZ; Plummer and others, 1988). Calcium was usually enriched over that expected from gypsum dissolution (fig. 17). The additional calcium may come from dolomitization, resulting in depletion of magnesium, or cation exchange, causing depletion of magnesium or sodium.

The high chloride concentrations indicate a marine origin for the water. However, the waters are not pure connate waters buried at the time of gypsum deposition because chloride concentrations are considerably lower than concentrations in a brine from which gypsum would precipitate. Seawater must be concentrated by a factor of about 3.5 to 5 before gypsum precipitation occurs, with a resultant chloride concentration greater than $66,000 \mathrm{mg} / \mathrm{L}$ (Drever, 1982). The connate water has undoubtedly been flushed out over time. Waters from the middle confining unit are probably mixtures between the original 
brine, later seawater that invaded the unit, and fresher water from the overlying Upper Floridan aquifer (Hickey, 1990).

Sulfate in the Upper Floridan aquifer likely does not originate from diffusion of saline pore waters in the middle confining unit. For example, at inland ROMP 22 (fig. 2), sulfate concentrations increased with depth in the Upper Floridan aquifer to greater than $1,500 \mathrm{mg} / \mathrm{L}$, but chloride concentrations remained low (less than $20 \mathrm{mg} / \mathrm{L}$ ). If sulfate diffused from the middle confining unit, chloride concentrations also would be expected to increase in the overlying aquifer, which clearly does not happen. Thus, the elevated sulfate concentrations in the Upper Floridan aquifer are from dissolution of gypsum near the base of the aquifer, within the freshwater flow system.

In coastal areas, chloride concentrations in the Upper Floridan aquifer were similar to seawater, and sulfate concentrations were not significantly in excess of conservative saltwater mixing (plus or minus $2.5 \mathrm{mmol} / \mathrm{L}$ or about $250 \mathrm{mg} / \mathrm{L}$; assuming 5 percent analytical uncertainty in terms to compute sulfate enrichment in equation 8 , and using error analysis methods described by Ramette, 1981). In contrast, waters from the middle confining unit were significantly enriched in sulfate ( 6 to $23 \mathrm{mmol} / \mathrm{L}$ or about 600 to $2,200 \mathrm{mg} / \mathrm{L}$; fig. 17). Thus, diffusion of pore water from the middle confining unit apparently is not a major source of sulfate to saline ground waters in the Upper Floridan aquifer. Rather, the saline water in the Upper Floridan aquifer in coastal areas appears to be relict seawater with a shallow source that did not dissolve gypsum in deeper parts of the aquifer system.

\section{Water from the Intermediate Aquifer System}

The chemical composition of water in the intermediate aquifer system is more varied than in the Upper Floridan aquifer (fig. 18). Most inland waters are either bicarbonate-dominated or mixed-ion type waters (fig. 19), with elevated sodium and chloride concentrations compared to inland waters from the Upper Floridan aquifer. Another group of waters is enriched in calcium, magnesium, and sulfate and is very similar to the dedolomitization waters from the Upper Floridan aquifer. These waters are in coastal Sarasota County where water discharges from the Upper Floridan aquifer to the intermediate aquifer system, or are in isolated inland locations (well 50 in northeast Sarasota County and well 41 in northwest De Soto County) (fig. 19). The third group of waters

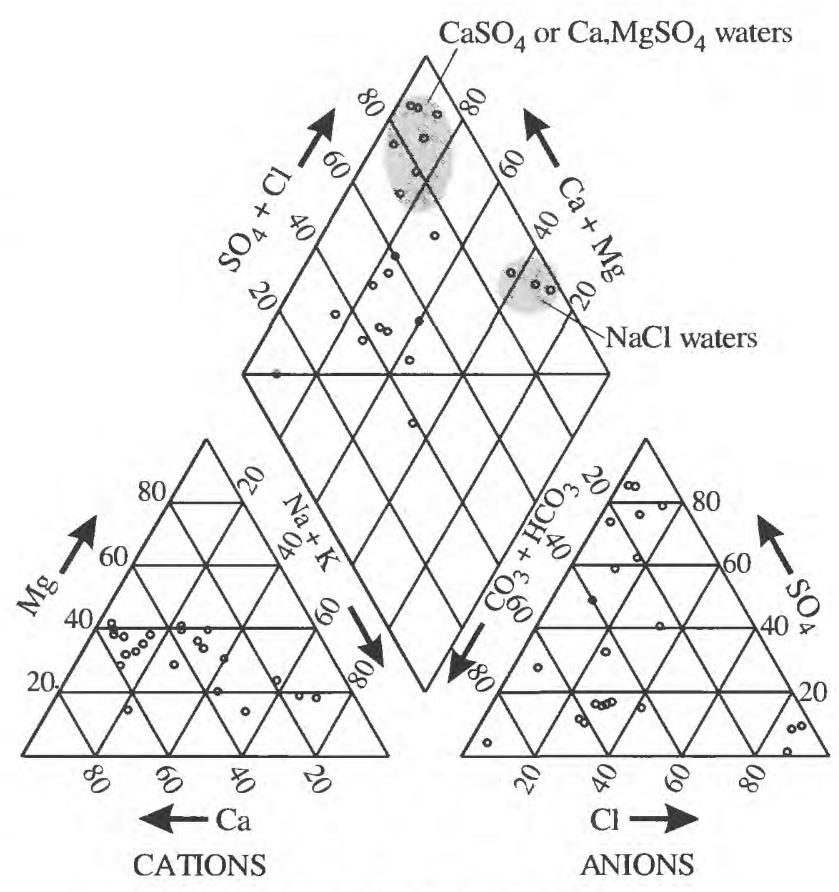

PERCENT OF TOTAL
MILLIEQUIVALENTS PER LITER

Figure 18. Chemical composition of water from the intermediate aquifer system.

is dominated by sodium and chloride and is from the southern part of the study area.

The bicarbonate and mixed-ion type waters from the intermediate aquifer system in inland areas are distinctly different than waters from the Upper Floridan aquifer. However, there is considerable variability in the composition of these waters. This is undoubtedly related to the heterogeneous lithology of the Hawthorn Group and to differences in the continuity of permeable zones. The intermediate aquifer system has more abundant clay minerals (for example sepiolite and smectites), siliciclastic minerals, and phosphatic minerals such as apatite (Scott, 1988; McCartan, 1992a) compared to the Upper Floridan aquifer. The aquifer also contains abundant calcite and dolomite (often as "dolosilts"; Scott, 1988), which usually are the dominant minerals in permeable zones where wells are completed. Besides reactions with aquifer minerals, inland waters in the intermediate aquifer system are influenced by recharge from the overlying surficial aquifer system.

Bicarbonate-dominated waters from eastern Sarasota and western Hardee Counties (water from wells $25,32,44,45$, and 53) had similar chemical compositions. These waters had elevated concentra- 


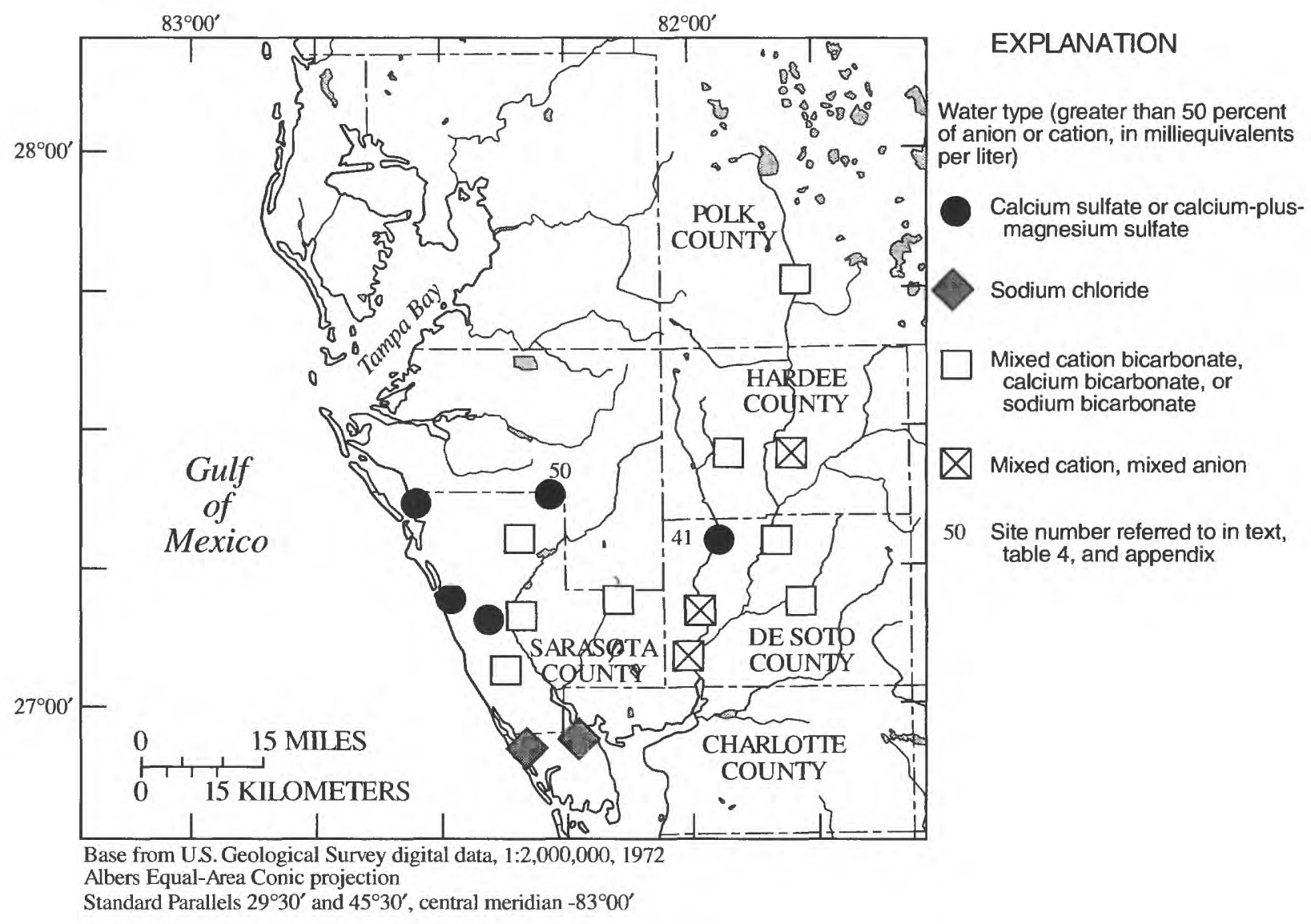

Figure 19. Major-ion water types from the intermediate aquifer system.

tions of bicarbonate (greater than $250 \mathrm{mg} / \mathrm{L}$ ), chloride (greater than $75 \mathrm{mg} / \mathrm{L}$ ), dissolved organic carbon (DOC) (often greater than $3.5 \mathrm{mg} / \mathrm{L}$ ), and silica (greater than $30 \mathrm{mg} / \mathrm{L}$ ), and usually had higher $\mathrm{P}_{\mathrm{CO}_{2}}$ values (greater than $10^{-2.0} \mathrm{~atm}$ ). The higher bicarbonate concentrations apparently are from more dissolution of carbonate minerals. This is illustrated by good relations between calcium-plus-magnesium and bicarbonate concentrations (calcite and dolomite dissolution) for the bicarbonate-dominated waters (fig. 20), with a slope similar to that of calcite and dolomite dissolution by carbonic acid (2:1 molar ratio):

$$
\begin{gathered}
\mathrm{CaCO}_{3}+\mathrm{H}_{2} \mathrm{CO}_{3} \rightarrow \mathrm{Ca}^{2+}+2 \mathrm{HCO}_{3}^{-} \\
\mathrm{CaMg}\left(\mathrm{CO}_{3}\right)_{2}+2 \mathrm{H}_{2} \mathrm{CO}_{3} \rightarrow \mathrm{Ca}^{2+}+\mathrm{Mg}^{2+}+4 \mathrm{HCO}_{3}^{-}
\end{gathered}
$$

Most waters from the intermediate aquifer system and Upper Floridan aquifer were close to equilibrium with respect to calcite. Therefore, the greater extent of carbonate dissolution, must be related to more dissolved

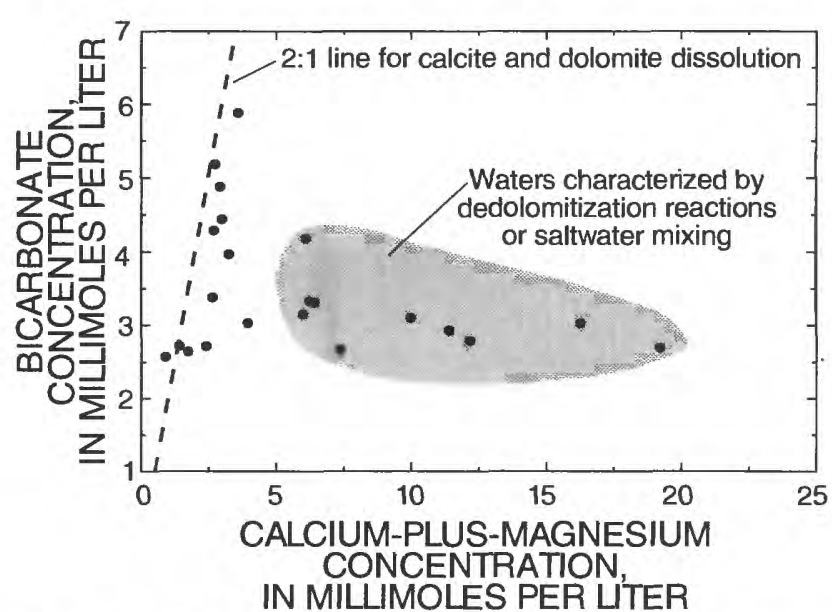

Figure 20. Relation between bicarbonate concentration and calcium-plus-magnesium concentration in water from the intermediate aquifer system, illustrating waters dominated by carbonate mineral dissolution compared to dedolomitization reactions and saltwater mixing.

$\mathrm{CO}_{2}\left(\mathrm{H}_{2} \mathrm{CO}_{3}\right)$, which would drive equations 11 or 12 further to the right.

Dissolved $\mathrm{CO}_{2}$ can be added to the water through microbial oxidation of organic matter (for example, sulfate reduction, iron reduction, or aerobic 
respiration in the surficial aquifer system before recharging the intermediate aquifer system). This would result in higher $\mathrm{P}_{\mathrm{CO}_{2}}$ values. The higher DOC concentrations could provide the additional carbon for microbial populations to oxidize. Conversely, the higher DOC concentrations may be the result of intermediate fermentation reactions during the oxidation of organic matter (Chapelle, 1993). The higher silica concentrations in these waters may be associated with the higher DOC concentrations. Several studies have shown that organic acids may enhance the dissolution of quartz and potassium feldspar (Bennett, 1991; McMahon and others, 1995). A positive relation between silica and DOC also was detected in anaerobic waters from the Upper Floridan aquifer in northwest central Florida (Sacks, 1996).

Many inland waters sampled from the intermediate aquifer system had elevated chloride concentrations compared to water from the Upper Floridan aquifer at the same site. Chloride could originate from less flushed seawater in clay beds in the aquifer system (Hobbie, 1993). However, Kauffman (1994) and Barr (1996) reported that pore water from clay units had very similar chloride concentrations to water from adjacent permeable zones of the aquifer system, indicating that seawater has been well-flushed from both units. Another possible source of chloride is dissolution of a chloride-containing mineral, such as chloride substituting for fluoride in apatite $\left(\mathrm{Ca}_{5}\left(\mathrm{PO}_{4}\right)_{3}(\mathrm{~F}, \mathrm{Cl}, \mathrm{OH})\right)$

(Wilson, 1977). However, chloride concentrations are typically more than an order of magnitude higher than fluoride concentrations, indicating that significant amounts of chloride are probably not added through mineral substitution. In addition, a good relation exists between chloride and bromide concentrations $\left(r^{2}=0.988\right)$ and chloride and sodium concentrations $\left(r^{2}=0.995\right)$, which is not consistent with such a mineral source. A more likely alternative for higher chloride concentrations is evaporative concentration during recharge to the water table in the overlying surficial aquifer system. Much of the area where chloride concentrations are elevated (for example, eastern Sarasota County) has standing water during the rainy season because of poorly drained soils and low topographic relief. This possibility is examined further in the section on deuterium and oxygen-18.

Upward leakage from the underlying Upper Floridan aquifer has a strong influence on the chemical composition of water in the intermediate aquifer system in coastal Sarasota County. These areas are characterized by high sulfate concentrations (greater than $250 \mathrm{mg} / \mathrm{L}$ in excess of saltwater mixing) (fig. $9 \mathrm{~b}$ ). The chemical composition of these waters is similar to Upper Floridan aquifer waters that are influenced by dedolomitization reactions. As a result, these high sulfate waters do not plot on the calcite equilibrium line in figure 20 because much of the calcium is from gypsum, and some bicarbonate is lost through calcite precipitation. Water from the lower permeable zone in western Sarasota County is most influenced by upward discharge and is chemically indistinguishable from shallow water from the Upper Floridan aquifer in the same area. These similarities indicate a hydraulic connection between the Upper Floridan aquifer and the intermediate aquifer system. However, the connection is probably through diffuse discharge (Ryder, 1985), rather than a continuous lack of confinement because a significant head difference exists between the Upper Floridan aquifer and the lower permeable zone of the intermediate aquifer system. (For example, the head in the Upper Floridan aquifer was about $10 \mathrm{ft}$ higher than the head in the lower permeable zone of the intermediate aquifer system during drilling of ROMP 20 (wells 34 through 37 ) in coastal Sarasota County; Southwest Florida Water Management District, written commun., 1992). Alternative paths for water and solutes to move between aquifers are through boreholes open to both aquifers (Hutchinson, 1992; Metz, 1996), vertical faults or fractures, and localized lack of confinement. Water from the upper permeable zone in coastal Sarasota County is also influenced by upward discharge from the Upper Floridan aquifer, but to a lesser degree than water in the lower permeable zone.

Waters from several inland wells have high sulfate concentrations characteristic of dedolomitization waters from the Upper Floridan aquifer (wells 41 and 50). Upward discharge between aquifers may be occurring in these areas. Well 50 is a supply well in Verna well field, and pumpage from both aquifer systems in the well field may cause discharge between aquifers. Conversely, well 50 may tap the very uppermost part of the Upper Floridan aquifer, and so the sample may not be representative of water solely from the intermediate aquifer system. Sulfate concentrations in the Upper Floridan aquifer in the Verna well field area are unusually high, which is probably the result of induced upwelling from pumping (Steinkampf, 1982; Hutchinson, 1984; Southwest Florida Water Management District, 1991). 
The high sulfate concentrations $(1,000 \mathrm{mg} / \mathrm{L})$ in water from well 41 in De Soto County also may be attributed to pumping and an interconnection between the Upper Floridan aquifer and intermediate aquifer system. Sulfate concentrations in the Upper Floridan aquifer in this area are high (greater than $500 \mathrm{mg} / \mathrm{L}$; Duerr and Enos, 1991). An upward head gradient exists between the aquifers in this area (Wilson, 1977; Duerr and Enos, 1991). The high sulfate concentration in the intermediate aquifer system is consistent with a source in the Upper Floridan aquifer. Water may locally move upward because of poorly confined conditions (for example, through naturally occurring fracture planes or because of locally absent clay beds). Alternatively, boreholes of wells open to both aquifers could cause high sulfate water to move from the Upper Floridan aquifer to the intermediate aquifer system (Duerr and Enos, 1991). Wells used for irrigation (the largest type of ground-water withdrawals in Hardee and De Soto Counties) are usually open to both aquifers in this area (Metz, 1995).

Localized high strontium concentrations (greater than $10,000 \mu \mathrm{g} / \mathrm{L}$ ) occur in the intermediate aquifer system in parts of Hardee and De Soto Counties, and in the lower permeable zone near the coast in western Sarasota and Charlotte Counties. The distribution of strontium in the intermediate aquifer system is probably influenced by both celestite dissolution and upward discharge from the Upper Floridan aquifer. Celestite $\left(\mathrm{SrSO}_{4}\right)$ has been observed in the intermediate aquifer system in Hardee and De Soto Counties (McCartan and others, 1992b). The ratio of strontium-to-sulfate is high in this area, supporting a celestite source for the strontium. Strontium may also enter the aquifer system by upward discharge from the Upper Floridan aquifer because of reduced heads in the intermediate aquifer system as water discharges to the Peace River. Near the coast in Sarasota County, the high strontium concentrations are probably related to discharge from the underlying Upper Floridan aquifer. The source of strontium in this area appears to be gypsum from the Floridan aquifer system, rather than celestite, because of low strontium-to-sulfate molar ratios, strong upward head gradients, and similar chemical composition to water in the Upper Floridan aquifer.

Three waters from the intermediate aquifer system from Charlotte County had high chloride concentrations (greater than $500 \mathrm{mg} / \mathrm{L}$; wells 4,5 , and 6). These waters are dominated by sodium and chloride, which is consistent with saltwater mixing (between 5 and 19 percent modern seawater). If the effects of saltwater mixing are removed (equation 8 ), the freshwater end member is similar to the bicarbonate-dominated waters discussed above (calcium, bicarbonate, and silica concentrations in excess of saltwater mixing), rather than dedolomitization waters characteristic of the waters in coastal Sarasota County. For well 6, chloride concentrations are higher than in the Upper Floridan aquifer well at the same site (well 7). Chloride concentrations could be high from a previous seawater inundation, which has not been flushed from the aquifer system. The higher heads in the underlying Upper Floridan aquifer may have kept the saltwater from migrating inland at greater depths. This intermediate aquifer system water also had an unusually low sulfate concentration, which was depleted relative to saltwater mixing. Sulfate reduction (and perhaps precipitation of a sulfide mineral) is a likely removal mechanism for sulfate.

\section{Isotopic Composition of Ground Water}

The isotopic composition of ground water can be helpful in understanding sources of water and solutes and identifying geochemical reactions. The stable isotopes of hydrogen (deuterium or $\delta \mathrm{D}$ ), oxygen (oxygen-18 or $\delta^{18} \mathrm{O}$ ), inorganic carbon (carbon-13 or $\delta^{13} \mathrm{C}$ ), and sulfur (sulfur-34 or $\delta^{34} \mathrm{~S}$ ) were analyzed. In addition, waters along flow path 2 and selected other waters were analyzed for the ratio of strontium87 to strontium- $86\left({ }^{87} \mathrm{Sr} /{ }^{86} \mathrm{Sr}\right)$. Results of the isotopic data are discussed in the following section.

\section{Deuterium and Oxygen-18}

Deuterium and oxygen-18 are influenced by processes affecting the water, rather than the solutes, and can help identify waters that have undergone evaporation, recharge under different climatic conditions than the present, and mixing of waters from different sources. The $\delta \mathrm{D}$ and $\delta^{18} \mathrm{O}$ composition of water from the Upper Floridan aquifer is indicative of mixing between recent recharge, older downgradient ground water, and saline water. The isotopically lightest waters were from the recharge area in Polk County ( $\delta \mathrm{D}$ around -13 per mil and $\delta^{18} \mathrm{O}$ around -2.6 per mil), and their values plot near the global meteoric water line (Craig, 1961) (fig. 21). Rainwater within Florida generally plots along the global meteoric water line, 


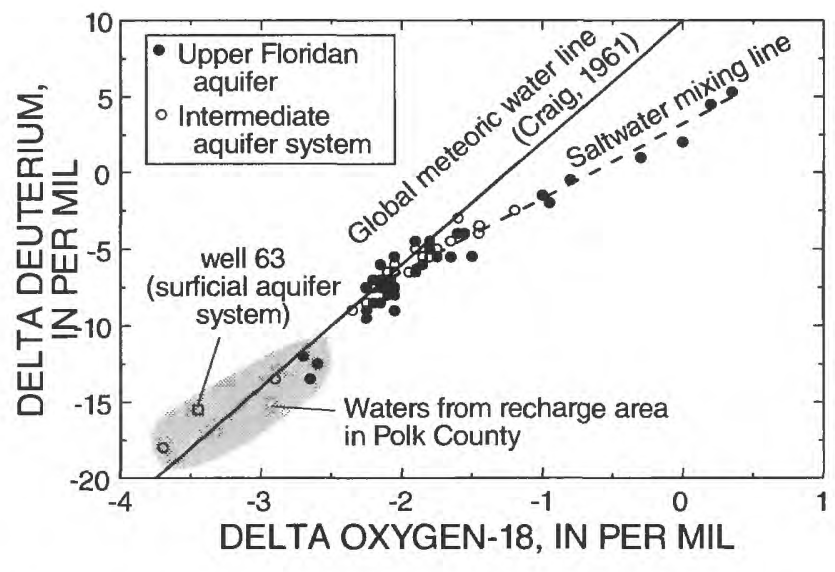

Figure 21. Relation between delta deuterium and delta oxygen-18 in water from the Upper Floridan aquifer and intermediate aquifer system.

with inland rainwater usually isotopically lighter than rainfall near the coast (Katz and others, 1995a; Swancar and Hutchinson, 1995; Meyers and others, 1993). Downgradient waters from the Upper Floridan aquifer were isotopically heavier than those in the recharge area $\left(\delta \mathrm{D}\right.$ around -7 per mil and $\delta^{18} \mathrm{O}$ around -2 per mil), but their values also plot near the global meteoric water line. Water in this part of the aquifer is "old" (probably greater than 10,000 years old; Plummer, 1977) and presumably recharged in the present-day recharge area of Polk County. Climatic conditions during recharge may have been different, resulting in waters with heavier $\delta \mathrm{D}$ and $\delta^{18} \mathrm{O}$.

The isotopically heaviest waters had chloride concentrations similar to seawater. Waters from the saltwater mixing zone (chloride greater than 250 $\mathrm{mg} / \mathrm{L}$ ) plot along a mixing line between the most saline water and the heavier downgradient water (rather than the upgradient recharge waters from Polk County) (figs. 21 and 22). This is an important consideration when using $\delta \mathrm{D}$ or $\delta^{18} \mathrm{O}$, rather than chloride, to compute fractions of saltwater mixing in geochemical models such as NETPATH. When upgradient ground water is used as the freshwater end member, the computed fraction of saltwater is significantly different if chloride is used as the conservative tracer compared to $\delta \mathrm{D}$ or $\delta^{18} \mathrm{O}$. In contrast, when freshwater from the downgradient part of the aquifer is used as the freshwater end member, more consistent results are computed using either chloride or $\delta \mathrm{D}$ or $\delta^{18} \mathrm{O}$ as the conservative tracer. (The saltwater end member remained the same for all calculations.)

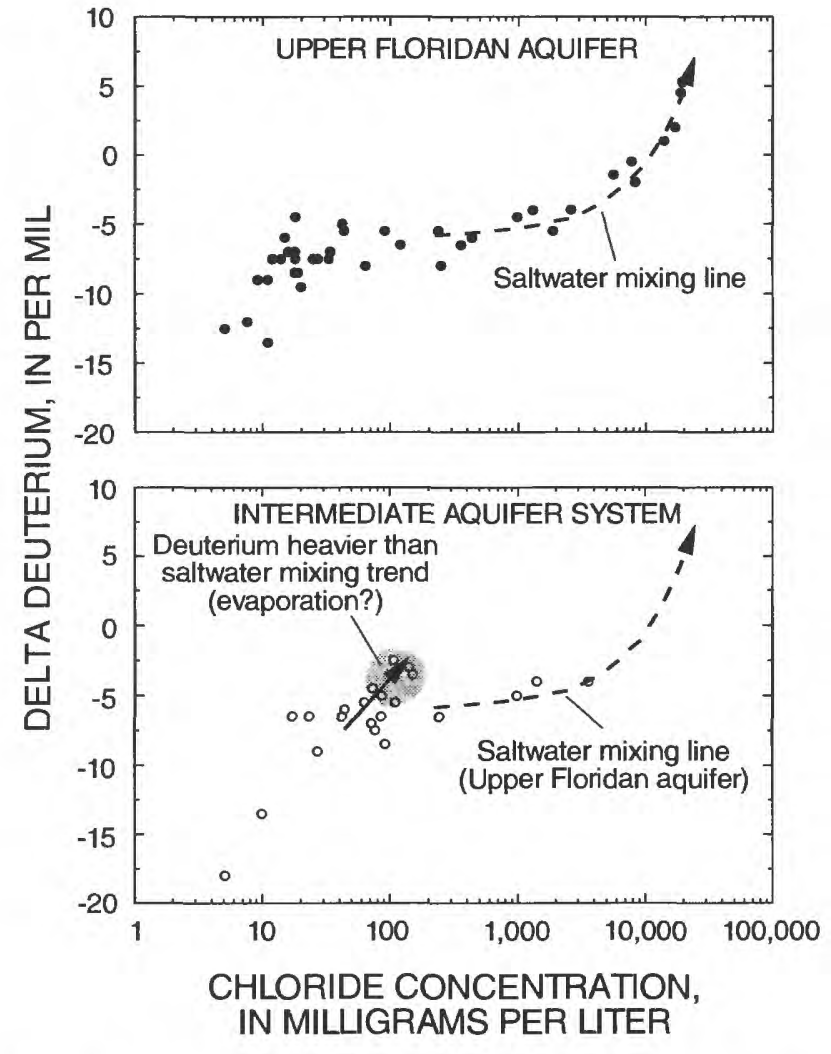

Figure 22. Relation between delta deuterium and chloride concentration in water from the Upper Floridan aquifer and intermediate aquifer system.

Waters from the intermediate aquifer system also were isotopically light in the recharge area and heavier downgradient (fig. 21). However, two trends are apparent when examining the relation between chloride concentration and $\delta \mathrm{D}$ or $\delta^{18} \mathrm{O}$ for the intermediate aquifer system (fig. 22). One trend follows the saltwater mixing line observed for the Upper Floridan aquifer. These intermediate aquifer system waters are in coastal areas, and isotopic data support that the saline water in both aquifers has a similar source.

The second trend is isotopically enriched waters at considerably lower chloride concentrations. These waters are from inland areas and correspond to waters that had elevated chloride concentrations compared to those in the Upper Floridan aquifer. The large increase in $\delta \mathrm{D}$ while chloride remains relatively low (less than 1 percent seawater) indicates that this is not residual seawater. A mineral source would not result in enrichment in $\delta \mathrm{D}$. Evaporation prior to recharge could cause isotopic enrichment with minor increases in chloride. Sites with enriched $\delta \mathrm{D}$ and $\delta^{18} \mathrm{O}$ are generally in low lying areas where standing water is 
common after heavy rains. As this ponded water evaporates, $\delta \mathrm{D}$ and $\delta^{18} \mathrm{O}$ fractionate at different rates resulting in heavier isotopes in solution and an offset from the global meteoric line. Evaporation also concentrates the amount of conservative ions in the water. This water eventually recharges the surficial aquifer system. Water from the surficial aquifer system in undeveloped inland Sarasota County has a wide range of chloride concentrations (chloride concentrations commonly exceed $50 \mathrm{mg} / \mathrm{L}$; Duerr and Wolansky, 1986). This water eventually recharges the intermediate aquifer system. Over long periods of time (probably on the order of 1,000's of years) this water presumably could result in elevated chloride concentrations and isotopically enriched waters in the intermediate aquifer system. However, this is undoubtedly a complex process because of the different permeable zones within the intermediate aquifer system and differences in the extent of interconnection between these permeable zones.

Water in the intermediate aquifer system that is characterized by high excess sulfate concentrations, indicative of upward leakage from the Upper Floridan aquifer, had relatively uniform $\delta \mathrm{D}$ and $\delta^{18} \mathrm{O}$ compositions ( $\delta \mathrm{D}$ values between -6.0 and -6.5 per mil for $\delta^{18} \mathrm{O}$ values between -1.9 and -2.1 per mil). These values are similar to downgradient freshwaters from the Upper Floridan aquifer, which further supports upward leakage from the Upper Floridan aquifer.

\section{Carbon-13}

Processes affecting the stable carbon isotope composition $\left(\delta^{13} \mathrm{C}\right)$ of inorganic carbon in ground water include carbonate mineral dissolution and precipitation, microbially mediated processes that oxidize organic carbon and generate $\mathrm{CO}_{2}$, and mixing of waters. In the Upper Floridan aquifer, $\delta^{13} \mathrm{C}$ was lightest in the recharge area (less than -8 per mil) and heaviest in discharge areas of coastal Sarasota County and the lower Peace River Basin (greater than -5 per mil). Carbon-13 values usually increased with depth in the Upper Floridan aquifer. The heavier $\delta^{13} \mathrm{C}$ values indicate dissolution of dolomite (mean $\delta^{13} \mathrm{C}$ of dolomite measured for this study was 1.7 per mil; table 2), which is more common deeper in the aquifer. In discharge areas, this isotopically heavy carbon moves upward to shallower parts of the aquifer. The influence of dolomite dissolution is illustrated by an increase in magnesium over that expected for saltwater mixing and an accompanied enrichment in $\delta^{13} \mathrm{C}$ (dedolomitization trend in fig. 23). Calcite precipitation, which is a reaction that accompanies dolomite dissolution, removes some of the isotopically heavy carbon from solution and probably accounts for why the $\delta^{13} \mathrm{C}$ values in ground water are isotopically lighter than those of dolomite.

The opposite relation is seen for the most saline waters from the Upper Floridan aquifer (chloride concentrations greater than about $5,000 \mathrm{mg} / \mathrm{L}$ or about 25 percent seawater). For these waters magnesium was depleted relative to conservative saltwater mixing. As magnesium becomes more depleted, $\delta^{13} \mathrm{C}$ values tend to become isotopically lighter (fig. 23). This is consistent with dolomitization removing isotopically heavy carbon, resulting in isotopically lighter carbon in solution.

In water from the intermediate aquifer system, $\delta^{13} \mathrm{C}$ values in ground water typically were lighter compared to $\delta^{13} \mathrm{C}$ values in the Upper Floridan aquifer (less than -8 per mil for most of the study area). Values of $\delta^{13} \mathrm{C}$ increase toward the coast and within the Peace River Basin, which corresponds to areas of

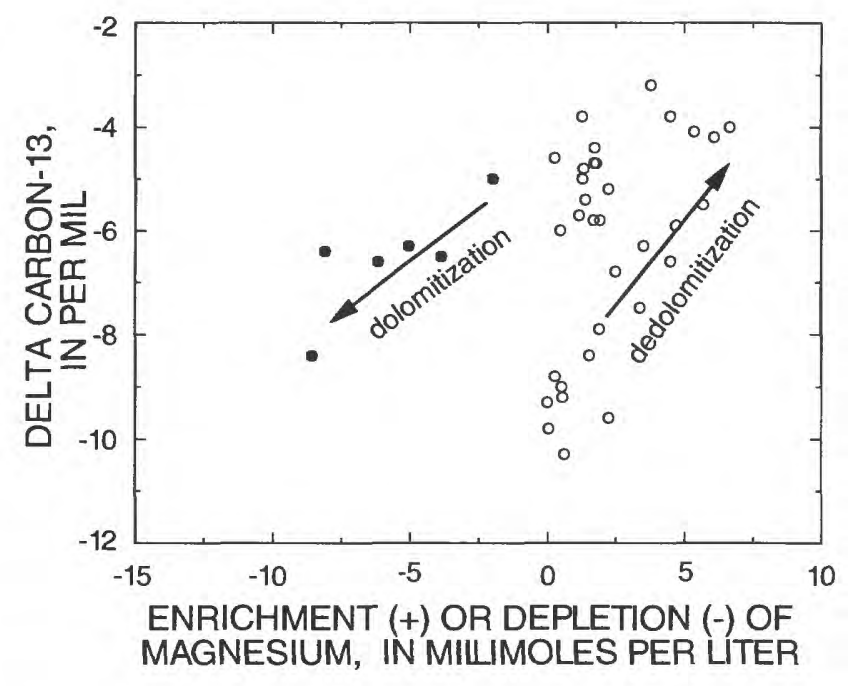

(Enrichment or depletion relative to conservative mixing between modem seawater and upgradient ground water from well 62.)

\section{EXPLANATION}

- Chloride concentration greater than 250 and less than 5,000 milligrams per liter

- Chloride concentration greater than 5,000 milligrams per liter

Figure 23. Relation between delta carbon-13 and enrichment or depletion of magnesium relative to conservative saltwater mixing in water from the Upper Floridan aquifer. 
upward leakage from the Upper Floridan aquifer to the intermediate aquifer system.

Inland waters from the intermediate aquifer system that had slightly elevated chloride concentrations and isotopically enriched $\delta \mathrm{D}$ and $\delta^{18} \mathrm{O}$ values usually had isotopically light $\delta^{13} \mathrm{C}$ values. These waters also had elevated bicarbonate concentrations, which apparently is from more extensive dissolution of calcite and dolomite. The lighter $\delta^{13} \mathrm{C}$ values indicate reactions with an isotopically light carbon source such as meteoric $\mathrm{CO}_{2}$ or organic matter (with $\delta^{13} \mathrm{C}$ values typically around -25 per mil; Rightmire and Hanshaw, 1973; Buchardt and Fritz, 1980). The oxidation of organic matter generates isotopically light $\mathrm{CO}_{2}$, which could further drive the dissolution of carbonate minerals (equations 11 and 12). In addition, the $\delta^{13} \mathrm{C}$ of carbonate minerals from the intermediate aquifer system may be somewhat lighter than the dolomites from the Upper Floridan aquifer, resulting in isotopically lighter ground water. (The mean $\delta^{13} \mathrm{C}$ of calcite from the intermediate aquifer system measured for this study was -2.2 per mil.)

\section{Sulfur-34}

Sulfate originating from atmospheric precipitation, marine sulfur (from gypsum dissolution or seawater), and pyrite oxidation all have distinctly different sulfur isotope signatures. Sources of sulfate and sulfide in the ground water can be evaluated by examining the sulfur isotope composition of both sulfur species (sulfate and sulfide; $\delta^{34} \mathrm{~S}_{\text {sulfate }}$ and $\delta^{34} \mathrm{~S}_{\text {sulfide }}$ ). Microbially mediated sulfate reduction transforms sulfate to reduced sulfur (sulfide). The bacteria responsible for these reactions fractionate the sulfur by preferentially using isotopically light sulfur (sulfur-32), causing the remaining sulfate to become isotopically enriched in sulfur-34. Sulfur isotopes can be used to evaluate the extent of sulfate reduction and precipitation of sulfide minerals.

\section{Sulfate}

In water sampled from the Upper Floridan aquifer, $\delta^{34} \mathrm{~S}_{\text {sulfate }}$ ranged from 13.8 to 44.2 per mil

(fig 24). In the recharge area, where sulfate concentrations are low, $\delta^{34} S_{\text {sulfate }}$ values were considerably more variable than downgradient in the aquifer. The sulfur isotope composition of rainwater was not analyzed for this study; however, $\delta^{34} \mathrm{~S}_{\text {sulfate }}$ in rainwater from north-central Florida ranged from 3.4 to 5.9 per
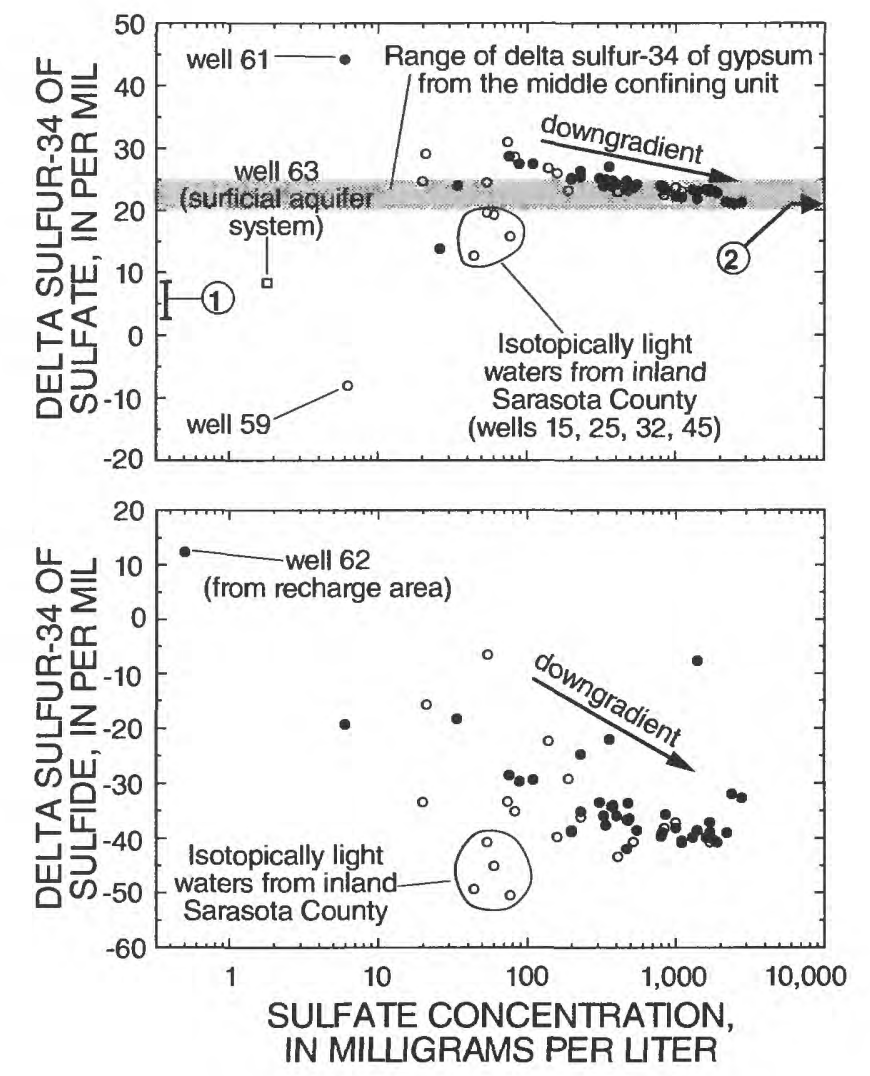
EXPLANATION
- Upper Floridan aquifer
- Intermediate aquifer system
(1) Typical range of delta sulfur-34 in rainwater
(2) Delta sulfur-34 of modem seawater

Figure 24. Relation between delta sulfur-34 of sulfate and sulfate concentration, and delta sulfur-34 of sulfide and sulfate concentration in water from the Upper Floridan aquifer and intermediate aquifer system.

mil (Katz and others, 1995b). This is similar to ranges reported by Östlund (1959) and Jensen and Nakai (1961) for $\delta^{34} \mathrm{~S}_{\text {sulfate }}$ in rainwater in unindustrialized regions (between 3.2 and 8.2 per mil). A water sample from the surficial aquifer system in Polk County had a $\delta^{34} S_{\text {sulfate }}$ value of 8.3 per mil (well 63), which should be representative of recent recharge. The greater range of $\delta^{34} \mathrm{~S}_{\text {sulfate }}$ in Upper Floridan aquifer waters from the recharge area is undoubtedly due to differences in the extent of reactions influencing sulfate. Oxidation of reduced sulfur, in the form of organic sulfur or a sulfide mineral such as pyrite, can add lighter sulfate to solution. Biological uptake and microbial sulfate reduction fractionate sulfur isotopes, resulting in isotopically heavier sulfate. When sulfate concentrations are low, a greater fraction of the total 
sulfur is usually reduced to sulfide, and the remaining sulfate in solution becomes isotopically heavy. Adsorption of sulfate onto soils and clays also may fractionate some of the sulfur (Krouse, 1980). Water from upgradient well 61 had the heaviest $\delta^{34} S_{\text {sulfate }}$ value of 44.2 per mil, indicating that a significant amount of sulfate was reduced. However, some of the reduced sulfur may have been removed from solution because the sulfide concentration was relatively low (0.37 mg/L).

For Upper Floridan aquifer waters with higher sulfate concentrations (typically greater than 250 $\mathrm{mg} / \mathrm{L}), \delta^{34} \mathrm{~S}_{\text {sulfate }}$ values were less variable and often were between 21 and 25 per mil (fig. 24). These values are within the range of $\delta^{34} \mathrm{~S}$ of gypsum in the middle confining unit and modern seawater. This is consistent with geochemical evidence that gypsum dissolution and saltwater mixing are the dominant sources of sulfate in these downgradient waters.

In the intermediate aquifer system, $\delta^{34} \mathrm{~S}_{\text {sulfate }}$ ranged from -8.0 to 31.0 per mil (fig. 24). The lightest value is from the most upgradient ground water (well 59). This indicates an isotopically light sulfur source, such as pyrite or sulfur-rich organic matter. Waters from the intermediate aquifer system in inland Sarasota County (wells 15, 25, 32, and 45) had $\delta^{34} S_{\text {sulfate }}$ values that were lighter than marine sulfate (less than 20 per mil). These waters also had relatively low (less than $100 \mathrm{mg} / \mathrm{L}$ ) sulfate concentrations, although the concentrations were considerably higher than in rainwater and in water from the surficial aquifer system (National Acid Deposition Program/National Trends Network, 1994; Duerr and Wolansky, 1986; Southwest Florida Water Management District, 1991). Thus, meteoric water is not a likely source of significant concentrations of sulfate. Iron also is elevated for these same intermediate aquifer system waters (greater than $30 \mu \mathrm{g} / \mathrm{L}$ ), which implies that some of the sulfur could be from isotopically light pyrite. Pyrite has been observed in the Hawthorn Group and surficial deposits in the study area, although sufficient quantities of fresh (unoxidized) sample could not be obtained for $\delta^{34} \mathrm{~S}$ analysis. Pyrite oxidation would have to occur in the shallow part of the ground-water system, as waters from the intermediate aquifer system were all supersaturated with respect to pyrite.

Water from the intermediate aquifer system with high sulfate concentrations had $\delta^{34} \mathrm{~S}_{\text {sulfate }}$ values within the range of gypsum and seawater (fig. 24).
These waters usually are at the end of flow paths in areas of upward leakage from the Upper Floridan aquifer. The sulfur isotope composition of these waters is indistinguishable from water from the Upper Floridan aquifer, indicating the same source of sulfate for both aquifers.

Waters from both the intermediate aquifer system and Upper Floridan aquifer that had $\delta^{34} \mathrm{~S}_{\text {sulfate }}$ values in the range of marine sulfate ( 21 to 25 per mil) have sulfate from both seawater and sulfate mineral dissolution. These marine sources can be distinguished by their $\delta^{34} S_{\text {sulfate }}$ values. High sulfate, low chloride waters represent freshwater that dissolved gypsum. These freshwaters had $\delta^{34} \mathrm{~S}_{\text {sulfate }}$ values between 23 and 25 per mil, which is isotopically heavier than the saline waters (fig. 25). This is within the range of evaporites from middle confining unit of the Avon Park Formation (average $\delta^{34} S$ of 23.4 per mil). In contrast, gypsum from the Lower Floridan aquifer and the lower confining unit (Oldsmar and Cedar Keys Formations) had isotopically lighter $\delta^{34} \mathrm{~S}$ values, with an average value of 20.1 per mil. This supports the hypothesis that the gypsum causing the high sulfate waters in the Upper Floridan aquifer is from the base of the Upper Floridan aquifer or the middle confining unit, rather than from the Lower Floridan aquifer or the lower confining unit.

As chloride concentrations (or fraction of seawater) increase, $\delta^{34} \mathrm{~S}_{\text {sulfate }}$ values become progres-

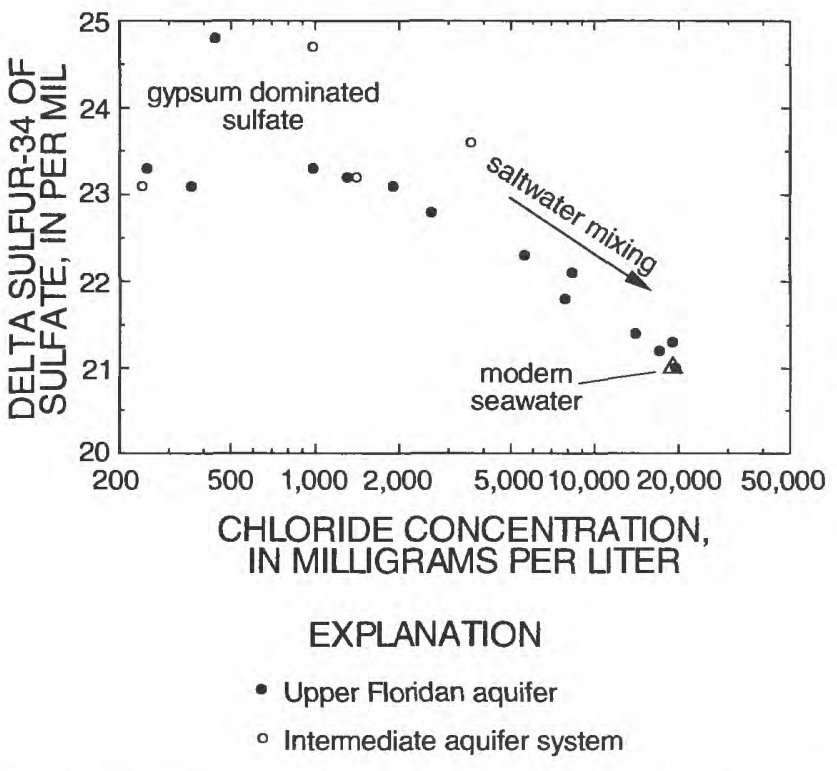

Figure 25. Relation between delta sulfur-34 of total sulfer and chloride concentration in water from the Upper Floridan aquifer and intermediate aquifer system with chloride concentration greater than $200 \mathrm{mg} / \mathrm{L}$. 
sively lighter to about 21 per mil (fig. 25). This indicates that the saltwater end-member water has a $\delta^{34} S_{\text {sulfate }}$ value of about 21 per mil, which is similar to that of modern seawater (Rees and others, 1978). However, the seawater is not necessarily modern because the $\delta^{34} \mathrm{~S}_{\text {sulfate }}$ of seawater has varied little (probably within 0.5 per mil) since the middle Miocene (15 million years ago) (Claypool and others, 1980).

The saline water in the Upper Floridan aquifer apparently has a relatively shallow seawater source, rather than from water circulating deeply through the Lower Floridan aquifer, as hypothesized by Kohout and others (1977). To move to the Upper Floridan aquifer from the Lower Floridan aquifer, saline water would have to move through gypsiferous beds of the middle confining unit. Because gypsum is so soluble, particularly in seawater, the influence of gypsum dissolution should be apparent. For example, excess sulfate concentrations should be much higher and $\delta^{34} S_{\text {sulfate }}$ values should reflect a mixture between seawater and gypsum sources, which clearly is not the case. Saline water in this part of the aquifer has not dissolved significant amounts of gypsum. In contrast, the composition of water in the downgradient part of the freshwater flow system is dominated by gypsum dissolution.

\section{Sulfide}

The $\delta^{34} \mathrm{~S}$ composition of sulfide is controlled by isotopic exchange with a large, but variable, amount of sulfate in the water, and by the extent of sulfate reduction (Rye and others, 1981). In both the Upper Floridan aquifer and the intermediate aquifer system, sulfate concentrations were always significantly higher than sulfide concentrations. Values of $\delta^{34} \mathrm{~S}_{\text {sulfide }}$ ranged from -42.0 to 12.4 per mil in the Upper Floridan aquifer and from -50.5 to -6.5 per mil in the intermediate aquifer system (fig. 24).

The heaviest $\delta^{34} \mathrm{~S}_{\text {sulfide }}$ value (12.4 per mil) was from water from the most upgradient, shallow Upper Floridan aquifer well. The sulfate concentration was very low in this water $(0.5 \mathrm{mg} / \mathrm{L})$ and is lower than the concentration in the overlying surficial aquifer system $(1.8 \mathrm{mg} / \mathrm{L})$. Insufficient sulfate was collected for $\delta^{34} S_{\text {sulfate }}$ analysis, and so the extent of sulfate reduction could not be ascertained. However, the $\delta^{34} \mathrm{~S}_{\text {sulfide }}$ value is similar to $\delta^{34} \mathrm{~S}_{\text {sulfate }}$ in the recharge area (for example well 64), indicating that much of the sulfate may have been reduced to sulfide. If this was the case, the majority of sulfide has been removed from the water (probably by precipitation of a sulfide mineral) because the sulfate concentration is much greater than the sulfide concentration (in $\mathrm{mmol} / \mathrm{L}$ ). (Anoxic conditions in the ground water are conducive to pyrite precipitation.) Positive $\delta^{34} S_{\text {sulfide }}$ values also have been observed in other sulfide-bearing waters in recharge areas of the Upper Floridan aquifer (Rye and others, 1981; Sacks, 1996).

Values of $\delta^{34} \mathrm{~S}_{\text {sulfide }}$ become increasingly lighter in a downgradient direction in the Upper Floridan aquifer and are lightest in coastal areas at the end of flow paths and in the Peace River valley, where sulfate concentrations are high (fig. 24 and fig. 9a). Lighter $\delta^{34} \mathrm{~S}_{\text {sulfide }}$ values probably indicate both longer residence times in the aquifer and an isotopically lighter pool of sulfate that is reduced (with values near marine sulfate).

In the intermediate aquifer system, a consistent trend in a downgradient direction was not observed. The lightest $\delta^{34} \mathrm{~S}_{\text {sulfide }}$ values (less than -45 per mil) were from inland Sarasota County, where light $\delta^{34} \mathrm{~S}_{\text {sulfate }}$ values were also noted (fig. 24). The lighter values are undoubtedly related to fractionation of the isotopically light sulfate (less than 20 per mil). Isotopically heavy values (greater than -20 per mil) were in water from several wells east of the Peace River. One of these waters (well 40 ), had isotopically light $\delta \mathrm{D}$ and $\delta^{18} \mathrm{O}$ values similar to upgradient water from the recharge area in Polk County, and is probably indicative of recent recharge, with a relatively short residence time in the aquifer.

The difference between the $\delta^{34} \mathrm{~S}$ values of sulfate and sulfide $\left(\Delta^{34} S\right)$ is called the fractionation factor (Rye and others, 1981). Most of the $\Delta^{34} S$ values were around 60 per mil; see appendix). This is near the value expected for fractionation at isotopic equilibrium between sulfate and sulfide and indicates slow sulfate reduction in waters with long residence times in the aquifer (Rye and others, 1981). Lesser $\Delta^{34} S$ values may indicate that sulfate reduction took place at a considerably faster rate (Rye and others, 1981). In the Upper Floridan aquifer, the greatest $\Delta^{34} S$ values were in central to coastal Sarasota County and within lower Peace River valley, representing waters with long flow paths and long aquifer residence times. Water from the intermediate aquifer system sometimes had greater $\Delta^{34} S$ values than water from the Upper Floridan aquifer. The reason for this is unclear, particularly because water from the Upper Floridan aquifer 
is expected to have a longer residence time than water from the intermediate aquifer system, which can receive recharge from the overlying surficial aquifer system in much of the study area. However, there is a lack of understanding of continuity and interconnection of permeability units in the intermediate aquifer system, and some parts of the aquifer system probably do not receive modern recharge.

\section{Strontium-87/Strontium-86}

Strontium isotopes can be used to evaluate the source of dissolved strontium in the water. Because areas of high strontium concentrations are often associated with high sulfate concentrations, this may also be useful in understanding sources of sulfate. The ratio strontium-87 to strontium- $86\left({ }^{87} \mathrm{Sr} /{ }^{86} \mathrm{Sr}\right)$ has varied significantly in seawater over geologic time (DePaolo and Ingram, 1985; Elderfield, 1986; Hess and others, 1986). This change in ${ }^{87} \mathrm{Sr} /{ }^{86} \mathrm{Sr}$ is particularly distinct between the Eocene and the Miocene epochs, which encompasses the age of rocks in the middle confining unit (middle Eocene age), the Upper Floridan aquifer (middle Eocene to Oligocene age), and the intermediate aquifer system (usually Miocene age). Because aquifer rocks are marine in origin, strontium in the rock is presumed to originate from seawater during the time of deposition. Gypsum and calcite retain the seawater ${ }^{87} \mathrm{Sr} /{ }^{86} \mathrm{Sr}$ ratio from the time of deposition (fig. 6). Dolomite, however, often has a different ${ }^{87} \mathrm{Sr} /{ }^{86} \mathrm{Sr}$ ratio because of diagenetic changes during dolomitization. Strontium isotope ratios were analyzed for waters along flow path 2 (fig. 5b; fig. 11). In addition, two deep saline ground waters with chemical compositions similar to modern seawater (wells 2 and 23) were analyzed for ${ }^{87} \mathrm{Sr} /{ }^{86} \mathrm{Sr}$; several other ground waters were analyzed for ${ }^{87} \mathrm{Sr} /{ }^{86} \mathrm{Sr}$ to establish expected ranges of strontium isotope ratios and to complement a project in the City of Sarasota (Broska and Knochenmus, 1996).

Most waters from the Upper Floridan aquifer had ${ }^{87} \mathrm{Sr} /{ }^{86} \mathrm{Sr}$ ratios in the range of Eocene seawater (fig. 26). The source of strontium along flow path 2 initially appears to be celestite (based on concurrent increases in strontium and sulfate concentrations). Further along the flow path, where sulfate concentrations are high (greater than $500 \mathrm{mg} / \mathrm{L}$ ) and the waters are near equilibrium with respect to celestite, the dominant source of strontium apparently is trace concentrations in gypsum. The relatively constant ${ }^{87} \mathrm{Sr} /{ }^{86} \mathrm{Sr}$ ratio of waters from the Upper Floridan aquifer

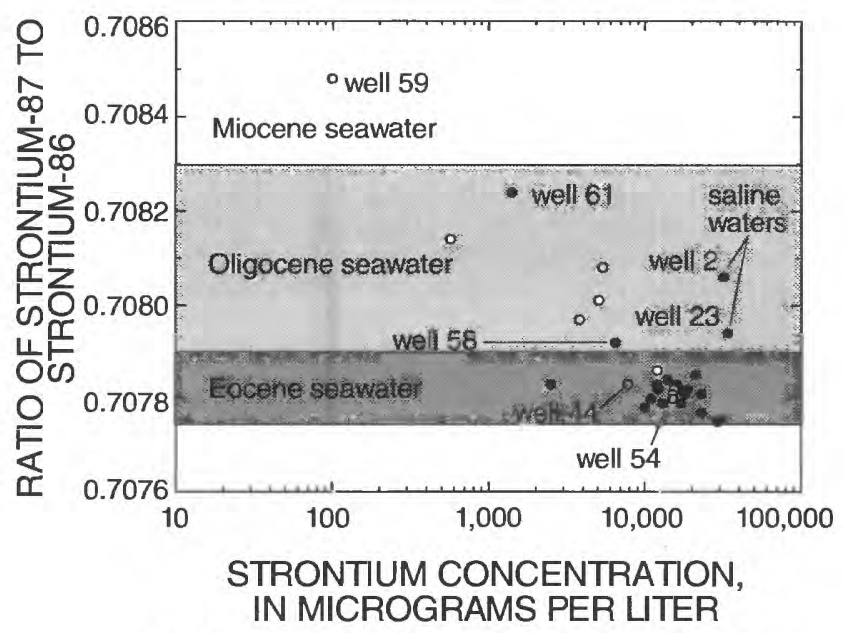

Most rocks in intermediate aquifer system deposited from seawater of Miocene age

Rocks in shallow part of Upper Floridan aquifer deposited from seawater of Oligocene age

Rocks in middle to lower part of Upper Floridan aquifer and in the middle confining unit deposited from seawater of Eocene age

\section{EXPLANATION \\ - Upper Floridan aquifer \\ - Intermediate aquifer system}

Figure 26. Relation between the ratio of strontium- 87 to strontium-86 and strontium concentration in water from the Upper Floridan aquifer and intermediate aquifer system, plotted with the range of strontium- 87 to strontium- 86 in seawater from the Miocene, Oligocene, and Eocene epochs.

indicates that the strontium from both celestite and gypsum was originally deposited in Eocene age seawater.

Several waters from the recharge area (wells 58 and 61) and the two saline waters with chemical compositions similar to seawater (wells 2 and 23) had ${ }^{87} \mathrm{Sr} /{ }^{86} \mathrm{Sr}$ ratios in the range of Oligocene seawater.

The upgradient waters probably represent a mixture of strontium from the overlying intermediate aquifer system (Miocene age rock and seawater signature), Oligocene and Eocene age limestones in the aquifer, and dolomite in the aquifer (which can have a Miocene age seawater signature; table 2). The saline waters with ${ }^{87} \mathrm{Sr} /{ }^{86} \mathrm{Sr}$ ratios in the range of Oligocene seawater are from rocks of Eocene age. The Oligocene age seawater signature for these waters is from a mixture of strontium in the aquifer rock (with an Eocene age seawater signature) and from younger seawater introduced into the aquifer. 
In the intermediate aquifer system, the ${ }^{87} \mathrm{Sr} /{ }^{86} \mathrm{Sr}$ ratio was in the range of Miocene seawater ratios in the most upgradient water (well 59) and decreased toward Eocene age seawater ratios in water from deeper parts of the aquifer system near the coast (fig. 26). $\mathrm{The}^{87} \mathrm{Sr} /{ }^{86} \mathrm{Sr}$ ratio in the range of Miocene seawater is consistent with the age of the aquifer host rock. Downgradient near the coast, water from the lower permeable zone had ${ }^{87} \mathrm{Sr} /{ }^{86} \mathrm{Sr}$ ratios in the range of Eocene seawater and had very high sulfate and strontium concentrations (greater than $1,000 \mathrm{mg} / \mathrm{L}$ and $10,000 \mu \mathrm{g} / \mathrm{L}$, respectively). These high concentrations, along with other chemical and isotopic evidence, indicate that the waters are strongly influenced by upward leakage from the Upper Floridan aquifer, with sulfate originating from dissolution of gypsum in the deeper part of the aquifer within the freshwater flow system. Strontium isotope data support Eocene age gypsum as the source for strontium (and the associated sulfate). Discharging conditions at the coast transport this high sulfate water from deep in the Upper Floridan aquifer to the overlying intermediate aquifer system near the coast.

Water from the upper permeable zone of the intermediate aquifer system in coastal Sarasota County had ${ }^{87} \mathrm{Sr} /{ }^{86} \mathrm{Sr}$ ratios in the range of ratios for Oligocene seawater. These waters probably represent a mixture of strontium from the Miocene age host rock and from Eocene age gypsum from the underlying Upper Floridan aquifer (upwelling waters). The ${ }^{87} \mathrm{Sr} /{ }^{86} \mathrm{Sr}$ ratio at the end of flow path 2 increased between the last two wells in the upper permeable zone. Strontium in the downgradient water may be influenced by exchange with clays, resulting in a greater ${ }^{87} \mathrm{Sr} /{ }^{86} \mathrm{Sr}$ ratio in the downgradient water. However, further work needs to be done to establish the interconnection between permeable zones and to quantify reactions occurring in this heterogeneous aquifer system.

Several inland intermediate aquifer system waters (wells 44 and 54) with relatively low sulfate concentrations (less than $100 \mathrm{mg} / \mathrm{L}$ ) and elevated strontium concentrations (greater than $5,000 \mu \mathrm{g} / \mathrm{L}$ ) had ${ }^{87} \mathrm{Sr} /{ }^{86} \mathrm{Sr}$ ratios in the range of ratios for Eocene seawater. The relatively high strontium-to-sulfate ratio indicates that localized celestite dissolution, rather than gypsum dissolution, is the source of strontium in this water. The Eocene age seawater signature for ${ }^{87} \mathrm{Sr} /{ }^{86} \mathrm{Sr}$ indicates a complex history for the celes- tite, which may include an Upper Floridan aquifer (Eocene age) source for the original strontium.

In summary, strontium isotope data can be used in conjunction with other geologic, hydrologic, and chemical data to provide evidence to the source of strontium in the ground water. Data from this study indicate that Eocene age gypsum is the source of strontium (and associated sulfate) in areas where sulfate concentrations are high in the intermediate aquifer system. However, interpretation of strontium isotope data can be complicated by multiple strontium sources, reactions with dolomite, which underwent diagenesis, and complex flow paths. Thus, strontium isotope data need to be interpreted with caution and are not always conclusive in complex carbonate aquifer systems.

\section{GEOCHEMICAL MODELING}

Chemical and isotopic data indicate that dedolomitization reactions control the chemical composition of water in the Upper Floridan aquifer along flow paths. Geochemical mass-transfer modeling can help quantify these reactions, and isotopic data can be used to support the uniqueness of these reactions. Reactions occurring in the shallowest part of the aquifer were modeled between wells along the three flow paths. By considering models for the shallow part of the aquifer (wherever possible), locations along flow paths where significant amounts of mass transfer occur can be evaluated in light of hydrologic conditions, such as upwelling from deeper parts of the aquifer. Upwelling of deep ground water was further evaluated to determine whether increases in sulfate can be attributed to mixing with deep ground water, rather than reactions in the shallow part of the aquifer.

The study area has been the focus of several geochemical modeling studies. Much of the background of the modeling approach used here has its foundations in work done by Plummer (1977) and Plummer and others (1983) in a classic study of geochemical reactions in the Upper Floridan aquifer. These studies modeled mass transfer along a flow path from the high in the potentiometric surface in Polk County through the central Peace River Basin before the saltwater mixing zone. Dedolomitization reactions (gypsum and dolomite dissolution and calcite precipitation) were the dominant reactions controlling the chemical evolution of water in that part of the Upper Floridan aquifer. These studies relied on samples from wells with large 
open-hole intervals, however, and no distinction was made with respect to vertical variability of groundwater chemistry or mineralogical changes with depth in the aquifer. Knowledge of such chemical and mineralogical changes with depth could help identify where important reactions occur in the aquifer.

Jones and others (1993), who linked a groundwater flow model to a simplified mass-transfer model (which considered calcium, magnesium, and sulfate), determined that areas where unrealistically high amounts of mass transfer (dedolomitization reactions) were predicted correspond to regions of upward flow in the aquifer. They suggested that ground water in these areas carries a historical signature of geochemical reactions that occurred deeper within the aquifer or below the base of the aquifer. In a follow-up geochemical modeling study, Johnson (1994) concluded that mass transfer could be minimized by considering upwelling of ground water (using a hypothetical chemical composition), which is more consistent with petrographic observations by Budd and others (1993) that calcite is not precipitating in the shallow part of the aquifer. Johnson (1994), who did not have sulfur isotope data to evaluate sulfur sources, hypothesized that organic sulfur, rather than gypsum, was the source of high sulfate near the coast in Sarasota County. Sacks and others (1995) evaluated shallow and deeply circulating flow paths in the Upper Floridan aquifer in Sarasota County. Deeply circulating flow paths, which dissolved gypsum near the base of the aquifer, were found to control the chemical evolution of ground water. This water subsequently moved upward to shallow parts of the aquifer upgradient of the saltwater mixing zone, resulting in high sulfate concentrations in deep and shallow parts of aquifer.

\section{Model Description}

The model NETPATH (Plummer and others, 1991 ; 1994) computes a set of reactions (including mineral dissolution or precipitation, ion exchange, and gas exchange) based on the net mass transfer of elements between initial and final waters, given a set of constraints (elemental, isotopic, electron balance). The model also can compute an isotopic composition for the final water, given the isotopic composition of the initial water, isotopic composition of dissolving phases, and fractionation factors of precipitating phases. Although the resulting models are not unique and cannot be validated, certain models can be rejected based on violations of thermodynamics (for example, dissolution of a mineral from a supersaturated water) or large discrepancies between observed and computed $\delta^{13} \mathrm{C}$ and $\delta^{34} \mathrm{~S}$ values of the final water. For flow paths 1 and 2, observed and computed ${ }^{87} \mathrm{Sr} /{ }^{86} \mathrm{Sr}$ ratios also were compared. Descriptions of the mass-balance modeling approach, including relevant equations, are presented in detail elsewhere (Plummer, 1977; Plummer and Back, 1980; Plummer and others, 1983; Plummer and others, 1990; Busby and others, 1991).

The models were constrained by sulfur, calcium, magnesium, carbon, iron, strontium, and electron balance (redox state). Electron balance was necessary for modeling redox reactions such as oxidation of organic matter. Chloride was added to the models to determine mixing ratios when saltwater mixing was considered (when chloride concentration was greater than or equal to $250 \mathrm{mg} / \mathrm{L}$ in the final water; water from well 2 was used as the saltwater end member). Reaction phases included in the models were gypsum, stoichiometric dolomite and calcite, celestite, organic matter (represented as $\mathrm{CH}_{2} \mathrm{O}$ ), $\mathrm{CO}_{2}$ gas, pyrite $\left(\mathrm{FeS}_{2}\right)$, and goethite $(\mathrm{FeOOH})$. Pyrite precipitation was included as a sink for sulfur, which also allows for the fractionation of $\delta^{34} \mathrm{~S}$ during sulfate reduction. Dissolved organic carbon was present in most ground-water samples in concentrations greater than $1.0 \mathrm{mg} / \mathrm{L}$; this could provide the source of organic matter for sulfate reduction. Goethite was included in models to provide a mineral source for iron, which was necessary when pyrite precipitation was calculated. The choice of carbon phases $\left(\mathrm{CO}_{2}\right.$ gas and $\left.\mathrm{CH}_{2} \mathrm{O}\right)$ was based on previous mass-balance modeling of the Upper Floridan aquifer (Plummer, 1977; Plummer and others, 1983). For models including saltwater mixing, $\mathrm{Ca} / \mathrm{Na}$ ion exchange was also considered, which can occur when sodium-rich saltwater encounters calcium-rich ground water. Trace amounts of clay minerals in the aquifer could serve as ion-exchange sites.

Reactions were modeled along three flow paths in the Upper Floridan aquifer, illustrated in figures $5 \mathrm{~b}$, 7 and 11. The flow paths were broken into sections and reactions were modeled between the shallowest wells in each section. Water at the upgradient well in a section was considered the initial water and water at the downgradient well was considered the final water. The chemical evolution of water along the flow paths is characterized by increases in calcium, magnesium, and sulfate (figs. 11 and 15). In the downgradient part of all flow paths, sodium and chloride concentrations increase because of saltwater mixing. 
Several models often were computed for a given section of a flow path. Major reactions were usually very similar, but the models often varied by differences in minor amounts of mass transfer of pyrite, goethite, $\mathrm{CO}_{2}$, and $\mathrm{CH}_{2} \mathrm{O}$. Differences in minor reactions influenced the calculated $\delta^{13} \mathrm{C}$ and $\delta^{34} \mathrm{~S}$ values of the final water. Models with pyrite precipitation were considered over those with goethite precipitation because goethite is undersaturated in most ground waters (see appendix). When several models were computed, the model with the least amount of pyrite precipitation usually had $\delta^{34} \mathrm{~S}$ values closest to observed values. Models with $\mathrm{CO}_{2}$ ingassing were considered to be unrealistic in the aquifer discharge area. Plummer and others (1983) concluded that $\mathrm{CO}_{2}$ enters the aquifer along part of a flow path between Polk and Hardee Counties, in the recharge area, which they suggest may be from soil-zone $\mathrm{CO}_{2}$. However, the exact mechanism of carbon exchange $\left(\mathrm{CO}_{2}\right.$ ingassing, fermentation, microbial respiration) was not resolved, and is beyond the scope of the present study.
Minor charge imbalances also can influence the mass transfer of neutral compounds like $\mathrm{CH}_{2} \mathrm{O}$ or $\mathrm{CO}_{2}$ (Plummer and others, 1994, p. 15).

\section{Shallow Upper Floridan Aquifer Models}

Major reactions modeled for all three flow paths were gypsum dissolution, dolomite dissolution, and calcite precipitation (dedolomitization reactions) (table 6; fig. 27). This is consistent with results from other geochemical modeling studies of the aquifer (Plummer, 1977; Plummer and others; 1983; Sprinkle, 1989; Jones and others, 1993; Johnson, 1994; Sacks and others, 1995). For flow path 1, which is the shortest path, the magnitude of dedolomitization reactions was similar for both sections of the path. The first section is within a transition between aquifer recharge and discharge conditions (based on predevelopment conditions; Ryder, 1985), and the last section is in the discharge area. For flow path 2, the

Table 6. NETPATH models between the shallowest Upper Floridan aquifer waters along the three flow paths

[Units in millimoles per liter (mmol/L) unless otherwise noted; positive mass transfer indicates dissolution or ingassing; negative mass transfer indicates precipitation or outgassing; cal, calcite; dol, dolomite; gyp, gypsum; $\delta^{34} \mathrm{~S}$, delta sulfur-34; $\delta^{13} \mathrm{C}$, delta carbon-13; calc, calculated; obs, observed; --, not modeled; isotope data used in models unless otherwise specified: $\delta^{13} \mathrm{C}_{\text {of }} \mathrm{CH}_{2} \mathrm{O}$ and $\mathrm{CO}_{2}=-25.0$ per mil; $\delta^{13} \mathrm{C}$ of calcite $=0$ per mil (when dissolving); $\delta^{34} \mathrm{~S}$ of celestite $=26.0$ per mil (when dissolving); ${ }^{87} \mathrm{Sr} /{ }^{86} \mathrm{Sr}$ of celestite $=0.7078$; for precipitating phases, $\delta^{13} \mathrm{C}$ or $\delta^{34} \mathrm{~S}$ computed by model based on Rayleigh calculations and fractionation factors defined at the midpoint $(\mathrm{X}=0.5)$ between initial and final water compositions; $\delta^{13} \mathrm{C}$ (observed) based on DOC of -25.0 per mil: $\delta^{34} \mathrm{~S}$ (observed) based on measured $\delta^{34} \mathrm{~S}$ of sulfate and sulfide; all models have less than $0.10 \mathrm{mmol} / \mathrm{L}$ goethite dissolution, except for 2-d $(0.16 \mathrm{mmol} / \mathrm{L})$ and $3-\mathrm{d}(2.05 \mathrm{mmol} / \mathrm{L})$, less than $0.10 \mathrm{mmol} / \mathrm{L}$ pyrite precipitation, except for $2-\mathrm{d}(0.16 \mathrm{mmol} / \mathrm{L})$ and $3-\mathrm{d}(2.06 \mathrm{mmol} / \mathrm{L})$, and less than 0.10 $\mathrm{mmol} / \mathrm{L}$ celestite mass transfer, except for models 1 -a, 2 -a, 3 -a, and 3 -d (celestite dissolution of $0.12,0.30,0.21$, and 0.39 mmol/L, respectively) and model 2-b $(0.22 \mathrm{mmol} / \mathrm{L}$ celestite precipitation) $]$

\begin{tabular}{|c|c|c|c|c|c|c|c|c|c|c|c|c|c|c|c|}
\hline \multirow{2}{*}{$\begin{array}{l}\text { Sec- } \\
\text { tion }\end{array}$} & \multirow{2}{*}{$\begin{array}{c}\text { Initial } \\
\text { well }\end{array}$} & \multirow{2}{*}{$\begin{array}{l}\text { Final } \\
\text { well }\end{array}$} & \multirow{2}{*}{ gyp } & \multirow{2}{*}{ dol } & \multirow{2}{*}{ cal } & \multirow{2}{*}{$\mathrm{CH}_{2} \mathrm{O}$} & \multirow{2}{*}{$\mathrm{CO}_{2}$} & \multicolumn{3}{|c|}{$\delta^{34} \mathrm{~S}$ (total S), per mil } & \multicolumn{3}{|c|}{$\delta^{13} \mathrm{C}$ (total C), per mil } & \multicolumn{2}{|c|}{${ }^{87} \mathrm{Sr} /{ }^{86} \mathrm{Sr}$} \\
\hline & & & & & & & & gyp & calc $^{1}$ & obs & dol & calc $^{2}$ & obs & calc & obs \\
\hline \multicolumn{3}{|c|}{ Flow Path 1: } & & & & & & & & & & & & & \\
\hline $1-\mathrm{a}$ & 58 & 43 & 2.96 & 1.32 & -2.48 & 0.15 & -0.08 & 22 & 22.9 & 23.0 & -4 & -8.5 & -8.8 & 0.70785 & 0.70782 \\
\hline $1-b^{3,4}$ & 43 & 48 & 4.77 & 1.70 & -3.58 & -- & -0.31 & 24 & 23.6 & 23.2 & -5 & -7.5 & -7.7 & 0.70782 & 0.70781 \\
\hline \multicolumn{16}{|c|}{ Flow Path 2: } \\
\hline $2-\mathrm{a}$ & 60 & 53 & 0.53 & 0.29 & -0.67 & 0.12 & 0.32 & 25 & 23.8 & 24.1 & 0 & -10.2 & -9.9 & 0.70780 & 0.70775 \\
\hline $2-b$ & 53 & 46 & 1.53 & 0.99 & -1.69 & -- & -0.15 & 22 & 25.1 & 25.0 & -5 & -8.3 & -8.6 & 0.70775 & 0.70778 \\
\hline $2-c$ & 46 & 24 & 6.11 & 1.90 & -4.55 & 0.46 & -- & 22 & 23.9 & 23.7 & -4 & -8.5 & -8.3 & 0.70778 & 0.70783 \\
\hline $2-d$ & 24 & 21 & 9.74 & 2.03 & -5.00 & 0.62 & -- & 20 & 22.9 & 23.0 & 2 & -5.3 & -5.0 & 0.70783 & 0.70779 \\
\hline $2-e^{3,4}$ & 21 & 36 & 0.92 & 0.51 & -0.92 & 0.19 & -- & 22 & 23.0 & 22.9 & -4 & -6.4 & -6.7 & 0.70780 & 0.70784 \\
\hline \multicolumn{16}{|c|}{ Flow Path 3: } \\
\hline $3-\mathrm{a}$ & 62 & 55 & 1.90 & 1.19 & -1.85 & 0.12 & 1.05 & 24 & ${ }^{5} 24.3$ & 23.8 & 2 & -8.8 & -6.6 & - & -- \\
\hline $3-b$ & 55 & 28 & 1.94 & 0.91 & -1.87 & -- & $<-0.01$ & 24 & 24.2 & 23.8 & -3 & -6.3 & -6.4 & - & - \\
\hline $3-c^{3,4}$ & 28 & 7 & 0.45 & -0.07 & -0.15 & -- & -- & 24 & 23.6 & 24.0 & -- & -6.6 & -6.5 & -- & - \\
\hline $3-d^{3,4}$ & 7 & 3 & -- & -2.23 & 0.40 & 7.81 & -3.24 & -. & 31.7 & 21.9 & -- & -21.2 & -7.4 & -- & - \\
\hline
\end{tabular}

${ }^{1}$ Using $\delta^{34} \mathrm{~S}$ of gypsum shown in previous column.

${ }^{2}$ Using $\delta^{13} \mathrm{C}$ of dolomite shown in previous column.

${ }^{3}$ Model has saltwater mixing; water from well 2 used as saltwater end member (fractions of saltwater are: 0.012 for 1-b; 0.016 for 2-e; 0.020 for 3-c; 0.419 for 3-d).

${ }^{4}$ Model has Ca/Na exchange (-0.20 mmol/L for 1-b, $-0.42 \mathrm{mmol} / \mathrm{L}$ for $2-\mathrm{e}, 0.52 \mathrm{mmol} / \mathrm{L}$ for $3-\mathrm{c}$, and $-4.04 \mathrm{mmol} / \mathrm{L}$ for $\left.3-\mathrm{e}\right)$.

${ }^{5}$ Initial water had insufficient sulfate for $\delta^{34} \mathrm{~S}_{\text {sulfate }}$ analysis; $\delta^{34} \mathrm{~S}_{\text {sulfate }}$ for initial water (well 62) assumed to be 54.5 per mil, using fractionation factor from nearest shallow Upper Floridan aquifer water (well 60). 


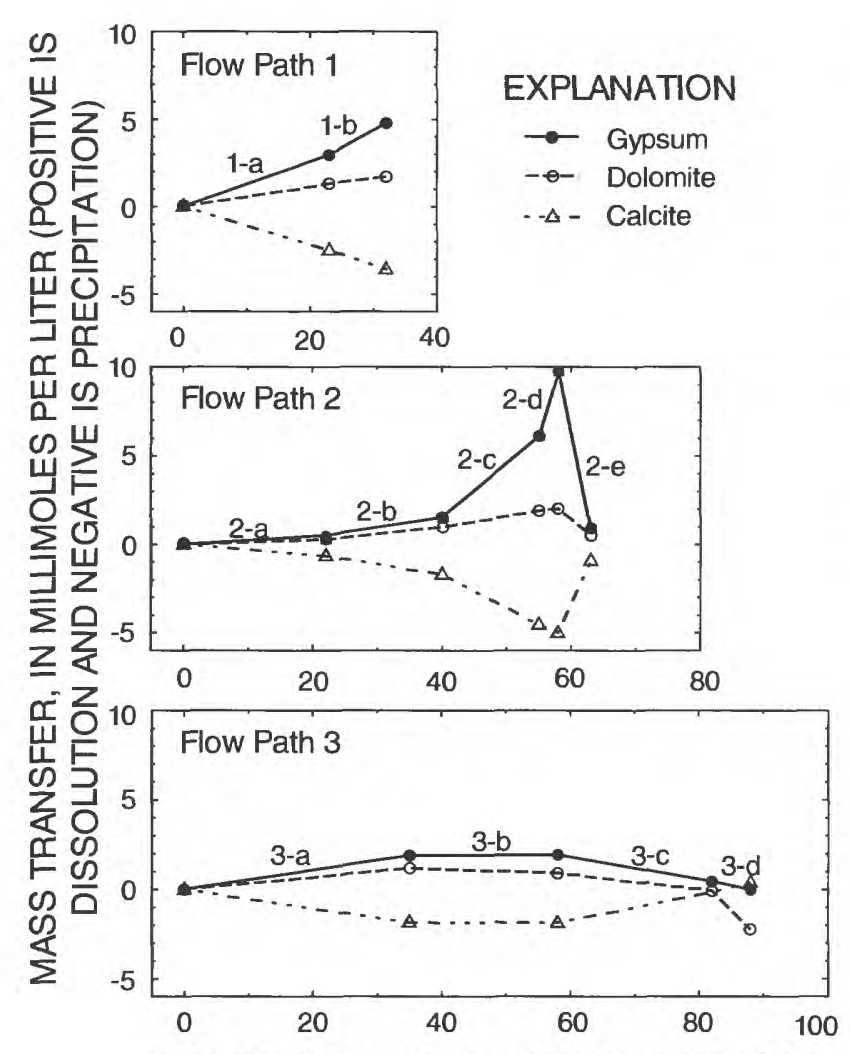

DISTANCE ALONG FLOW PATH, IN MILES (Mass transfer between sections of flow path plotted at the downgradient well)

Figure 27. Gypsum, dolomite, and calcite mass transfer computed with NETPATH between sections of flow paths, representing reactions in water from the shallowest sampling interval in the Upper Floridan aquifer. (Locations of flow paths shown in figure $5 \mathrm{~b}$.)

greatest amount of mass transfer was computed in a relatively short lateral distance (about 10 miles) near the end of the path (sections 2-c and 2-d), before the saltwater mixing zone. Recharge conditions occur for most of the upgradient part of flow path 2, with the final well for section 2-b near the transition between recharge and discharge conditions; the rest of the flow path is within the aquifer discharge area. The amount of mass transfer for reactions in the furthest downgradient site (section 2-e), which is in the saltwater mixing zone, was much less than in previous sections of the flow path. This includes an order of magnitude less gypsum dissolution. The amount of dedolomitization reactions for flow path 3 was much less than for the other flow paths, with the majority of the masstransfer reactions occurring in the central Peace River Basin. All sections of the flow path, other than the first (3-a), are in the discharge area. In the last section of this flow path, dedolomitization reactions were not computed by the model.

Isotopic data generally support the modeled reactions (table 6). Computed $\delta^{34} \mathrm{~S}$ values for the final waters were often close to the observed values when assuming a uniform $\delta^{34} S_{\text {gypsum }}$ value of 24 per mil (near the median value of gypsum in the middle confining unit; table 2). When a variable $\delta^{34} S_{\text {gypsum }}$ composition was used, within the range of measured values ( 20 to 25 per mil in the middle confining unit), observed and computed $\delta^{34} \mathrm{~S}$ values matched for almost all models (table 6). The isotopic data support the hypothesis that gypsum dissolution is the source of sulfate in the aquifer, and that pyrite precipitation is not an important sink for sulfur.

Calculated and observed $\delta^{13} \mathrm{C}$ values were usually within 0.5 per mil when assuming a value for $\delta^{13} \mathrm{C}_{\text {dolomite }}$ between 0 and -5 per mil (table 6). (In contrast, calculated values were often heavier than observed values when using $\delta^{13} C_{\text {dolomite }}$ of 0 per mil for all models.) Isotopically light dolomites (-2.8 to 7.5 per mil) have been observed in the Floridan aquifer system (Hanshaw and Back, 1972), although the limited analyses of dolomite for the current project were not isotopically light (table 2). Based on mass balance modeling, Plummer (1977) concluded that isotopically light dolomite (between -1.5 and -3.9 per mil) was dissolving along a regional flow path in the Upper Floridan aquifer in southwest Florida. Sacks (1996) also concluded that isotopically light dolomite was dissolving in the Upper Floridan aquifer in northwest central Florida.

Several sections of flow paths (3-a and 2-d), had calculated $\delta^{13} \mathrm{C}$ values that were lighter than observed values (table 6). For section 3 -a, an unrealistically heavy value for $\delta^{13} \mathrm{C}_{\text {dolomite }}$ would need to be used in the model ( 6.0 per mil) to have observed and calculated values match. The discrepancy between observed and calculated $\delta^{13} \mathrm{C}$ may be related to the final water being from a well with a large open hole interval. Some of the water may have originated from deeper zones in the aquifer, resulting in a heavier observed $\delta^{13} \mathrm{C}$ value. Water from a nearby well used for geochemical modeling by Plummer and others (1983) had an isotopically lighter $\delta^{13} \mathrm{C}$ value (-8.4 per mil), which may be more representative of shallow water from the Upper Floridan aquifer. For section 2$\mathrm{d}$, calculated and observed $\delta^{13} \mathrm{C}$ values matched when using an isotopically heavy dolomite (about 2 per mil, which is within the range of measured values from the 
study area; table 2). Alternative explanations for heavier $\delta^{13} \mathrm{C}$ values include methanogenesis and isotopic exchange (recrystallization) of calcite (Plummer and others, 1991; Katz and others, 1995b).

The last section of flow paths 1 (1-b) and 2 (2-e) and the last two sections of flow path 3 (3-c and 3-d) were in the saltwater mixing zone. $\mathrm{Ca} / \mathrm{Na}$ exchange was computed for all models. However, $\mathrm{Ca} / \mathrm{Na}$ exchange computed for section 3-c was in the opposite direction as the other saltwater mixing models (calcium was removed and sodium was added to solution). Exchange in the opposite direction as the other models may be plausible if regional differences exist in the areal extent and migration of the saltwater mixing zone. However, it may also indicate an unrealistic model. The model for section 3-c also computed very minor amounts dolomite precipitation $(0.07 \mathrm{mmol} / \mathrm{L})$. This is unlikely because the water is undersaturated with respect to disordered dolomite (the probable form of dolomite in the aquifer). Magnesium concentrations change by less than 2 percent between the initial and final waters. This small change falls within the range of analytical uncertainties for the determination of magnesium, and the calculated dolomite precipitation is probably an artifact of analytical uncertainties. Alternatively, this section may not be a true flow path, and the final water may have evolved from waters of different initial composition than those modeled.

For section 3-d, modeled reactions were unrealistic, illustrated by computed and observed isotopic values not matching (table 6). The model computed dolomite precipitation, calcite dissolution, and large amounts of $\mathrm{CH}_{2} \mathrm{O}$ oxidation, $\mathrm{CO}_{2}$ outgassing, and pyrite precipitation. The initial water had an elevated sulfate concentration from gypsum dissolution from upgradient sections of the flow path. Total sulfur decreased by about 15 percent between the initial and final waters. The sulfate concentration of the final water was similar to that expected for dilution of the deeper saline ground water, and the concentration was not characteristic of gypsum dissolution. Apparently this section (which is in the saltwater mixing zone) does not represent a true flow path, and the freshwater end member must have originated from a water other than upgradient Upper Floridan aquifer water. The freshwater end member for this water may be isolated from the regional ground-water flow system, perhaps recharging locally from the intermediate aquifer system.

\section{Upwelling Models}

The previous models indicate that dedolomitization reactions (gypsum and dolomite dissolution with calcite precipitation) are significant in controlling the composition of shallow water in the Upper Floridan aquifer. These reactions are controlled by dissolution of gypsum, which has not been observed in the shallow part of the aquifer. Therefore, the amount of gypsum dissolution predicted is probably not realistic. It is more likely that gypsum dissolves near the base of the aquifer. This high sulfate water subsequently moves upward to the shallower part of the aquifer in the discharge area.

Upwelling was further evaluated by rerunning the NETPATH models and allowing mixing with a deep, sulfate-rich ground water. Water from well 42 is from the deeper part of the aquifer in inland Sarasota County and represents fresh ground water that previously dissolved gypsum. This water was mixed with the upgradient water along sections of the flow paths to simulate upwelling. Reactions were modeled between the mixture of initial waters and the downgradient water. This is similar in approach to that used by Johnson (1994), except that Johnson used a simulated rather than a measured chemical and isotopic composition for the deep water. For sections of flow paths in the saltwater mixing zone, a three-way mixing model was considered between shallow Upper Floridan aquifer water, deep sulfate-rich water, and the saltwater end member (water from well 2).

Gypsum dissolution could be minimized or eliminated for models considering upwelling (table 7). This includes sections of the flow paths where significant amounts of gypsum dissolution were previously computed (table 6; fig. 27). These results indicate that upwelling of deep ground water can account for most of the mass transfer of sulfur in the shallow part of the aquifer. The amount of modeled upwelling was greatest where sulfate concentrations increase rapidly (western Sarasota County for flow paths 1 and 2; fig. 28). This upwelling is probably driven by the relatively sharp saltwater interface. Freshwater from deeper parts of the aquifer cannot move laterally because of the increased density of saline water near the coast. This deep freshwater, thus, moves upward to shallow parts of the aquifer and eventually discharges to the intermediate aquifer system in coastal areas and offshore. 
Table 7. NETPATH models between the shallowest Upper Floridan aquifer waters along the three flow paths, including upwelling of deep, sulfate-rich ground water

[Units in millimoles per liter $(\mathrm{mmol} / \mathrm{L})$ unless otherwise noted; positive mass transfer indicates dissolution or ingassing; negative mass transfer indicates precipitation or outgassing; cal, calcite; dol. dolomite; gyp, gypsum; $\delta^{34} \mathrm{~S}$, delta sulfur-34; $\delta^{13} \mathrm{C}$, delta carbon- 13 ; calc, calculated; obs, observed; --, not modeled; isotope data used in models unless otherwise specified: $\delta^{13} \mathrm{C}$ of $\mathrm{CH}_{2} \mathrm{O}$ and $\mathrm{CO}_{2}=-25.0$ per mil; $\delta^{13} \mathrm{C}$ of dolomite and calcite $=0$ per mil $($ when dissolving); $\delta^{34} \mathrm{~S}$ of gypsum $=24.0$ per mil; $\delta^{34} \mathrm{~S}$ of celestite $=26.0$ per mil (when dissolving); ${ }^{87} \mathrm{Sr} /{ }^{86} \mathrm{Sr}$ of celestite $=0.70780$; for precipitating phases, $\delta^{13} \mathrm{C}$ or $\delta^{34} \mathrm{~S}$ computed by model based on Rayleigh calculations and fractionation factors defined at the midpoint ( $\mathrm{X}=0.5$ ) between initial and final water compositions; $\delta^{13} \mathrm{C}$ (observed) based on DOC of -25.0 per mil; $\delta^{34} \mathrm{~S}$ (observed) based on measured $\delta^{34} \mathrm{~S}$ of sulfate and sulfide; all models have less than 0.10 $\mathrm{mmol} / \mathrm{L}$ goethite dissolution, except for $2-\mathrm{d}(0.26 \mathrm{mmol} / \mathrm{L})$, less than $0.10 \mathrm{mmol} / \mathrm{L}$ pyrite precipitation, except for $2-\mathrm{c}(0.10 \mathrm{mmol} / \mathrm{L})$ and $2-\mathrm{d}$ $(0.27 \mathrm{mmol} / \mathrm{L}$ ), and less than $0.10 \mathrm{mmol} / \mathrm{L}$ celestite mass transfer, except for models $1-\mathrm{a}, 2-\mathrm{a}$, and 3 -a (celestite dissolution of $0.11,0.30$, and $0.20 \mathrm{mmol} / \mathrm{L}$, respectively) and model $2-\mathrm{b}(0.20 \mathrm{mmol} / \mathrm{L}$ celestite precipitation)]

\begin{tabular}{|c|c|c|c|c|c|c|c|c|c|c|c|c|c|c|}
\hline Section & $\begin{array}{l}\text { Initial } \\
\text { well }\end{array}$ & $\begin{array}{l}\text { Final } \\
\text { well }\end{array}$ & $\begin{array}{l}\text { Fraction } \\
\text { upwelling }\end{array}$ & gур & dol & cal & $\mathrm{CH}_{2} \mathrm{O}$ & $\mathrm{CO}_{2}$ & \multicolumn{2}{|c|}{$\begin{array}{c}\delta^{34} \mathrm{~S} \text { (total S) } \\
\text { per mil }\end{array}$} & \multicolumn{2}{|c|}{$\begin{array}{c}\left.\delta^{13} \mathrm{C} \text { (total } \mathrm{C}\right) \\
\text { per mil }\end{array}$} & \multicolumn{2}{|c|}{${ }^{87} \mathrm{Sr} /{ }^{86} \mathrm{Sr}$} \\
\hline \multicolumn{15}{|c|}{ Flow Path 1: } \\
\hline $1-b^{2,3}$ & 43 & 48 & 0.349 & -- & 0.24 & -0.57 & -- & -0.40 & 23.5 & 23.2 & -7.1 & -7.7 & 0.70782 & 0.70781 \\
\hline \multicolumn{15}{|c|}{ Flow Path 2: } \\
\hline $2-a$ & 60 & 53 & 0.031 & -- & 0.11 & -0.30 & 0.11 & 0.31 & ${ }^{4} 23.8$ & 24.1 & $5-10.2$ & -9.9 & 0.70780 & 0.70775 \\
\hline $2-c$ & 46 & 24 & 0.401 & -- & 0.06 & -0.70 & 0.27 & -- & ${ }^{7} 23.2$ & 23.7 & ${ }^{8}-9.2$ & -8.3 & 0.70780 & 0.70783 \\
\hline $2-d$ & 24 & 21 & 0.754 & 2.86 & -- & -1.20 & 0.60 & -- & ${ }^{7} 23.4$ & 23.0 & $5,8-9.9$ & -5.0 & 0.70782 & 0.70779 \\
\hline $2-e$ & 21 & 36 & -- & - & -- & -- & - & -- & -- & -- & -- & -- & -- & -- \\
\hline \multicolumn{15}{|c|}{ Flow Path 3: } \\
\hline $3-\mathrm{a}$ & 62 & 55 & 0.108 & -- & 0.53 & -0.55 & 0.06 & 0.96 & ${ }^{9} 23.6$ & 23.8 & -11.5 & -6.6 & -- & - \\
\hline
\end{tabular}

${ }^{1}$ Water from well 42 used as sulfate-rich upwelling water.

${ }^{2}$ Model has saltwater mixing; water from well 2 used as saltwater end member (fractions of saltwater are: 0.012 for 1-b and 0.020 for 3-c).

${ }^{3}$ Model has $\mathrm{Ca} / \mathrm{Na}$ exchange $(-0.18 \mathrm{mmol} / \mathrm{L}$ for $1-\mathrm{b}$ and 0.53 for $3-\mathrm{c})$.

${ }^{4}$ Assuming $\delta^{34} \mathrm{~S}$ of upwelling water equal to 25 per mil.

${ }^{5} \mathrm{Using} \delta^{13} \mathrm{C}$ of $\mathrm{CH}_{2} \mathrm{O}$ and $\mathrm{CO}_{2}$ equal to -20 per mil.

${ }^{6} \mathrm{Using} \delta^{13} \mathrm{C}$ of dolomite equal to -4 per mil.

${ }^{7}$ Assuming $\delta^{34} \mathrm{~S}$ of upwelling water equal to 22 per mil.

${ }^{8}$ Assuming $\delta^{13} \mathrm{C}$ of upwelling water equal to -2 per mil.

${ }^{9}$ Initial water had insufficient sulfate for $\delta^{34} \mathrm{~S}_{\text {sulfate }}$ analysis; $\delta^{34} \mathrm{~S}_{\text {sulfate }}$ for initial water (well 62) assumed to be 54.5 per mil, using fractionation factor from nearest shallow Upper Floridan aquifer water (well 60).

For flow path 3 , significant amounts of upwelling were computed in the Peace River Basin in the middle part of the path (table 7; fig. 28). Upwelling in this areas is caused by discharging conditions associated with the river. In contrast to the other flow paths, modeled upwelling decreased toward the coast for flow path 3 . The large, dispersed saltwater mixing zone for flow path 3 is consistent with a slower freshwater flow system that has not actively flushed chloride from the aquifer from previous high sea level stands (DeHaven and Jones, 1996). This may arise because significant amounts of water from the freshwater flow system already had discharged in the Peace River Basin, and deeply circulating, regional flow paths (similar to flow paths 1 and 2 to the north) are not present.

Besides less gypsum dissolution, the upwelling models computed less dolomite dissolution and calcite precipitation (tables 7). This is consistent with the hypothesis by Budd and others (1993) and Jones and others (1993) that these reactions occur deep in the aquifer. Sacks and others (1995) also concluded that dedolomitization reactions deep in the aquifer influence the chemical composition of shallow ground water in areas of upwelling.

Modeled and observed isotopic compositions were similar for most sections of flow paths (table 7). The $\delta^{13} \mathrm{C}$ and $\delta^{34} \mathrm{~S}$ values of the deeper ground water, however, may be somewhat variable, depending upon 


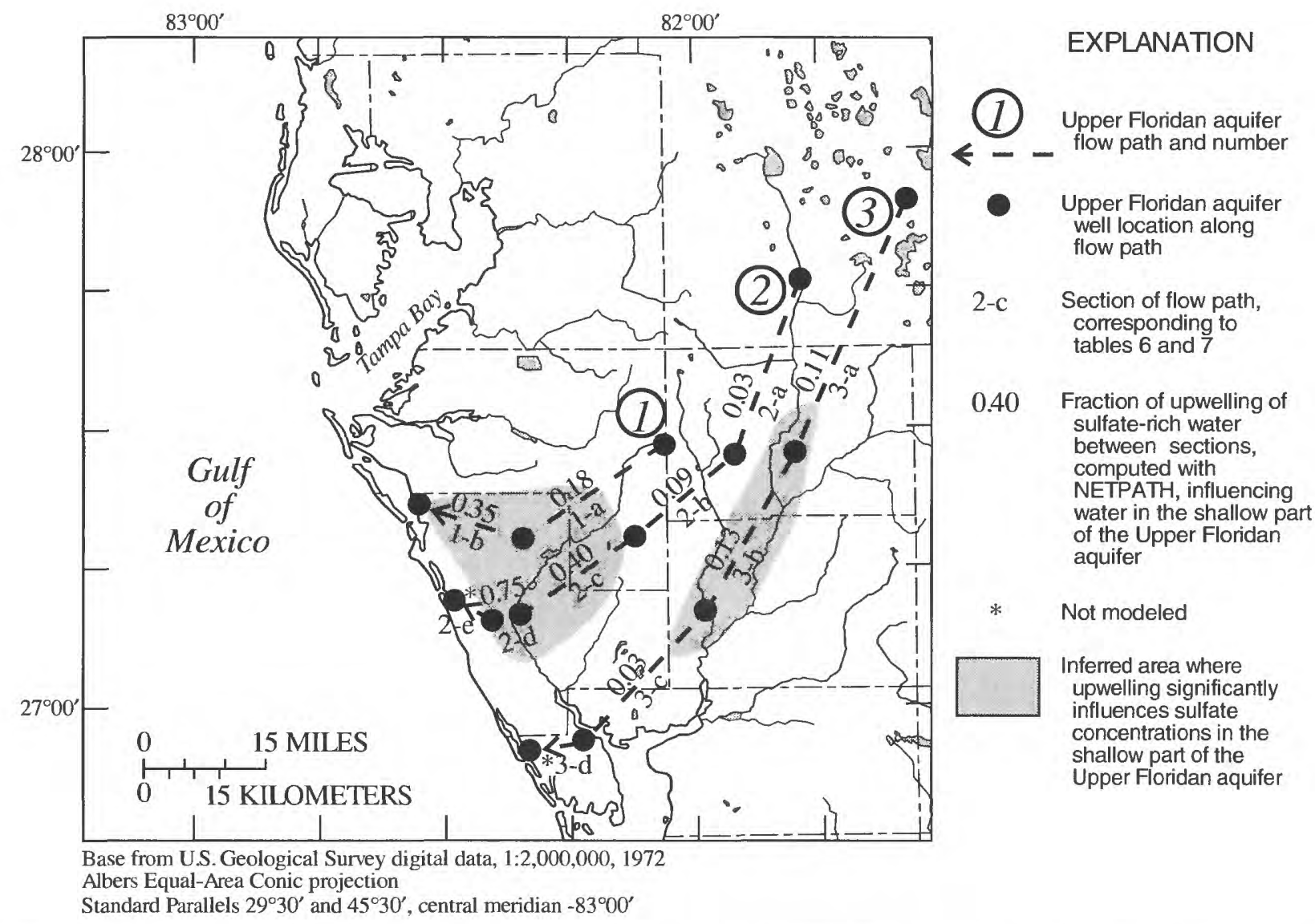

Figure 28. Amount of upwelling of sulfate-rich water computed with NETPATH along flow paths in the shallow part of the Upper Floridan aquifer, and inferred areas where upwelling significantly influences sulfate concentrations.

local heterogeneities and mineral abundance. For example, changing the upwelling $\delta^{34} \mathrm{~S}_{\text {sulfate }}$ value from 22 to 25 per mil (within the range of $\delta^{34} \mathrm{~S}$ of gypsum in the middle confining unit) results in a close match between calculated and observed values for all models (within 0.5 per mil).

For most sections of the flow paths, calculated and observed $\delta^{13} \mathrm{C}$ values were similar (within 0.5 per mil, allowing for minor variability in the $\delta^{13} \mathrm{C}$ value of dolomite or $\mathrm{CH}_{2} \mathrm{O}$; table 7). For section 3-a, computed and observed values did not match, which is probably related to the large open interval of the final well (as explained in the previous section). For sections near the end of flow path 2 (2-c and 2-d), calculated $\delta^{13} \mathrm{C}$ values were lighter than observed values. These sections represent a part of the aquifer with significant amounts of upwelling at the end of a long, deeply circulating flow path. Methanogenesis could explain the heavier $\delta^{13} \mathrm{C}$ values in the ground water (although methane was not analyzed). Alternatively, isotopic exchange (or recrystallization) of cal- cite could result in enrichment of $\delta^{13} \mathrm{C}$ in the final water (Plummer and others, 1991; Katz and others, 1995b). Johnson (1994) hypothesized that organic sulfur was responsible for the increased sulfate concentrations in this part of the aquifer, which would result in isotopically lighter $\delta^{13} \mathrm{C}$ and $\delta^{34} \mathrm{~S}$ values. However, the isotopically heavy $\delta^{13} \mathrm{C}$ observed in the ground water at the end of this flow path and $\delta^{34} \mathrm{~S}$ values in the range of gypsum preclude organic sulfur as the source of significant amounts of sulfate or carbon in this part of the aquifer.

For the last section of flow paths 2 and 3 (sections 2-e and 3-d), upwelling was not modeled. For section 2-e, the sulfate-rich upwelling water and the shallow upgradient water had the same sulfate concentration $(1,700 \mathrm{mg} / \mathrm{L})$ and very similar chemical and isotopic compositions (see appendix). Thus, the shallow water already was influenced by upwelling. The minimal amount of gypsum dissolution indicated in the model in table 6 could be from minor amounts of additional upwelling. The computed gypsum dissolu- 
tion also may be related to analytical uncertainties in the determination of sulfate (the difference between sulfate concentrations in the initial and final waters was less than 5 percent). For section $3-d$, it was previously determined that the final water was not part of the regional flow path, and sulfate in the downgradient water was not indicative of gypsum dissolution or upwelling of sulfate-rich water.

\section{SUMMARY AND CONCLUSIONS}

In southwest Florida, sulfate concentrations in the Upper Floridan aquifer and overlying intermediate aquifer system are often above the drinking water standard $(250 \mathrm{mg} / \mathrm{L})$, particularly in coastal areas. Possible sulfate sources include gypsum from the deeper part of the Upper Floridan aquifer or the middle confining unit, saltwater in the aquifer, and saline waters from the middle confining unit and Lower Floridan aquifer. The sources of sulfate and geochemical processes controlling ground-water composition were evaluated in the Peace and Myakka River Basins and adjacent coastal areas of southwest Florida. Water samples were collected from 63 wells finished at different depth intervals of the Upper Floridan aquifer and intermediate aquifer system at about 25 separate locations. Sampling, detailed analysis, and geochemical modeling focused along three flow paths based on the potentiometric surface of the Upper Floridan aquifer for predevelopment conditions. Ground water was analyzed for major ions, selected trace constituents, DOC, and stable isotopes $\left(\delta \mathrm{D}, \delta^{18} \mathrm{O}, \delta^{13} \mathrm{C}\right.$ of inorganic carbon, and $\delta^{34} \mathrm{~S}$ of sulfate and sulfide); the ratio of strontium- 87 to strontium- 86 was analyzed for waters along one of the flow paths.

In inland areas, dedolomitization reactions (gypsum and dolomite dissolution and calcite precipitation) control the chemical composition of water in the Upper Floridan aquifer. This is evidenced by concurrent increases in sulfate, calcium and magnesium concentrations along the flow paths, with calcium concentrations lower than expected for gypsum dissolution. Sulfate concentrations typically increase with depth, whereas chloride concentrations remain low, which is consistent with freshwater dissolving gypsum deep in the aquifer. In western Sarasota County, sulfate concentrations are high in both shallow and deep parts of the aquifer, but chloride concentrations increase with depth because of saltwater mixing. In this area, sulfate is in excess of conserva- tive saltwater mixing because gypsum dissolution contributes sulfate to the freshwater end member.

Most saline waters in the aquifer are not significantly enriched in sulfate relative to conservative saltwater mixing, indicating that this water dissolved much less gypsum than the fresher water in the aquifer. This is consistent with a shallow seawater source rather than saline water from the underlying middle confining unit or Lower Floridan aquifer. Calcium is enriched in these saline waters and may indicate ion exchange or dolomitization reactions are important.

In the overlying intermediate aquifer system, sulfate concentrations were usually lower and chloride concentration higher than in the Upper Floridan aquifer. The chemical composition of water in the intermediate aquifer system is controlled by differences in extent of reactions with aquifer minerals, upward leakage from the Upper Floridan aquifer, and saltwater mixing. In inland areas, waters from the intermediate aquifer system usually were bicarbonate-dominated or of mixed-ion type, with relatively low sulfate concentrations (less than $250 \mathrm{mg} / \mathrm{L}$ ). These waters differed by the extent of carbonate mineral dissolution, which is probably related to differences in lithology and the amount of $\mathrm{CO}_{2}$ generated by microbial reactions. In coastal Sarasota County and in isolated inland areas, waters from the intermediate aquifer system had high sulfate concentrations characteristic of dedolomitization waters from the underlying Upper Floridan aquifer. These waters are influenced by upward leakage from the Upper Floridan aquifer, which may be enhanced locally by pumping or interconnection of wells to both aquifer. In western Charlotte County, the waters are dominated by sodium and chloride, consistent with saltwater mixing. These waters are a mixture of bicarbonate-dominated waters and saltwater, rather than dedolomitization waters and saltwater, indicating minimal discharge of high-sulfate waters from the Upper Floridan aquifer in this area.

The $\delta \mathrm{D}$ and $\delta^{18} \mathrm{O}$ composition of water from the Upper Floridan aquifer is isotopically lightest in the upgradient recharge area and heavier in downgradient parts of aquifer. The heavier, downgradient waters, which are not in the saltwater mixing zone, probably are reflective of climatic conditions at the time of recharge that differed from modern day conditions. The isotopically heaviest waters are saline waters with seawater-like compositions. The composition of waters from the saltwater mixing zone plot along a mixing line between the composition of these saline 
waters and the heavier downgradient waters. Waters in the saltwater mixing zone in the intermediate aquifer system follow this same mixing trend. However, inland waters from the intermediate aquifer system that have elevated chloride concentrations are more enriched in $\delta \mathrm{D}$ and $\delta^{18} \mathrm{O}$ than can be explained by saltwater mixing. These waters may have undergone evaporation prior to recharge.

The extent of dedolomitization reactions in freshwater parts of the Upper Floridan aquifer influences the $\delta^{13} \mathrm{C}$ composition of inorganic carbon in water, with values becoming heavier in a downgradient direction. Saline waters have isotopically lighter $\delta^{13} \mathrm{C}$ values and may be influenced by dolomitization reactions. Waters from the intermediate aquifer system that are characteristic of upward leakage from Upper Floridan aquifer are more enriched in $\delta^{13} \mathrm{C}$ than other waters from the aquifer system, which is consistent with dedolomitization reactions in the underlying Upper Floridan aquifer. Waters that are isotopically lighter from the intermediate aquifer system may be related to greater extent of microbial oxidation of organic matter or dissolution of isotopically lighter carbonate minerals.

Sulfur isotope data confirm that gypsum dissolution is the source of sulfate for high sulfate, low chloride waters in the Upper Floridan aquifer. Values of $\delta^{34} S_{\text {sulfate }}$ for these waters are within the range of values for gypsum from the middle confining unit. Waters with lower sulfate concentrations usually had heavier $\delta^{34} S_{\text {sulfate }}$ values, consistent with a greater amount of sulfate in the water being reduced to sulfide through microbial sulfate reduction. Saline waters from the Upper Floridan aquifer had sulfur isotope compositions similar to modern seawater (about 21 per mil), and have not been influenced by significant amounts of gypsum dissolution. In the intermediate aquifer system, $\delta^{34} \mathrm{~S}_{\text {sulfate }}$ values commonly were isotopically lighter than gypsum, and may indicate the oxidation of pyrite or organic sulfur. Waters from the intermediate aquifer system with high sulfate concentrations had $\delta^{34} S$ values within the range of values for gypsum, which is consistent with upward leakage of high sulfate water from the Upper Floridan aquifer that previously dissolved gypsum.

Interpretation of strontium isotope data was complicated by multiple strontium sources, reactions of water with rocks which underwent diagenesis, and complex ground-water flow paths. In the Upper Floridan aquifer, strontium concentrations apparently are controlled by celestite $\left(\mathrm{SrSO}_{4}\right)$ dissolution in upgradient parts of the flow paths and trace quantities in gypsum in downgradient parts of the aquifer. Both strontium sources apparently have ${ }^{87} \mathrm{Sr} /{ }^{86} \mathrm{Sr}$ ratios in the range of Eocene age seawater. Saline waters with a seawater-type composition had ${ }^{87} \mathrm{Sr} /{ }^{86} \mathrm{Sr}$ ratios in the range of Oligocene age seawater, indicating mixing of strontium from relatively recent seawater and from aquifer minerals in older host rocks. The most upgradient water in the intermediate aquifer system had ${ }^{87} \mathrm{Sr} /{ }^{86} \mathrm{Sr}$ ratio in the range of ratios for Miocene age seawater, consistent with Miocene-age host rock. Downgradient, near the coast, water from deeper parts of the aquifer system had ${ }^{87} \mathrm{Sr} /{ }^{86} \mathrm{Sr}$ ratios in the range of ratios for Eocene seawater. This is consistent with upward leakage of water from the Upper Floridan aquifer that dissolved gypsum of Eocene age. In shallower zones, ${ }^{87} \mathrm{Sr} /{ }^{86} \mathrm{Sr}$ ratios were in the range of ratios for seawater during the Oligocene, which indicates multiple strontium sources of Eocene-age gypsum and Miocene age minerals from the host rock.

Geochemical mass-balance modeling was used to further evaluate reactions occurring in the shallowest part of the Upper Floridan aquifer along the three flow paths. Modeling results confirm that dedolomitization reactions (gypsum and dolomite dissolution and calcite precipitation) control the composition of the ground water. However, the amount of reactions varies significantly between sections of the flow paths and between individual flow paths. The greatest amount of gypsum dissolution was computed for sections of flow paths in western Sarasota County. Computed and measured $\delta^{34} \mathrm{~S}$ values generally matched when the $\delta^{34} S$ of gypsum ranged between 20 and 25 per mil, which is in the range of measured values for gypsum in the middle confining unit.

Dedolomitization reactions are driven by dissolution of gypsum, which occurs deeper in the aquifer than open intervals of sampled wells. Upwelling was modeled to test whether mixing with sulfate-rich water from deeper in the aquifer could explain the increases in sulfate along sections of the flow paths. Results indicate that upwelling can explain most of the mass transfer of sulfur along sections of flow paths, and gypsum does not need to dissolve in the shallow part of the aquifer, where it has not been observed. In addition to less gypsum dissolution, these upwelling models had less dolomite dissolution and calcite precipitation. Areas where significant amounts of upwelling were modeled are in discharge areas of the 
Upper Floridan aquifer, where heads increase with depth making upward flow likely. The isotopic composition of the upwelling water may vary slightly in the study area, and additional reactions involving carbon may be occurring in some locations (recrystallization of calcite or methanogenesis).

Deeply circulating ground-water flow paths apparently control the high sulfate concentrations in the shallow part of the Upper Floridan aquifer in western Sarasota County. In the recharge area, water moves downward to deep parts of the aquifer and dissolves gypsum. This dissolution occurs within the freshwater flow system, rather than as diffusion or upward leakage of saline water from the middle confining unit or the Lower Floridan aquifer. Downgradient, this sulfate-rich water moves upward to shallower parts of the aquifer and into the overlying intermediate aquifer system, prior to the saltwater mixing zone. In the vicinity of the Peace River, higher sulfate concentrations are caused by upwelling because of discharging conditions in the Upper Floridan aquifer. This discharge probably causes less freshwater to move toward the coast, and flow paths may not be as deep as in western Sarasota County, where sulfate concentrations are much higher. The freshwater end member for waters in the saltwater mixing zone in coastal Charlotte County is not upgradient water from the Upper Floridan aquifer that dissolved gypsum.

Instead, these waters appear to be isolated from the regional freshwater flow system and may be part of a more localized flow system, with relict seawater from a past inundation.

\section{REFERENCES}

Applin, P.L., and Applin, E.R., 1965, The Comanche Series and associated rocks in the subsurface in central and south Florida: U.S. Geological Survey Professional Paper 447, $84 \mathrm{p}$.

Aucott, W.R., 1988, Areal variation in recharge to and discharge from the Floridan aquifer system in Florida: U.S. Geological Survey Water-Resources Investigations Report 88-4057, 1 sheet.

Back, William, and Hanshaw, B.B., 1970, Comparison of chemical hydrogeology of the carbonate peninsulas of Florida and Yucatan: Journal of Hydrology, v. 10, p. 330-368.

Ball, J.W., and Nordstrom, D.K., 1991, User's manual for WATEQ4F, with revised thermodynamic data base and test cases for calculating speciation of major, trace, and redox elements in natural water: U.S. Geological Survey Open-File Report 91-183, 189 p.

Barr, G.L., 1996, Hydrogeology of the surficial and intermediate aquifer systems in Sarasota and adjacent Counties, Florida: U.S. Geological Survey Water Resources Investigations Report 96-4063.

Bennett, P., 1991, Quartz dissolution in organic-rich aqueous solutions: Geochimica Cosmochimica Acta, v. 5, p. 1781-1797.

Broska, J.C., and Knochenmus, L.A.,1996, Assessment of the hydrogeology and water quality in a near-shore wellfield, Sarasota, Florida: U.S. Geological Survey Water-Resources Investigations Report 96-4036, 64 p.

Buchardt, B. and Fritz, P., 1980, Environmental isotopes as environmental and climatological indicators, in Fritz, P. and Fontes, J.C., eds., Handbook of Environmental Isotope Geochemistry: Elsevier Scientific Publishing Company, Amsterdam, p. 473-504.

Budd, D.A., Hammes, Ursula, and Vacher, H.L., 1993, Calcite cementation in the Upper Floridan aquifer: A modern example for confined-aquifer cementation models?: Geology, v. 21, p. 33-36.

Busby, J.F., Plummer, L.N., Lee, R.W., and Hanshaw, B.B., 1991, Geochemical evolution of water in the Madison aquifer in parts of Montana, South Dakota, and Wyoming: U.S. Geological Survey Professional Paper 1273-F, $89 \mathrm{p}$.

Bush, P.W., and Johnston, R.H., 1988, Ground-water hydraulics, regional flow, and ground-water development of the Floridan aquifer system in Florida and in parts of Georgia, South Carolina, and Alabama: U.S. Geological Survey Professional Paper 1403-C, $80 \mathrm{p}$.

Cander, H.S., 1991, Dolomitization and water-rock interaction in the middle Eocene Avon Park Formation, Floridan aquifer: Ph.D. Dissertation, The University of Texas at Austin, $172 \mathrm{p}$.

Chapelle, F.H., 1993, Ground-water microbiology and geochemistry: John Wiley and Sons, Inc., New York, $424 \mathrm{p}$.

Chen, C.S., 1965, The regional lithostratigraphic analysis of Paleocene and Eocene rocks of Florida: Florida Geological Survey Bulletin 45, 105 p.

Claypool, G.E., Holser, W.T., Kaplan, I.R., Sakai, H., and Zak, I., 1980, The age curves of sulfur and oxygen isotopes in marine sulfate and their mutual interpretation: Chemical Geology, v. 27, p. 199-260.

Cook, D.J., Randazzo, A.F., and Sprinkle, C.L., 1985, Authigenic fluorite in dolomitic rocks of the Floridan aquifer: Geology, v. 13, p. 390-391.

Covington, J.M, 1993, Neogene nannofossils of Florida, in Sullo, V.A. and others, eds., The Neogene of Florida and adjacent regions: Florida Geological Survey Special Publication 37, $112 \mathrm{p}$. 
Craig, Harmon, 1961, Standard for reporting concentrations of deuterium and oxygen-18 in natural water: Science, v. 133 , p. $1833-1834$.

Crowder, R.E., Paillet, F.L., and Hess, A.E., 1994, High resolution flowmeter logging - a unique combination of borehole geophysics and hydraulics; Part I. Flowmeter techniques and equipment development: Proceedings of the Symposium on the Application of Geophysics to Environmental and Engineering Problems, March 26-30, 1994, Boston, Mass., Environmental and Engineering Geophysical Society, p. 361-380.

DeHaven, E.C., and Jones, G.W., 1996, Origin of chlorides in Floridan aquifer ground water in the southern wateruse caution area: Ambient Ground-Water Quality Monitoring Program, Southwest Florida Water Management District, Brooksville, Fla., 26 p.

DePaolo, D.J,. and Ingram, B.L., 1985, High-resolution stratigraphy with strontium isotopes: Science, v. 227, p. 938-941.

Drever, J.I., 1982, The geochemistry of natural waters: Prentice-Hall, Inc., Englewood Cliffs, N.J., 388 p.

Duerr, A.D., and Enos, G.M., 1991, Hydrogeology of the intermediate aquifer system and Upper Floridan aquifer, Hardee and De Soto Counties, Florida: U.S. Geological Survey Water-Resources Investigations Report 90-4104, 46 p.

Duerr, A.D., and Wolansky, R.M., 1986, Hydrogeology of the surficial and intermediate aquifers of central Sarasota County, Florida: U.S. Geological Survey Water-Resources Investigations Report 86-4068, 48 p.

Elderfield, H., 1986, Strontium isotope stratigraphy: Paleogeography, Paleoclimatology, Paleoecology, v. 57 , p. 71-90.

Fishman, M.J., and Friedman, L.C., eds., 1989, Methods for determination of inorganic substances in water and flavial sediment: U.S. Geological Survey Techniques of Water-Resources Investigations, book 5, chap. A1, $545 \mathrm{p}$.

Florida Department of State, 1993, Rules of the Department of Environmental Regulation, Drinking water standards, monitoring, and reporting: Florida Administrative Code, Chapter 17-550, p. 13-22.

Gilboy, A.E., 1985, Hydrogeology of the Southwest Florida Water Management District: Southwest Florida Water Management District Report, 18 p.

Hach Company, 1989, Water analysis handbook: Loveland, Colo., $689 \mathrm{p}$.

Hammett, K.M., 1990, Land use, water use, streamflow characteristics, and water-quality characteristics of the Charlotte Harbor inflow area, Florida: U.S. Geological Survey Water-Supply Paper 2359-A, 64 p.
Hanshaw, B.B., and Back, William, 1972, On the origin of dolomites in the Tertiary aquifer of Florida, in Puri, H.S., ed., Proceeding of the Seventh Forum on Geology of Industrial Minerals: Florida Bureau of Geology Special Publication no. 17, p. 139-153.

Hanshaw, B.B., and Back, William, 1979, Major geochemical processes in the evolution of carbonateaquifer systems: Journal of Hydrology, v. 43, p. 287312.

Hanshaw, B.B., Back, William, and Deike, R.G., 1971, A geochemical hypothesis for dolomitization by ground water: Economic Geology, v. 66, p. 710-724.

Hardie, L.A., 1987, Dolomitization: a critical view of some current views: Journal of Sedimentary Petrology, v. 57, p. $166-183$.

Hem, J.D., 1989, Study and interpretation of the chemical characteristics of natural water (3rd ed.): U.S. Geological Survey Water-Supply Paper 2254, 263 p.

Hess, A.E., 1990, Thermal pulse flowmeter for measuring slow water velocities in boreholes: U.S. Geological Survey Open-File Report 87-121, 70 p.

Hess, A.E., and Paillet, F.L., 1990, Application of the thermal-pulse flowmeter in the hydraulic characterization of fractured rocks: Geophysical Applications for Geotechnical Investigations, American Society for Testing and Materials, Standard Technical Publication 1101, p. 99-112.

Hess, J., Bender, M.L., and Schilling, J.G., 1986, Seawater ${ }^{87} \mathrm{Sr} /{ }^{86} \mathrm{Sr}$ evolution from Cretaceous to present: Science, v. 231, p. 979-984.

Hickey, J.J., 1990, An assessment of flow of the variablesalinity ground water in the middle confining unit of the Floridan aquifer system, west-central Florida: U.S. Geological Survey Water-Resources Investigations Report 89-4142, 13 p.

Hobbie, A.E., 1993, Chemical variation in groundwater composition with depth through a lithologically heterogeneous carbonate aquifer system: M.S. Thesis, University of Virginia, Charlottesville, $170 \mathrm{p}$.

Hsu, K.J., 1963, Solubility of dolomite and composition of Florida ground waters: Journal of Hydrology, v. 1, p. 288-310.

Hutchinson, C.B., 1984, Hydrogeology of the Verna wellfield area and management alternatives for improving yield and quality of water, Sarasota County, Florida: U.S. Geological Survey Water-Resources Investigations Report 84-4016, 26 p.

Hutchinson, C.B., 1992, Assessment of hydrogeologic conditions with emphasis on water quality and wastewater injection, southwest Sarasota and west Charlotte Counties, Florida: U.S. Geological Survey Water-Supply Paper 2371, 74 p. 
HydroGeoLogic, Inc., 1994, DSTRAM-based crosssectional modeling of saltwater intrusion in the Eastern Tampa Bay Water Use Caution Area: Consultant's report to the Southwest Florida Water Management District, Brooksville, Fla., p. 4-19.

Jensen, M.L., and Nakai, N., 1961, Sources and isotopic composition of atmospheric sulfur: Science, v. 134, p. 2102-2104.

Johnson, B.C., 1994, Chemical stratification, mixing, and water-rock interaction in the Upper Floridan aquifer: M.S. Thesis, University of Colorado, Boulder, 219 p.

Jones, G.W., and Upchurch, S.B., 1993, Structural controls on ground-water quality in southwest Florida and implications for water management, in Upchurch, S.B., Moore, J.E., and Zaporozec, A., eds., Proceedings of the 10th Annual Conference of the AIH Meeting in Orlando, Florida, Nov. 3-7, 1991: American Institute of Hydrology, Minneapolis, Minn., p. 149-155.

Jones, I.C., Vacher, H.L, and Budd, D.A., 1993, Transport of calcium, magnesium, and $\mathrm{SO}_{4}$ in the Floridan aquifer, west-central Florida: implications to cementation rates: Journal of Hydrology, v. 143, p. $455-480$.

Katz, B.G., 1992, Hydrogeochemistry of the Upper Floridan aquifer, Florida: U.S. Geological Survey WaterResources Investigations Report 91-4196, 37 p.

Katz, B.G., Lee, T.M., Plummer, L.N., and Busenberg, Eurybiades, 1995a, Chemical evolution of groundwater near a sinkhole lake, northern Florida, 1. Flow patterns, age of groundwater and influence of lakewater leakage: Water Resources Research, v. 31, p. 1549-1564.

Katz, B.G., Plummer, L.N., and Busenberg, Eurybiades, Revesz, K.M., Jones, B.F., and Lee, T.M., 1995b, Chemical evolution of groundwater near a sinkhole lake, northern Florida, 2. Chemical patterns, masstransfer modeling, and rates of chemical reactions: Water Resources Research, v. 31, p. 1564-1584.

Kauffman, S.J., 1994, The geochemical effects of confining units on the groundwater evolution of a lithologically heterogeneous carbonate aquifer: M.S. Thesis, University of Virginia, Charlottesville, $113 \mathrm{p}$.

Kaufman, M.I., and Dion, N.P., 1967, Chemical character of water in the Floridan aquifer in southern Peace River Basin, Florida: Florida Bureau of Geology Map Series Report no. 27, 1 sheet.

Kohout, F.A., 1967, Ground-water flow and the geothermal regime of the Floridan Plateau, in Symposium on Geological History of the Gulf of Mexico Caribbean Antigen Basin: Gulf Coast Association of Geological Societies, Transactions, v. 17, p. 339-354.
Kohout, F.A., Henry, H.R., and Banks, J.E., 1977, Hydrogeology related to geothermal conditions of the Floridan plateau, in Smith, D.L., and Griffin, G.M., eds., The geothermal nature of the Floridan Plateau: Florida Bureau of Geology Special Publication no. 21, p. 1-39..

Krouse, H.R., 1980, Sulphur isotopes in our environment, in Fritz, P. and Fontes, J.Ch., eds., Handbook of environmental isotope geochemistry: Elsevier Scientific Publishing Co., New York, p. 227-258.

Kushnir, Jacob, 1980, The coprecipitation of strontium, magnesium, sodium, potassium, and chloride ions with gypsum, an experimental study: Geochimica et Cosmochimica Acta, v. 44, p. 1471-1482.

Law Environmental, Inc., 1989, Results of exploratory/monitor well construction and testing, Knight Trail Park: Consultant's report to the Florida Department of Environmental Regulation, file no. UC58-125241, Tallahassee, Fla.

McCartan, Lucy, Duerr, A.D., and Hawkins, R.M., 1992a, Magnesium-rich clay minerals in Tertiary carbonate rocks of southwestern Florida, in Gohn, G.S., ed., Proceedings of the 1988 U.S. Geological Survey Workshop on the Geology and Geohydrology of the Atlantic Coastal Plain: U.S. Geological Survey Circular 1059, p. 121-128.

McCartan, Lucy, Plummer, L.N., Hosterman, J.W., Busenburg, E., Dwornik, E.J., Duerr, A.D., Miller, R.L., and Kiesler, J.L, 1992b, Celestine $\left(\mathrm{SrSO}_{4}\right)$ in Hardee and De Soto Counties, Florida, in Gohn, G.S., ed., Proceedings of the 1988 U.S. Geological Survey Workshop on the Geology and Geohydrology of the Atlantic Coastal Plain: U.S. Geological Survey Circular 1059, p. 129-138.

McMahon, P.B., Vroblesky, D.A., Bradley, P.M., Chapelle, F.H., and Gulley, C.D., 1995, Evidence for enhanced mineral dissolution in organic acid-rich shallow ground water: Ground Water, v. 22, no. 2, p. 207-216.

Metz, P.A., 1995, Hydrogeology and simulated effects of ground-water withdrawals for citrus irrigation, Hardee and De Soto Counties, Florida: U.S. Geological Survey Water-Resources Investigations 83-4158, 83 p.

Metz, P.A., 1996, The potential for water-quality degradation of interconnected aquifers in west-central Florida: U.S. Geological Survey Water-Resources Investigations Report 96-4030, 54 p.

Meyers, J.B., Swart, P.K., Meyers, J.L., 1993, Geochemical evidence for groundwater behavior in an unconfined aquifer, south Florida: Journal of Hydrology, v. 148, p. 249-272.

Miller, J.A., 1986, Hydrogeologic framework of the Floridan aquifer system in Florida and parts of Georgia, South Carolina, and Alabama: U.S. Geological Survey Professional Paper 1403-B, 91 p. 
Missimer, T.M., McNeill, D.F., Ginsburg, R.N, 1994, Cenozoic record of global sea level events in the Hawthorn Group and Tamiami Formation of the Florida Platform: Geological Society of America Abstracts with Programs, v. 26, no. 7, p. A-151.

Moore, C.H., 1989, Carbonate diagenesis and porosity: Elsevier Science Publishers, B.V., Amsterdam, 338 p.

Mularoni, R.A., 1992a, Potentiometric surfaces of the intermediate aquifer system, west-central Florida, May 1992: U.S. Geological Survey Open File Report 92471,1 plate.

Mularoni, R.A., 1992b, Potentiometric surface of the Upper Floridan aquifer, west-central Florida, May 1992: U.S. Geological Survey Open File Report 92-472, 1 plate.

National Acid Deposition Program/National Trends Network, 1994, Annual data summary, Precipitation chemistry in the United States 1993: NADP/NTN, Colorado State University, Fort Collins.

Nordstrom, D.K., Plummer, L.N., Langmuir, D., Busenberg, Eurybiades., May, H.M., Jones, B.F., and Parkhurst, D.L., 1990, Revised chemical equilibrium data for major water-mineral reactions and their limitation, in Melchior, D.C., and Basset, R.L., eds., Chemical modeling of aqueous systems II: American Chemical Society Symposium Series 416, p. 398-413.

Östlund, G., 1959, Isotopic composition of sulfur in precipitation and sea-water: Tellus, v. 11, p. 478-480.

Pankow, J.F., 1991, Aquatic chemistry concepts: Lewis Publishers, Chelsea, Mich., 683 p.

Plummer, L.N., 1977, Defining reactions and mass transfer in part of the Floridan aquifer: Water Resources Research, v. 13, no. 5, p. 801-812.

Plummer, L.N., and Back, William, 1980, The mass balance approach: application to interpreting the chemical evolution of hydrologic systems: American Journal of Science, v. 280, p. 130-142.

Plummer, L.N., Busby, J.F., Lee, R.W., and Hanshaw, B.B., 1990, Geochemical modeling of the Madison aquifer in parts of Montana, Wyoming, and South Dakota: Water Resources Research, v. 26, no. 9., p. 1981-2014. Plummer, L.N., Parkhurst, D.L., Fleming, G.F., and Dunkle, S.A., 1988, A computer program incorportating the Pitzer's equations for calculations of geochemical reactions in brines: U.S. Geological Survey WaterResources Investigations Report 88-4153, 310 p.

Plummer, L.N., Parkhurst, D.L., and Thorstenson, D.C., 1983, Development of reaction models for ground water systems: Geochimica et Cosmochimica Acta, v. 47 , p. $665-686$.

Plummer, L.N., Prestemon, E.C., and Parkhurst, D.L., 1991, An interactive code (NETPATH) for modeling net geochemical reactions along a flow path: U.S. Geological Survey Water-Resources Investigations Report 91-4078, 227 p.
Plummer, L.N., Prestemon, E.C., and Parkhurst, D.L., 1994, An interactive code (NETPATH) for modeling net geochemical reactions along a flow path, version 2.0: U.S. Geological Survey Water-Resources Investigations Report 94-4169, $130 \mathrm{p}$.

Ramette, R.W., 1981, Limitations of experimental measurements in chemical equilibrium and analysis: Addison-Wesley, Reading, Mass., p. 49-82.

Randazzo, A.F., and Bloom, J.I., 1985, Mineralogical changes along the freshwater/saltwater interface of a modern aquifer: Sedimentary Geology, v. 43, p. 219239.

Randazzo, A.F., and Hickey, E.W., 1978, Dolomitization in the Floridan aquifer: American Journal of Science, v. 278 , p. $1177-1184$.

Randazzo, A.F., Koster, Mieke, Jones, D.S., and Portell, R.W., 1990, Paleoecology of shallow-marine carbonate environments, middle Eocene of peninsular Florida: Sedimentary Geology, v. 66, p. 1-11.

Rees, C.E., Jenkins, W.J., and Monster, J., 1978, The sulphur isotope geochemistry of ocean water sulphate: Geochemica Cosmochimica Acta, v. 42, p. 377-382.

Rightmire, C.T., and Hanshaw, B.B., 1973, Relationship between carbon isotope composition of soil $\mathrm{CO}_{2}$ and dissolved carbonate species in ground water: Water Resources Research, v. 9, no. 4, p. 958-967.

Rightmire, C.T., Pearson, F.J., Jr., Back, William, Rye, R.O., and Hanshaw, B.B., 1974, Distribution of sulfur isotopes in ground waters from the principal artesian aquifer of Florida and the Edwards aquifer of Texas, United States of America: Isotope Techniques in Groundwater Hydrology, v. 2, International Atomic Energy Agency, Vienna, p. 191-207.

Ryder, P.D., 1982, Digital model of predevelopment flow in the Tertiary limestone (Floridan) aquifer system in west-central Florida: U.S. Geological Survey WaterResources Investigations Report 81-54, 61 p.

Ryder, P.D., 1985, Hydrology of the Floridan aquifer system in west-central Florida: U.S. Geological Survey Professional Paper 1403-F, 63 p.

Rye, R.O., Back, William, Hanshaw, B.B., Rightmire, C.T., and Pearson, F.J. Jr., 1981, The origin and isotopic composition of dissolved sulfide in ground water from carbonate aquifers in Florida and Texas: Geochimica et Cosmochimica Acta, v. 45, p. 1941-1950.

Sacks, L.A., 1996, Geochemical and isotopic composition of ground water with emphasis on sources of sulfate in the Upper Floridan aquifer in parts of Marion, Sumter, and Citrus Counties, Florida: U.S. Geological Survey Water-Resources Investigations Report, $47 \mathrm{p}$.

Sacks, L.A., Herman, J.S., and Kauffman, S.J, 1995, Controls on high sulfate concentrations in the Upper Floridan aquifer in southwest Florida: Water Resources Research, v. 31, p. 2541-2551. 
Scott, T.M., 1988, The lithostratigraphy of the Hawthorn Group (Miocene) of Florida: Florida Geological Survey Bulletin no. 59, $148 \mathrm{p}$.

Scott, T.M., Wingard, G.L, Weedman, S.D., and Ewards, L.E., 1994, Reinterpretation of the peninsular Florida Oligocene: a multidisciplinary view: Geological Society of America Abstracts with Programs, v. 26, no. 7, p. A-151.

Sinclair, W.C., 1979, Test data from the chloride-monitor well at Sun City Center, Hillsborough County, Florida: U.S. Geological Survey Open-File Report 79-1030, $20 \mathrm{p}$.

Smith, D.L. 1982, Review of the tectonic history of the Florida basement: Tectonophysics, v. 88. p. 1-22.

Southeastern Geological Society, 1986, Hydrogeological units of Florida: Florida Bureau of Geology Special Publications no. 8, 8 p.

Southwest Florida Water Management District, 1991, Ground-water quality of the Southwest Florida Water Management District, southern region, section 2: Ambient Ground-Water Quality Monitoring Program, Southwest Florida Water Management District, Brooksville, Fla., 275 p.

Sprinkle, C.R., 1989, Geochemistry of the Floridan aquifer system in Florida and in parts of Georgia, South Carolina, and Alabama: U.S. Geological Survey Professional Paper 1403-I, 105 p.

Steinkampf, W.C., 1982, Origins and distribution of saline ground waters in the Floridan aquifer in coastal southwest Florida: U.S. Geological Survey WaterResources Investigations Report 82-4052, 34 p.
Swancar, Amy, and Hutchinson, C.B., 1995, Chemical and isotopic composition and potential for contamination of water in the Upper Floridan aquifer, west-central Florida, 1986-89: U.S. Geological Survey WaterSupply Paper 2409, 70 p.

Wilson, W.E., 1977, Ground-water resources of De Soto and Hardee Counties, Florida: Florida Bureau of Geology Report of Investigations no. 83, $102 \mathrm{p}$.

Wingard, G.L., Sugarman, P.J., Edwards, L.E., McMartan, Lucy, and Feigenson, M.D., 1993, Biostratigraphy and chronostratigraphy of the area between Sarasota and Lake Okeechobee, southern Florida - an intergrated approach: Geological Society of America Abstracts with Programs, v. 25, no. 4, p. 78.

Wolansky, R.M., 1983, Hydrogeology of the Sarasota-Port Charlotte area, Florida: U.S. Geological Survey WaterResources Investigations Report 82-4089, 48 p.

Wood, W.W., 1976, Guidelines for collection and field analysis of ground-water samples for selected unstable constituents: U.S. Geological Survey Techniques of Water-Resources Investigations, book 1, chap. D2, $24 \mathrm{p}$.

Yobbi, D.K., 1983, Trends and fluctuations in the potentiometric surface of the Floridan aquifer, westcentral Florida, 1961-80: U.S. Geological Survey Water-Resources Investigations Report 82-4086, 1 sheet. 